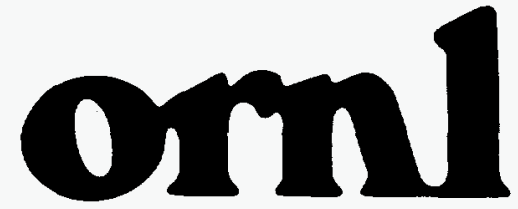

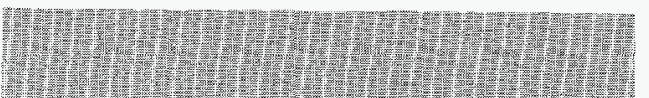

OAK RIDGE

NATIONAL

LABORATORY

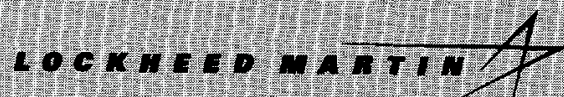

1.

13)

Wyysy
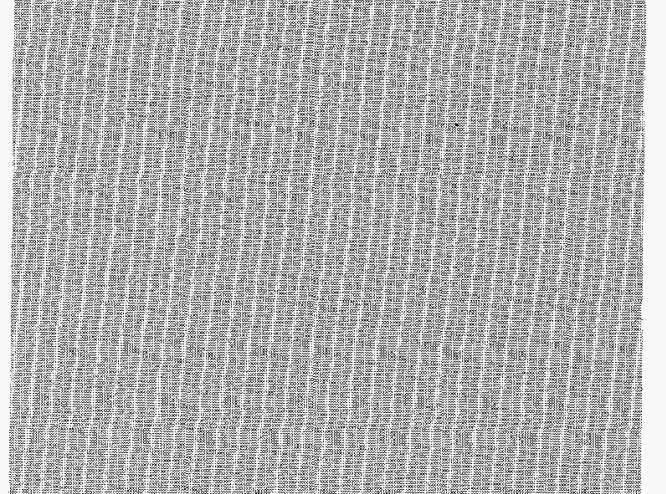

RECEIVED SEP 171997 OSTI

\section{Laboratory Tests in Support of the MSRE Reactive Gas Removal System}
J. C. Rudolph
G. D. Del Cul
J. Caja
L. M. Toth
D. F. Williams
K. S. Thomas
D. E. Clark 
This report has been reproduced directly from the best available copy.

Available to DOE and DOE contractors from the Office of Scientific and Technical Information, P. O. Box 62, Oak Ridge, TN 37831; prices available from (423) 576-8401, FTS 626-8401.

Available to the public from the National Technical Information Service, U.S. Department of Commerce, 5285 Port Royal Road, Springfield, VA 22161.

This report was prepared as an account of work sponsored by an agency of the United States Government. Neither the United States Government nor any agency thereof, nor any of their employees, makes any warranty, express or implied, or assumes any legal liability or responsibility for the accuracy, completeness, or usefulness of any information, apparatus, product, or process disclosed, or represents that its use would not infringe privately owned rights. Reference herein to any specific commercial product, process, or service by trade name, trademark, manufacturer, or otherwise, does not necessarily constitute or imply its endorsement, recommendation, or favoring by the United States Government or any agency thereof. The views and opinions of authors expressed herein do not necessarily state or reflect those of the United States Government of any agency thereof. 


\section{DISCLAIMER}

Portions of this document may be illegible electronic image products. Images are produced from the best available original document. 


\author{
Chemical Technology Division
}

\title{
LABORATORY TESTS IN SUPPORT OF THE MSRE REACTIVE GAS REMOVAL SYSTEM
}

\author{
J. C. Rudolph \\ G. D. Del Cul \\ J. Caja \\ L. M. Toth \\ D. F. Williams \\ K.S. Thomas \\ D. E. Clark
}

July 1997

\author{
Prepared by the \\ OAK RIDGE NATIONAL LABORATORY \\ Oak Ridge, Tennessee 37831-6285 \\ managed by \\ LOCKHEED MARTIN ENERGY RESEARCH CORP. \\ for the \\ U.S. DEPARTMENT OF ENERGY \\ under contract DE-AC05-96OR22464
}




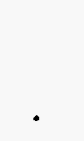




\section{TABLE OF CONTENTS}

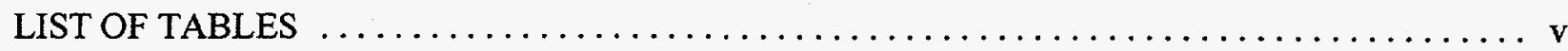

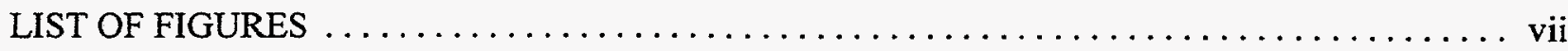

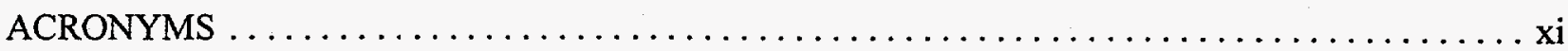

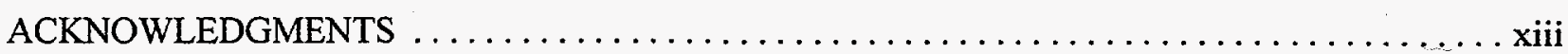

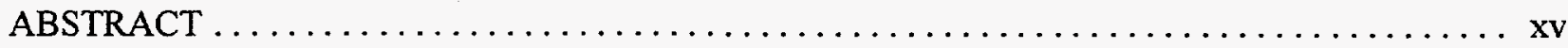

1. INTRODUCTION $\ldots \ldots \ldots \ldots \ldots \ldots \ldots \ldots \ldots \ldots \ldots \ldots \ldots \ldots \ldots \ldots \ldots \ldots \ldots \ldots \ldots \ldots \ldots$

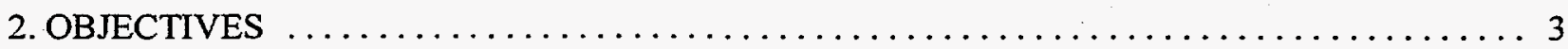

3. DESCRIPTION OF TEST APPARATUS $\ldots \ldots \ldots \ldots \ldots \ldots \ldots \ldots \ldots \ldots \ldots \ldots \ldots \ldots \ldots \ldots \ldots$

4. DESCRIPTION AND PROPERTIES OF GAS TRAPPING MATERIAL $\ldots \ldots \ldots \ldots \ldots \ldots \ldots$

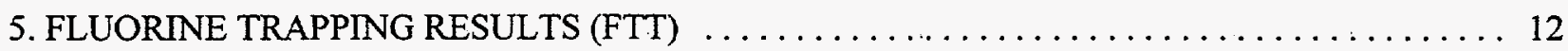

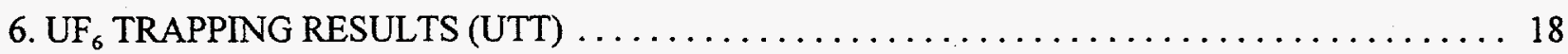

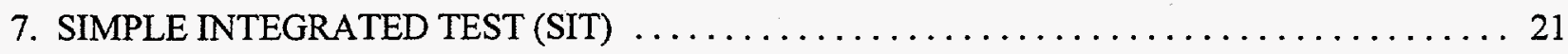

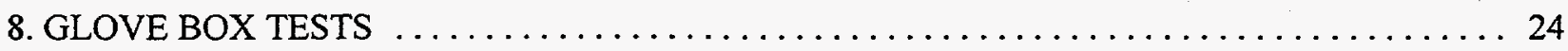

8.1 POSITIVE PRESSURE FLOW TESTS (GBTP) $\ldots \ldots \ldots \ldots \ldots \ldots \ldots \ldots \ldots \ldots, 24$

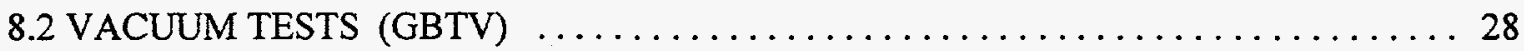

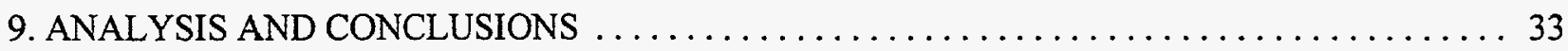

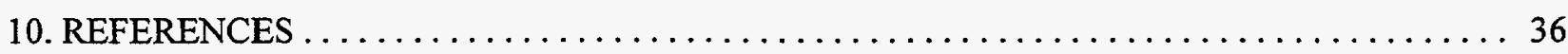

Appendix A. ADDITIONAL FIGURES $\ldots \ldots \ldots \ldots \ldots \ldots \ldots \ldots \ldots \ldots \ldots \ldots \ldots \ldots \ldots \ldots \ldots \ldots \ldots \ldots$

Appendix B. DETERMINATION OF FLUORINE LOADING PER GRAM INCREASE OF TRAP

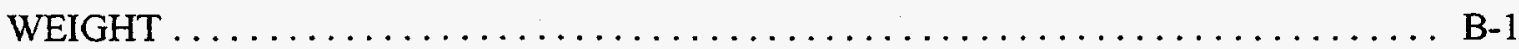

Appendix C. CALCULATION OF FLUORINE FLOW RATE BASED ON EXIT FLOWMETER READING AND HOLDING TANK PRESSURE RISE $\ldots \ldots \ldots \ldots \ldots \ldots \ldots \ldots \ldots$ C-1 



\section{LIST OF TABLES}

1. Gas analysis of two samples taken from the MSRE off-gas system $\ldots \ldots \ldots \ldots \ldots \ldots \ldots \ldots$

2. Equipment used in fluorine trapping tests (FTT) $\ldots \ldots \ldots \ldots \ldots \ldots \ldots \ldots \ldots \ldots \ldots \ldots$

3. Physical properties of NaF pellets for MSRE $\ldots \ldots \ldots \ldots \ldots \ldots \ldots \ldots \ldots \ldots \ldots \ldots \ldots$

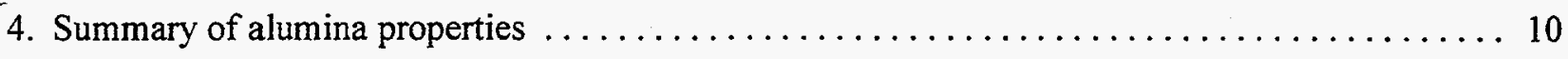

5. Summary of molecular sieve $(13 \mathrm{X})$ properties $\ldots \ldots \ldots \ldots \ldots \ldots \ldots \ldots \ldots \ldots \ldots \ldots$

6. Preparative drying results for alumina $\ldots \ldots \ldots \ldots \ldots \ldots \ldots \ldots \ldots \ldots \ldots \ldots \ldots \ldots \ldots \ldots$

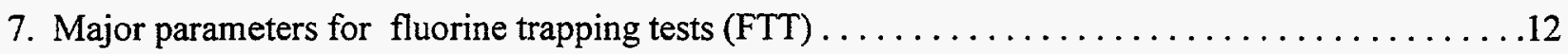

8. Peak temperatures measured in 3 -in. alumina bed. $\ldots \ldots \ldots \ldots \ldots \ldots \ldots \ldots \ldots \ldots \ldots \ldots \ldots \ldots \ldots$

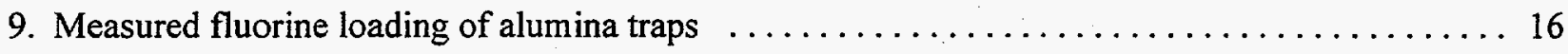

10. Characteristics of liquid collected from the alumina trap exhaust $\ldots \ldots \ldots \ldots \ldots \ldots \ldots$

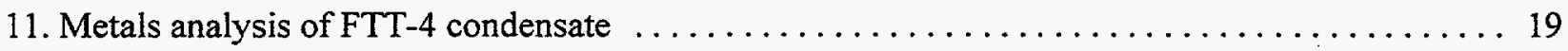

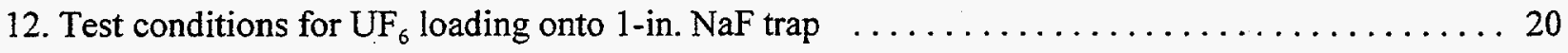

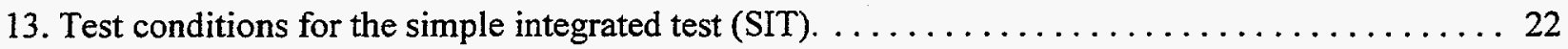

14. Parameters and results from direct loading of $\mathrm{UF}_{6}$ onto alumina $\ldots \ldots \ldots \ldots \ldots \ldots \ldots \ldots$

15. Axial positioning of thermocouples and NDA detectors on gas traps $\ldots \ldots \ldots \ldots \ldots \ldots \ldots$

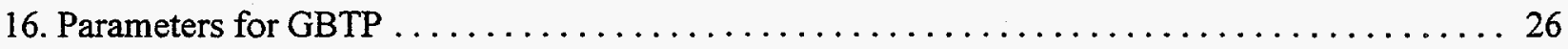

17. Maximum $\mathrm{NaF}$ and alumina temperatures and $\mathrm{UF}_{6}$ and $\mathrm{F}_{2}$ loading for GBTP........ 28

18. Metals analysis of downstream piping wash (GBTP) $\ldots \ldots \ldots \ldots \ldots \ldots \ldots \ldots \ldots \ldots \ldots$

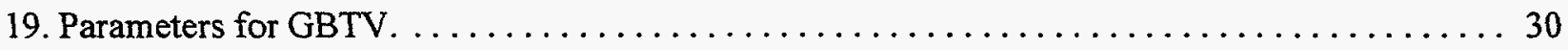

20. Maximum temperatures and $\mathrm{UF}_{6}$ and $\mathrm{F}_{2}$ loading in GBTV $\ldots \ldots \ldots \ldots \ldots \ldots \ldots \ldots \ldots$

21. Pressure measurements from GBTV $\ldots \ldots \ldots \ldots \ldots \ldots \ldots \ldots \ldots \ldots \ldots \ldots \ldots \ldots \ldots \ldots \ldots \ldots \ldots$ 



\section{LIST OF FIGURES}

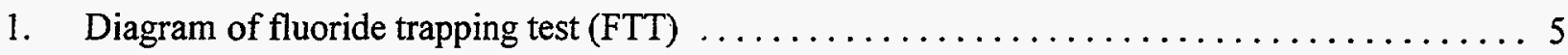

2. Diagram of $\mathrm{UF}_{6}$ trapping test (UTT) $\ldots \ldots \ldots \ldots \ldots \ldots \ldots \ldots \ldots \ldots \ldots \ldots \ldots \ldots \ldots \ldots \ldots \ldots$

3. Diagram of simple integrated trapping test $(\mathrm{SIT}) \ldots \ldots \ldots \ldots \ldots \ldots \ldots \ldots \ldots \ldots$

4. Diagram of hood portion of glove box tests under pressure (GBTP) $\ldots \ldots \ldots \ldots \ldots \ldots$

5. Diagram of hood portion of glove box tests under vacuum (GBTV) $\ldots \ldots \ldots \ldots \ldots$

6. Skin temperatures for FTT-2, $150 \mathrm{sccm}$ fluorine, 1 -in.-ID trap $\ldots \ldots \ldots \ldots \ldots \ldots \ldots$

7. Fluorine breakthrough during FTT-2, 150 sccm fluorine, 1 -in.-ID trap $\ldots \ldots \ldots \ldots \ldots$

8. Fluorine breakthrough during FTT-3F, 600 sccm fluorine, 3 -in.-ID trap $\ldots \ldots \ldots \ldots \ldots$

9. Summary of peak temperatures measured in FTT with 3 -in.-ID column $\ldots \ldots \ldots \ldots \ldots$

10. Skin temperatures and $\mathrm{UF}_{6}$ flow rate vs time, 1 -in. NaF trap, February $9,1996 \ldots \ldots \ldots$

11. Sodium fluoride temperatures and $\mathrm{UF}_{6}$ flow rate, $\mathrm{SIT} \ldots \ldots \ldots \ldots \ldots \ldots \ldots \ldots$

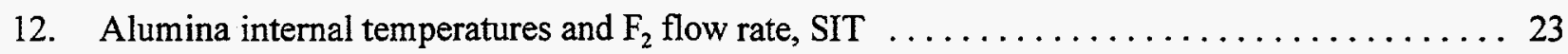

13. Sodium fluoride temperatures and $\mathrm{UF}_{6}$ breakthrough curve, GBTP, March $28,1996 \ldots \ldots 27$

14. Gamma transmission for NDA detectors over entire GBTP $\ldots \ldots \ldots \ldots \ldots \ldots \ldots \ldots$

15. Sodium fluoride temperatures and $\mathrm{UF}_{6}$ flow rate, GBTV-3, April 11, $1996 \ldots \ldots \ldots \ldots$

16. Alumina temperatures and $\mathrm{F}_{2}$ flow rate, GBTV-3, April $11,1996 \ldots \ldots \ldots \ldots \ldots \ldots \ldots$

A-1. TGA of uniform alumina prior to drying $\ldots \ldots \ldots \ldots \ldots \ldots \ldots \ldots \ldots \ldots \ldots \ldots \ldots \ldots \ldots$

A-2. Skin temperatures for FTT-1A, 100-200 sccm fluorine, 1 -in.-ID trap. . . . . . . . . A-4

A-3. Skin temperatures for FTT-1B, 100-200 sccm fluorine, 1 -in.-ID trap $\ldots \ldots \ldots \ldots \ldots \ldots$ A-4

A-4. Skin temperatures for FTT-3A, 300 sccm fluorine $\ldots \ldots \ldots \ldots \ldots \ldots \ldots \ldots \ldots \ldots \ldots$

A-5. Internal temperatures for FTT-3A, $300 \mathrm{sccm}$ fluorine $\ldots \ldots \ldots \ldots \ldots \ldots \ldots \ldots \ldots \ldots$

A-6. Skin temperatures for FTT-3B, $250 \mathrm{sccm}$ fluorine $\ldots \ldots \ldots \ldots \ldots \ldots \ldots \ldots \ldots \ldots \ldots \ldots$ 
A-7. Internal temperatures for FTT-3B, $250 \mathrm{sccm}$ fluorine $\ldots \ldots \ldots \ldots \ldots \ldots \ldots \ldots \ldots$

A-8. Skin temperatures for FTT-3C, $300 \mathrm{sccm}$ fluorine $\ldots \ldots \ldots \ldots \ldots \ldots \ldots \ldots \ldots \ldots$

A-9. Internal temperatures for FTT-3C, $300 \mathrm{sccm}$ fluorine $\ldots \ldots \ldots \ldots \ldots \ldots \ldots \ldots \ldots$

A-10. Skin temperatures for FTT-3D, 500 sccm fluorine $\ldots \ldots \ldots \ldots \ldots \ldots \ldots \ldots \ldots \ldots$

A-11. Internal temperatures for FTT-3D, $500 \mathrm{sccm}$ fluorine $\ldots \ldots \ldots \ldots \ldots \ldots \ldots \ldots \ldots$

A-12. Skin temperatures for FTT $-3 \mathrm{E}, 600 \mathrm{sccm}$ fluorine $\ldots \ldots \ldots \ldots \ldots \ldots \ldots \ldots \ldots$

A-13. Internal temperatures for FTT-3E, $600 \mathrm{sccm}$ fluorine $\ldots \ldots \ldots \ldots \ldots \ldots \ldots \ldots \ldots$

A-14. Skin temperatures for FTT-3F, $600 \mathrm{sccm}$ fluorine $\ldots \ldots \ldots \ldots \ldots \ldots \ldots \ldots \ldots \ldots$

A-15. Internal temperatures for $\mathrm{FTT}-3 \mathrm{~F}, 600$ sccm fluorine $\ldots \ldots \ldots \ldots \ldots \ldots \ldots \ldots \ldots$

A-16. Valve temperatures for FTT-3A, $300 \mathrm{sccm}$ fluorine $\ldots \ldots \ldots \ldots \ldots \ldots \ldots \ldots \ldots \ldots$

A-17. Valve temperatures for $\mathrm{FTT}-3 \mathrm{~B}, 250 \mathrm{sccm}$ fluorine $\ldots \ldots \ldots \ldots \ldots \ldots \ldots \ldots \ldots$

A-18. Valve temperatures for FTT-3C, $300 \mathrm{sccm}$ fluorine $\ldots \ldots \ldots \ldots \ldots \ldots \ldots \ldots \ldots \ldots \ldots$

A-19. Valve temperatures for FTT-3D, $500 \mathrm{sccm}$ fluorine $\ldots \ldots \ldots \ldots \ldots \ldots \ldots \ldots \ldots \ldots \ldots$

A-20. Valve temperatures for $\mathrm{FTT}-3 \mathrm{E}, 600 \mathrm{sccm}$ fluorine $\ldots \ldots \ldots \ldots \ldots \ldots \ldots \ldots \ldots \ldots$

A-21. Valve temperatures for $\mathrm{FTT}-3 \mathrm{~F}, 600 \mathrm{sccm}$ fluorine $\ldots \ldots \ldots \ldots \ldots \ldots \ldots \ldots \ldots \ldots$

A-22. Skin temperatures for FTT-4A, 600 sccm fluorine $\ldots \ldots \ldots \ldots \ldots \ldots \ldots \ldots \ldots \ldots$

A-23. Internal tempertures for FTT-4A, $600 \mathrm{sccm}$ fluorine $\ldots \ldots \ldots \ldots \ldots \ldots \ldots \ldots \ldots$

A-24. Skin temperatures for FTT-4B, $800 \mathrm{sccm}$ fluorine $\ldots \ldots \ldots \ldots \ldots \ldots \ldots \ldots \ldots \ldots$

A-25. Internal temperatures for FTT-4B, $800 \mathrm{sccm}$ fluorine $\ldots \ldots \ldots \ldots \ldots \ldots \ldots \ldots \ldots$

A-26. Valve temperatures for FTT-4A, 600 sccm fluorine $\ldots \ldots \ldots \ldots \ldots \ldots \ldots \ldots \ldots$

A-27. Valve temperatures for FTT-4B, $800 \mathrm{sccm}$ fluorine $\ldots \ldots \ldots \ldots \ldots \ldots \ldots \ldots \ldots$

A-28. Skin temperatures for FTT-5A, $800 \mathrm{sccm}$ fluorine $\ldots \ldots \ldots \ldots \ldots \ldots \ldots \ldots \ldots \ldots \ldots$

A-29. Internal temperatures for FTT-5A, $800 \mathrm{sccm}$ fluorine $\ldots \ldots \ldots \ldots \ldots \ldots \ldots \ldots \ldots$ A-17

A-30. Skin temperatures for FTT-5B, $1000 \mathrm{sccm}$ fluorine $\ldots \ldots \ldots \ldots \ldots \ldots \ldots \ldots \ldots$ 
A-31. Internal temperatures for FTT-5B, $1000 \mathrm{sccm}$ fluorine $\ldots \ldots \ldots \ldots \ldots \ldots \ldots \ldots \ldots$

A-32. Valve temperatures for FTT-5A, $800 \mathrm{sccm}$ fluorine $\ldots \ldots \ldots \ldots \ldots \ldots \ldots \ldots \ldots$

A-33. Valve temperatures for FTT-5A, 1000 sccm fluorine $\ldots \ldots \ldots \ldots \ldots \ldots \ldots \ldots$ A-19

A-34. Peak height $\left(1157 \mathrm{~cm}^{-1}\right)$ vs $\mathrm{UF}_{6}$ partial pressure in the $10-\mathrm{cm}$ IR cell $\ldots \ldots \ldots \ldots \ldots$ A-20

A-35. Peak height $\left(625 \mathrm{~cm}^{-1}\right)$ vs $\mathrm{UF}_{6}$ partial pressure in the $20-\mathrm{cm}$ IR cell $\ldots \ldots \ldots \ldots \ldots \ldots$ A-20

A-36. Sodium fluoride temperatures and $\mathrm{UF}_{6}$ flow rate, GBTP, March $25,1996 \ldots \ldots \ldots \ldots$ A-21

A-37. Alumina temperatures and $\mathrm{F}_{2}$ flow rate, GBTP, March $25,1996 \ldots \ldots \ldots \ldots \ldots$ A-21

A-38. Sodium fluoride temepratures and $U_{6}$ flow rate, GBTP, March $26,1996 \ldots \ldots \ldots$ A-22

A-39. Alumina temperatures and $\mathrm{F}_{2}$ flow rate, GBTP, March $26,1996 \ldots \ldots \ldots \ldots \ldots \ldots$ A-22

A-40. Sodium fluoride temperatures and $\mathrm{UF}_{6}$ flow rate, GBTP, March $27,1996 \ldots \ldots \ldots \ldots$ A-23

A-41. Alumina temperatures and $\mathrm{F}_{2}$ flow rate, GBTP, March $27,1996 \ldots \ldots \ldots \ldots \ldots$ A-23

A-42. Sodium fluoride temperatures and $\mathrm{UF}_{6}$ flow rate, GBTP, March $28,1996 \ldots \ldots \ldots \ldots$ A-24

A-43. Alumina temperatures, no $F_{2}$ flow, GBTP, March $28,1996 \ldots \ldots \ldots \ldots \ldots \ldots$ A-24

A-44. Sodium fluoride temperatures and $\mathrm{UF}_{6}$ flow rate, GBTV-1, April 9, $1996 \ldots \ldots \ldots \ldots$ A-25

A-45. Alumina temperatures and $\mathrm{F}_{2}$ flow rate, GBTV-1, April 9, $1996 \ldots \ldots \ldots \ldots \ldots \ldots$ A-25

A-46. Sodium fluoride temperatures and $\mathrm{UF}_{6}$ flow rate, GBTV-2, April 10, $1996 \ldots \ldots \ldots$. $\ldots$.26

A-47. Alumina temperatures and $\mathrm{F}_{2}$ flow rate, GBTV-2, April $10,1996 \ldots \ldots \ldots \ldots \ldots$ A-26

A-48. Sodium fluoride temperatures and $\mathrm{UF}_{6}$ flow rate, GBTV-4, April $12,1996 \ldots \ldots \ldots \ldots$ A-27

A-49. Alumina temperatures and $\mathrm{F}_{2}$ flow rate, GBTV-4, April 12, $1996 \ldots \ldots \ldots \ldots \ldots$ A 27

A-50. Exit flow measurements, GBTV-2, April 10,1996 ................. A-28

A-51. Tank pressure rise, GBTV-2, April 10, $1996 \ldots \ldots \ldots \ldots \ldots \ldots \ldots \ldots \ldots \ldots \ldots$ A-29

A-52. Gamma transmission received by second NDA detector throughout GBTV ........ A-30 



\section{ACRONYMS}

$\begin{array}{ll}\text { AFMR } & \text { actual flowmeter reading } \\ \text { CPS } & \text { counts per second } \\ \text { FTIR } & \text { Fourier transform interferometer } \\ \text { FTT } & \text { fluorine trapping tests } \\ \text { GBTP } & \text { glove box tests under pressure } \\ \text { GBTV } & \text { glove box tests under vacuum } \\ \text { ID } & \text { internal diameter } \\ \text { IR } & \text { infrared } \\ \text { MSRE } & \text { Molten Salt Reactor Experiment } \\ \text { NDA } & \text { nondestructive analysis } \\ \text { RGRS } & \text { reactive gas removal system } \\ \text { sccm } & \text { standard cubic centimeters per minute } \\ \text { SIT } & \text { simple integrated test } \\ \text { SL } & \text { standard liter (at } 0^{\circ} \mathrm{C} \text { and } 1 \text { atm of pressure) } \\ \text { SLM } & \text { standard liters per minute } \\ \text { TGA } & \text { thermogravimetric analysis } \\ \text { UTT } & \text { UF } 6 \text { trapping tests }\end{array}$





\section{ACKNOWLEDGMENTS}

The laboratory testing of the Molten Salt Reactor Experiment reactive gas removal system was a team effort, and we thank all those involved in the project for their constant support. Special thanks go to Ron Battle and Mike Buchanan of the Instrumentation and Controls Division at Oak Ridge National Laboratory for resolving problems with instrumentation and computer monitoring and to Norm Smyrl and Quirinus Grindstaff of the Analytical Services Organization at the Oak Ridge Y-12 Plant for their assistance with the Fourier transform interferometers. 


\begin{abstract}
The Molten Salt Reactor Experiment (MSRE) at Oak Ridge National Laboratory has been shut down since December 1969, at which time the molten salt mixture of $\mathrm{LiF}-\mathrm{BeF}_{2}-\mathrm{ZrF}_{4}{ }^{233} \mathrm{UF}_{4}$ (64.5-30.3-5.0-0.13 mol \%) was transferred to fuel salt drain tanks for storage. In the late $1980 \mathrm{~s}$, increased radiation in one of the gas lines from the drain tank was attributed to ${ }^{233} \mathrm{UF}_{6}$. In 1994 two gas samples were withdrawn (from a gas line in the Vent House connecting to the drain tanks) and analyzed. Surprisingly, $350 \mathrm{~mm} \mathrm{Hg}$ of $F_{2}, 70 \mathrm{~mm} \mathrm{Hg}$ of $\mathrm{UF}_{6}$, and smaller amounts of other gases were found in both of the samples.

To remove this gas from above the drain tanks and all of the associated piping, the reactive gas removal system (RGRS) was designed. This report details the laboratory testing of the RGRS, using natural uranium, prior to its implementation at the MSRE facility. The testing was performed to ensure that the equipment functioned properly and was sufficient to perform the task while minimizing exposure to personnel. In addition, the laboratory work provided the research and development effort necessary to maximize the performance of the system. Throughout this work, technicians and staff who were to be involved in RGRS operation at the MSRE site worked directly with the research staff in completing the laboratory testing phase. Consequently, at the end of the laboratory work, the personnel who were to be involved in the actual operations had acquired all of the training and experience necessary to continue with the process of reactive gas removal.
\end{abstract}




\section{INTRODUCTION}

The Molten Salt Reactor Experiment (MSRE) was operated at the Oak Ridge National Laboratory from 1965 to 1969 to test the concept of a high-temperature homogeneous fluid-fueled reactor. ${ }^{1}$ It was fueled with a molten salt mixture of $\mathrm{LiF}-\mathrm{BeF}_{2}-\mathrm{ZrF}_{4}-\mathrm{UF}_{4}(64.5-30.3-5.0-0.13 \mathrm{~mol} \%)$, melting at approximately $450^{\circ} \mathrm{C}$, which served as both the fuel and the primary coolant. This fluid was circulated by a large impeller pump between the reactor core and the primary heat exchanger. $A$ secondary coolant of $\mathrm{LiF}_{-} \mathrm{BeF}_{2}(66-34 \mathrm{~mol} \%)$, circulated by a similar impeller pump, transferred or "shuttled" heat from this heat exchanger to an air-cooled radiator. Approximately $4350 \mathrm{~kg}\left(\sim 2 \mathrm{~m}^{3}\right)$ of fuel salt constituted the fuel charge circulating in the fuel salt circuit. Originally, the MSRE was fueled with ${ }^{235} \mathrm{UF}_{4}$; however, after successful operation with this isotope, the ${ }^{235} \mathrm{U}$ was removed by fluorination of the tetrafluoride to the volatile hexafluoride, $\mathrm{UF}_{6}$. Afterward, the salt was reconstituted with ${ }^{233} \mathrm{UF}_{4}$ (containing $220 \mathrm{ppm}^{232} \mathrm{U}$ ) to demonstrate that the system could function equally well on the product of a ${ }^{232} \mathrm{Th}$ thermal breeding cycle. After the successful completion of this campaign, reactor operation was terminated on December 12,1969, when the fuel salt from the reactor circuit was drained and solidified in two drain tanks at a lower level of the MSRE facility.

The fuel salt has remained there for the past 27 years. At the time of the MSRE operation, radiolytic effects on the fuel salt were recognized as a probable occurrence if the salt were stored below $100^{\circ} \mathrm{C}$, with the net effect that fluorine gas $\left(\mathrm{F}_{2}\right)$ could be liberated from the frozen salt mixture and cause corrosion and/or overpressurization of the drain tank containment system. To prevent the accumulation of this halogen gas, the frozen salt (which was normally at approximately $40^{\circ} \mathrm{C}$ due to the self-heating generated by fission product decay) was heated to $250^{\circ} \mathrm{C}$ on an annual basis to recombine the fluorine generated with the "reduced" sites left in the salt. The fluorine pressure in the drain tanks prior to and after annealing was not monitored; therefore, the effectiveness of this annual procedure has never been established.

In the late $1980 \mathrm{~s}$, an increase in radioactivity in one of the gas line protrusions into the North Electrical Services Area, a room adjacent to the drain tank cell, was identified as coming from $\mathrm{UF}_{6}$. Because the annual annealing operation would drive this condensable gas from the drain tanks to cooler surfaces such as the gas line protrusion into the North Electrical Services Area, the annual annealing operation was postponed until a better understanding of the fuel salt behavior was obtained.

In early 1994, two 1000-mL gas samples were withdrawn (from a gas line in the Vent House connecting to the drain tanks) and analyzed. Surprisingly, $350 \mathrm{~mm} \mathrm{Hg}$ of $F_{2}, 70 \mathrm{~mm} \mathrm{Hg}$ of $\mathrm{UF}_{6}$, and smaller amounts of other gases were found in both of the samples (see Table 1), confirming that the 
annual annealing operations had not been successful in recombining the fluorine with the fuel salt and, more importantly, that the temperature gradient created during the annealing operation had definitely contributed to the displacement of $\mathrm{UF}_{6}$ from the fuel salt.

Table 1. Gas analysis of two samples taken from the MSRE off-gas system ${ }^{a}$

\begin{tabular}{lll}
\hline Species & First sample & Second sample \\
\hline $\mathrm{UF}_{6}$ & $70 \mathrm{~mm} \mathrm{Hg}(0.8 \mathrm{~g} / \mathrm{L})$ & $68 \mathrm{~mm} \mathrm{Hg}(0.8 \mathrm{~g} / \mathrm{L})$ \\
$\mathrm{HF}$ & $1200 \mathrm{ppm}$ & $1000 \mathrm{ppm}$ \\
$\mathrm{MoF}_{6}$ & $10 \mathrm{~mm} \mathrm{Hg}$ & $b$ \\
$\mathrm{CF}_{4}$ & $5 \mathrm{~mm} \mathrm{Hg}$ & $b$ \\
$\mathrm{~F}_{2}$ & $c$ & $350 \mathrm{~mm} \mathrm{Hg}$ \\
$\mathrm{He}, \mathrm{Ar}, \mathrm{N}_{2}, \mathrm{O}_{2}{ }^{d}$ & $305 \mathrm{~mm} \mathrm{Hg}$ & $305 \mathrm{~mm} \mathrm{Hg}$ \\
\hline
\end{tabular}

adentification by mass spectroscopy.

${ }^{b}$ Present as in first sample.

Not determined analytically but assumed to be the same as the second sample.

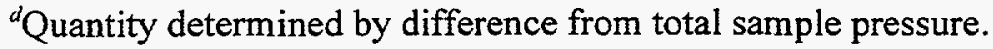

On further investigation, it was found that the gas line from the drain tank also ran to large charcoal beds ( $U$ tubes of 6 -in. diam and 24 - $\mathrm{ft}$ length), which could not be isolated due to a shutoff valve that had failed in the open position. Gamma scan and thermal analyses indicated that $2.6 \mathrm{~kg}$ of the uranium from the drain tanks had been deposited at the charcoal bed inlet. This material, along with carbon-fluorine reaction products, presents chemical as well as radiological hazards. ${ }^{2}$

On November 20,1995, this shutoff valve was closed to prevent the further adsorption of uranium and fluorine onto the charcoal bed. One of the significant remediation activities planned for the MSRE is the removal of the $U_{6}, F_{2}$ and the other gases shown in Table 1. For this purpose, the reactive gas removal system (RGRS) project was initiated. The RGRS was designed to remove the reactive gases from the system using three-stage chemical trapping on solid reagents during evacuation of the off-gas volume. The main components of the system are two chemical traps, one filled with sodium fluoride $(\mathrm{NaF})$ and the other filled with activated alumina $\left(\mathrm{Al}_{2} \mathrm{O}_{3}\right)$. The $\mathrm{UF}_{6}$ present in the MSRE off-gas system will be chemisorbed onto the $\mathrm{NaF}$, forming $\mathrm{Na}_{2} \mathrm{UF}_{8}$, while the fluorine will react with alumina to form aluminum fluoride and oxygen. A third trap containing molecular sieve was added to the system to remove water vapor containing traces of hydrogen fluoride (HF) exiting the alumina trap during fluorine loading. A more detailed description of the RGRS can be found in Technical Bases of Selection of 
Trapping Technology for the MSRE Interim Vent Project. ${ }^{3}$ This report discusses the laboratory test program that was performed to examine the system's capabilities and limitations and to identify any improvements that could be implemented.

\section{OBJECTIVES}

Because of the highly radioactive nature of the ${ }^{233} \mathrm{U}^{232} \mathrm{U}$ daughters and the extreme reactivity and corrosivity of the gases involved, it was necessary to ascertain the compatibility of all of the material and equipment used while minimizing personnel exposure. There were two major objectives of the RGRS testing. The first was to ensure that all process equipment functioned properly and was debugged as much as possible. The process equipment included the actual MSRE reactive gas traps, filled with NaF, alumina, and molecular sieve from the same stock to be used in the process itself. The piping, valves, instrumentation [including pressure transducers, flow controllers, Fourier transform interferometer (FTIR) cells, and thermocouple assemblies], and data monitoring equipment were also to be checked. Based on the results of these tests, recommendations were to be made on modifications and additions that would benefit the overall process. The second objective of the testing was to determine the optimum and safe operating conditions for the overall process. This included maximum gas flow rates, $\mathrm{UF}_{6}$ concentration, maximum trap temperatures, and loading percentage of gas traps. The laboratory testing operations have been developed through several stages, which are detailed in this report: (1) fluorine trapping tests (FTT); (2) uranium trapping tests (UTT); (3) simple integrated tests (SIT), which combine the previous two traps in the testing procedure; (4) glove box tests at positive pressure (GBTP); and (5) glove box test under vacuum conditions (GBTV). The test runs are identified with these designations so that the reader can more easily follow the numerous figures and other results.

\section{DESCRIPTION OF TEST APPARATUS}

Figure 1 is a schematic representation of the system used to perform the fluorine trapping tests. The standard equipment used for the fluorine tests is listed in Table 2. To make rapid progress, the initial test setup was small and very simple, achieving full scale only near the end of testing. The use of a simple flanged 1-in.-ID pipe alumina bed was particularly useful in the early tests because complete trials could be completed in only a day or two, and the results provided guidance about limits on the operating parameters (e.g., maximum permissible fluorine flow). 
As depicted in Fig. 1, five thermocouples (TE 1-5) recorded outer-wall (i.e., "skin")

temperatures, while the other five thermocouples (TE 6-10) registered the internal temperatures and were located in an axial thermowell located about halfway between the centerline and the wall (i.e., the "core" temperature).

Table 2. Equipment used in fluorine trapping tests (FTT)

\begin{tabular}{ll}
\hline Equipment item & Description \\
\hline Alumina trap (1 in.) & 1 in.- ID $\times 12$-in. - long nickel-plated flanged pipe \\
Alumina trap (3 in.) & MSRE trap, drawing ${ }^{a}$ \\
He flowmeter/controller & FC-260, Tylan Corp. \\
F $_{2}$ flowmeter/controller & FC-260, Tylan Corp. \\
Data logging and control & SCXI-1000 - Labview - National Instruments Interface \\
Thermocouples & Type K, 1/8 in. and 1/16 in. \\
Pressure transducers & Baratron Model 146, MKS, Inc. \\
\hline “MSRE HF/F ${ }_{2}$ Trap Assembly," LMES Central Engineering Services Drawing No. X3E020794A013.
\end{tabular}

Thermocouples 11 and 12 logged temperatures from the lines leading to the inlet and outlet valve to the alumina bed, respectively. Pressures at the trap inlet and outlet were also measured during the 3-in.-column runs, but a significant pressure drop was never detected.

Figure 2 is a schematic representation of the $\mathrm{UF}_{6}$ trapping test. The $\mathrm{NaF}$ trap was the same 1-in.-diam trap used in the initial fluorine tests. $A_{\text {U }} \mathrm{UF}_{6}$ saturator, consisting of a nickel vessel with a dip tube, was used to add $\mathrm{UF}_{6}$ to the gas stream. The saturator was kept at the desired temperature with a water bath. This temperature was used to control the $\mathrm{UF}_{6}$ concentration at a given helium flow rate. Thermocouples TE 1-5 measured the skin temperatures at five axial locations along the NaF trap. Also shown is a $10-\mathrm{cm}$-long gas cell with zinc selenide ( $\mathrm{ZnSe}$ ) windows connected to an infrared (IR) spectrometer (FTIR Bomem MB-104) that was used to continuously determine UF $_{6}$ inlet concentration, except when nearing breakthrough, at which time where it was used to continuously monitor to obtain the breakthrough curve.

Figure 3 shows a schematic of the simple test that integrated the trapping of fluorine and $\mathrm{UF}_{6}$ from a pressurized source. The actual MSRE traps were used in this test. TE 1-5 and TE 6-10 measured the internal temperatures of the $\mathrm{NaF}$ and alumina traps, respectively. TE 11-15 measured "skin" temperatures of the alumina trap, while TE 16-17 monitored the temperatures of the valves connected to the alumina trap. 
Figure 4 shows a diagram of the process equipment used to generate and control the flow of gases into the glove box containing the traps. Inlet and outlet flowmeters (Tylan Corporation, FC$2901 \mathrm{~V}$ ) were added to the system to measure overall flow rates. Also an actual MSRE trap filled with molecular sieve was added downstream of the alumina trap to retain water and residual hydrofluoric acid released because of the high temperatures in the alumina trap. Refer to the MSRE drawing ${ }^{4}$ for glove box details.

Figure 5 illustrates the system that simulated the proposed removal of gases from the MSRE offgas system by evacuation.

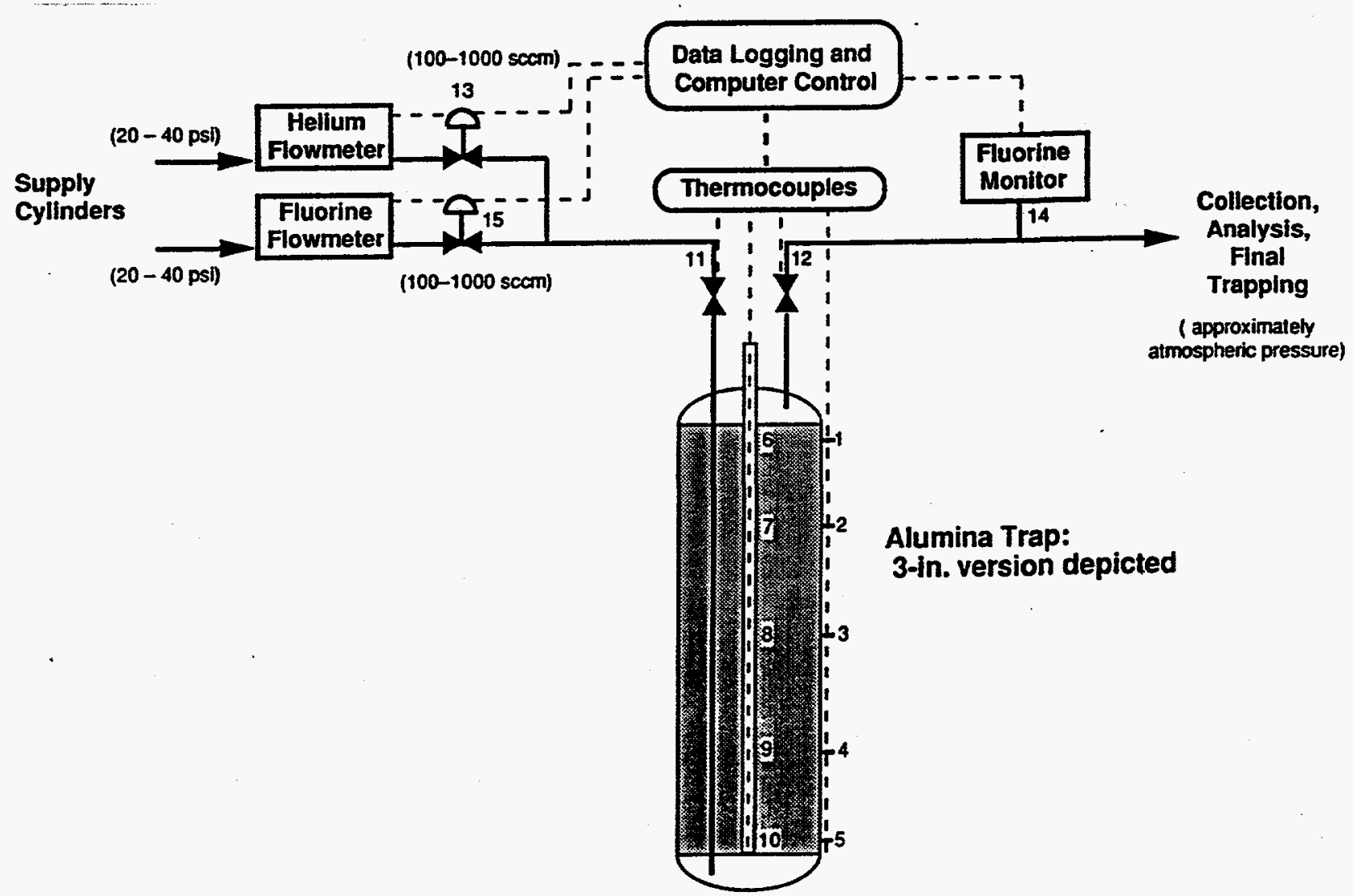

Fig. 1. Diagram of fluorine trapping test (FTT). 


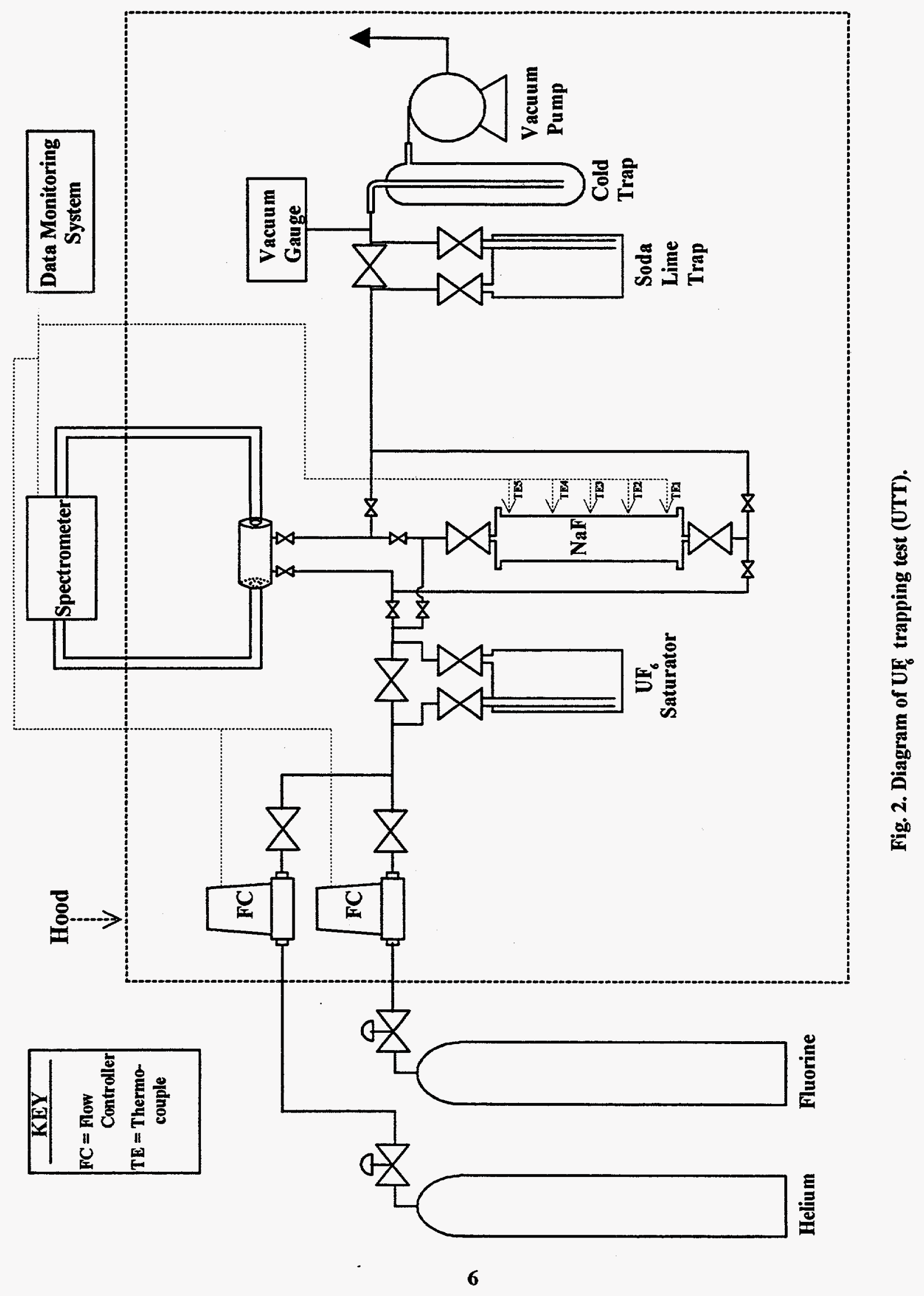




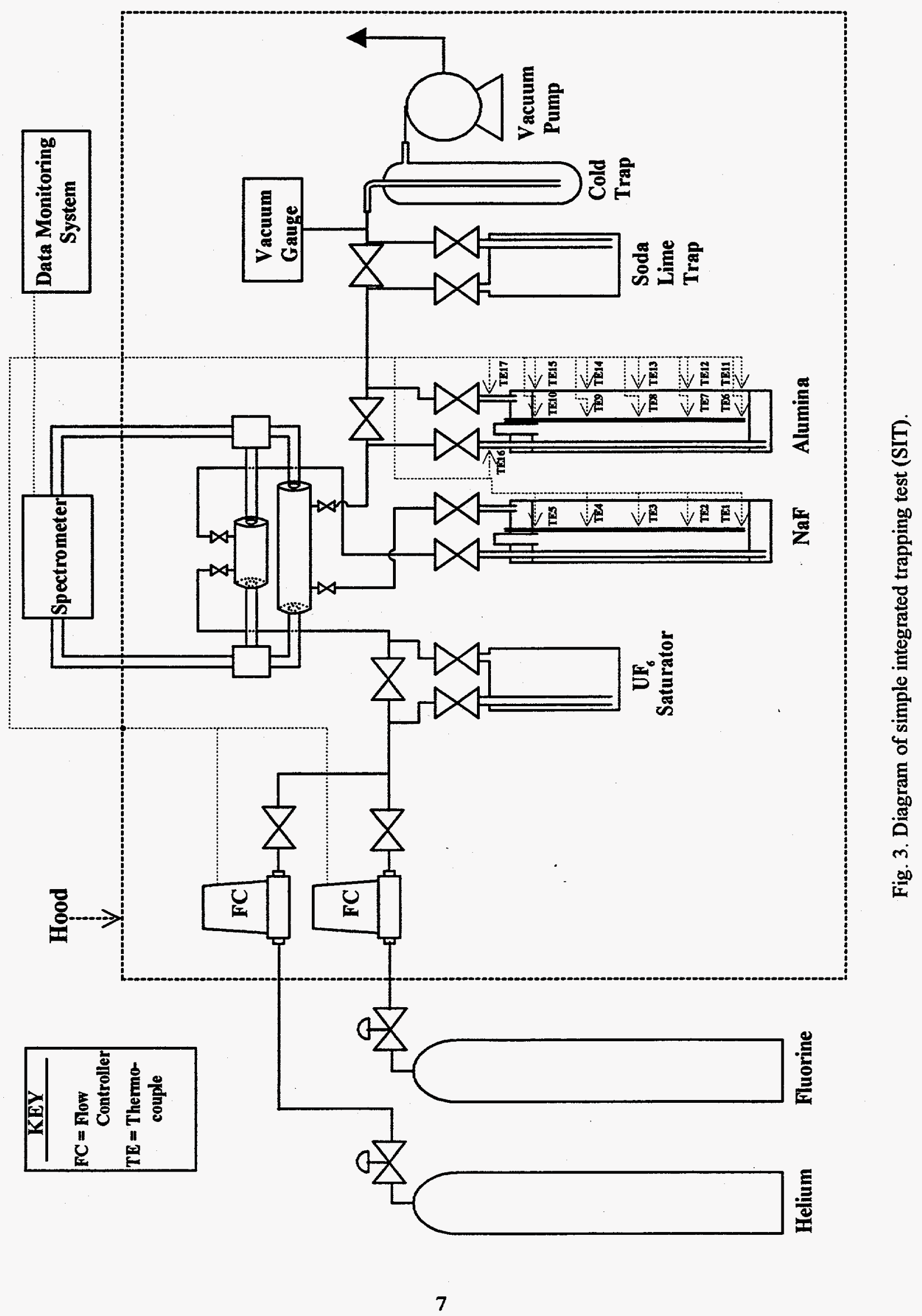




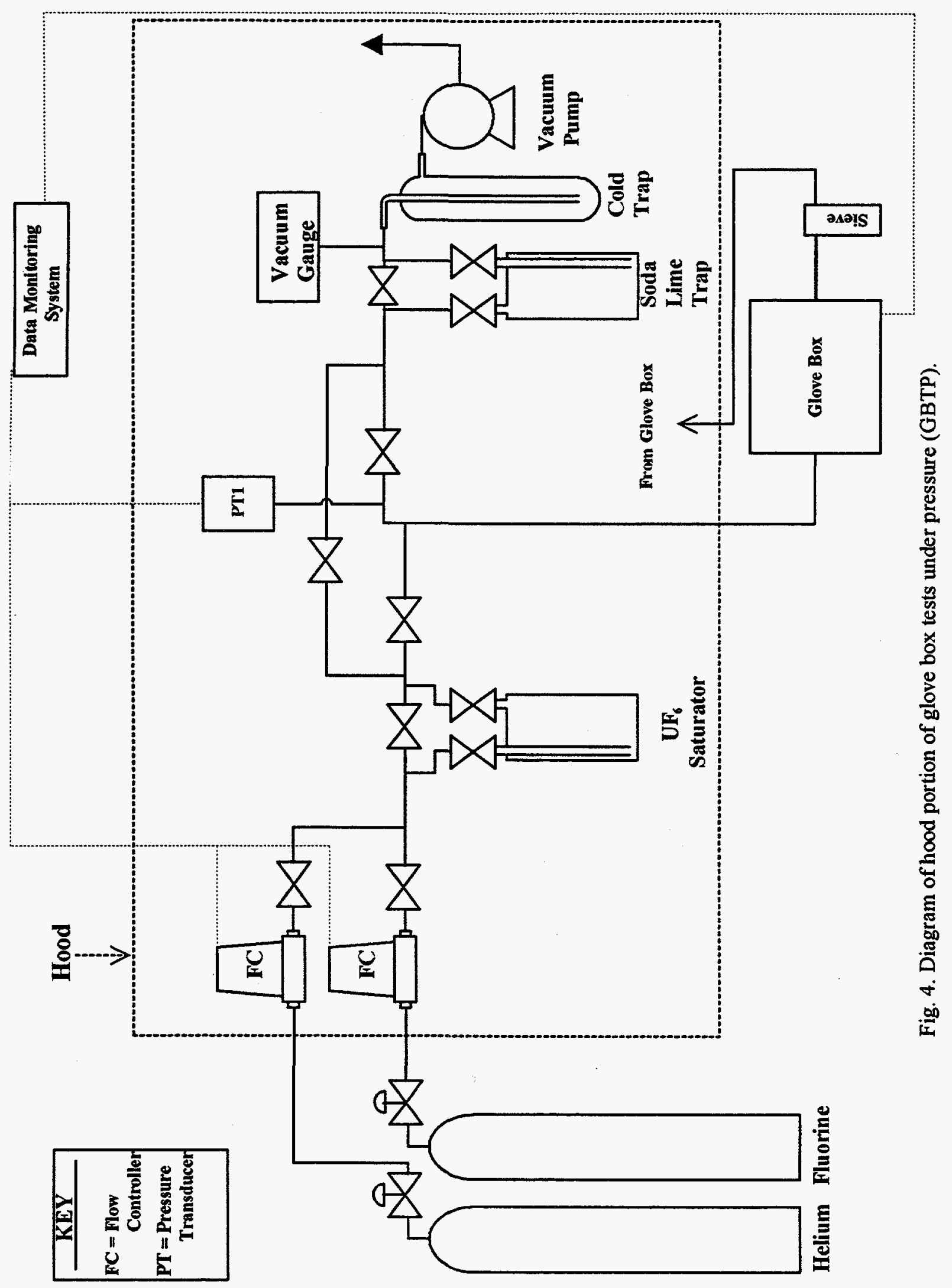




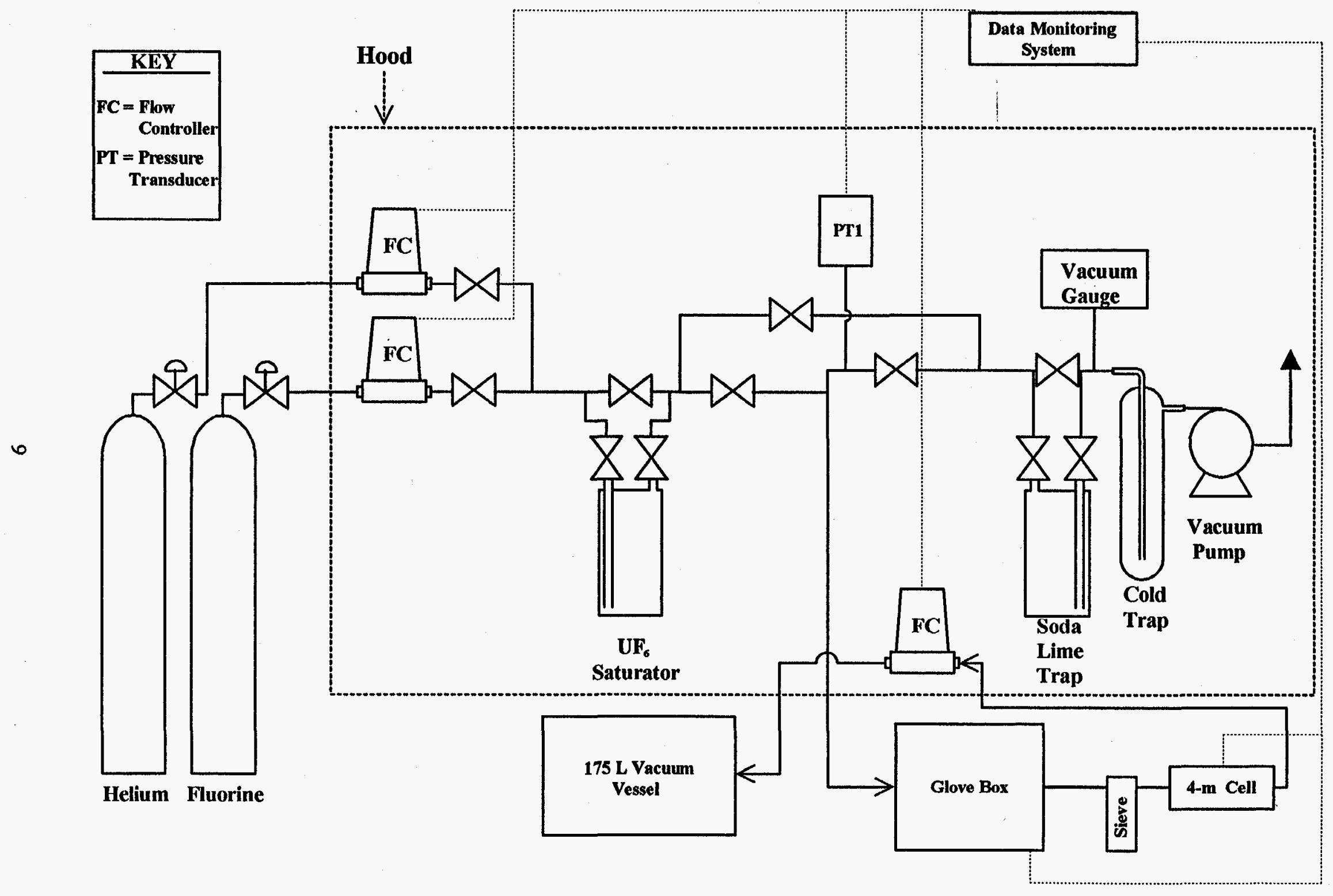

Fig. 5. Diagram of hood portion of glove box tests under vacuum (GBTV). 


\section{DESCRIPTION AND PROPERTIES OF GAS TRAPPING MATERIAL}

Three different gas trapping materials were implemented in the RGRS process: NaF (to trap $\mathrm{UF}_{6}$ ); alumina (to trap fluorine); and a molecular sieve, which is a high-surface-area sodium aluminosilicate (to trap water and HF being produced in the alumina trap). As mentioned in the introduction, the molecular sieve was introduced into the process after it was observed that aqueous HF was emitted at the outlet of the alumina trap. The properties of all the materials tested are given in Tables 3-5.

Table 3. Physical properties of NaF pellets for MSRE

\begin{tabular}{llll}
\hline Physical property & Units & Portsmouth $\mathrm{NaF}^{a}$ & $\mathrm{~K}-25 \mathrm{NaF}(1987)^{b}$ \\
\hline Pellet diameter & $\mathrm{cm}$ & 0.42 & 0.31 \\
BET surface area & $\mathrm{m}^{2} / \mathrm{gm}$ & 0.1 & 1.4 \\
Helium density (dry) & $\mathrm{gm} / \mathrm{cm}^{3}$ & 2.77 & 2.79 \\
Pellet density (dry) & $\mathrm{gm} / \mathrm{cm}^{3}$ & 1.96 & 1.49 \\
Bulk density (dry) & $\mathrm{gm} / \mathrm{cm}^{3}$ & 1.02 & 0.85 \\
Water loss on mild & $\mathrm{wt} \%$ & $0.2 \%$ & $-\cdots$ \\
drying & & & \\
\hline
\end{tabular}

Measurements made by L. E. Powell, Membrane Technology Department, Oak Ridge K-25 Site, Jan. 17, 1996.

${ }^{b} \mathrm{~K}-25 \mathrm{NaF}$ tests: R. G. Russell, KY/L-1457 (1987).

Table 4. Summary of alumina properties ${ }^{a}$

\begin{tabular}{|c|c|c|}
\hline Physical property & Granular alumina $^{b}$ & Uniform alumina $^{\circ}$ \\
\hline BET surface area $\left(\mathrm{m}^{2 /} \mathrm{g}\right)$ & 208 & 346 \\
\hline He density, dry ${ }^{d i}\left(\mathrm{~g} / \mathrm{cm}^{3}\right)$ & 3.19 & 3.31 \\
\hline Pellet density, dry $\left(\mathrm{g} / \mathrm{cm}^{3}\right)$ & - & 1.21 \\
\hline Bulk density, dry $\left(\mathrm{g} / \mathrm{cm}^{3}\right)$ & 0.81 & 0.67 \\
\hline Weight loss on mild drying (\%) & 15.5 & 1.2 \\
\hline
\end{tabular}


Table 5. Summary of molecular sieve $(13 \mathrm{X})$ properties $^{a}$

\begin{tabular}{ll}
\hline Physical property & \\
\hline Diameter $(\mathrm{cm})$ & 0.318 \\
Bulk density $\left(\mathrm{g} / \mathrm{cm}^{3}\right)$ & 0.61 \\
Equilibrium $\mathrm{H}_{2} \mathrm{O}$ capacity $(\mathrm{wt} \%)$ & 28.5 \\
Heat of adsorption $\left(\mathrm{kcal} / \mathrm{g} \mathrm{H}_{2} \mathrm{O}\right)$ & 1.00 \\
\hline
\end{tabular}

${ }^{a}$ Handbook of Separation Techniques for Chemical Engineers, ed. P. A. Schweitzer, McGraw Hill Book Company, pp. 3-22, New York, 1979.

The $\mathrm{NaF}$ used in the test runs was received as sodium bifluoride $\left(\mathrm{NaHF}_{2}\right)$. The material was heated to $400^{\circ} \mathrm{C}$ for periods in excess of $24 \mathrm{~h}$ with a helium purge to remove HF. The material was then fluorinated at $0.3 \mathrm{~atm}$ for $30 \mathrm{~min}$ (also at $400^{\circ} \mathrm{C}$ ) to remove any residual oxides from the system.

The alumina was also pretreated by heating for periods greater than $3 \mathrm{~h}$ under a helium purge to reduce the water content. For the initial test, the alumina was dried at $300^{\circ} \mathrm{C}$. For the remaining FTT, it was treated at $400^{\circ} \mathrm{C}$; for the integrated tests, it was treated at $600^{\circ} \mathrm{C}$ (Table 6). The reason for the increased treatment temperature was to minimize the moisture (and therefore the HF) liberated during fluorine loading.

Table 6. Preparative drying results for alumina ${ }^{a}$

\begin{tabular}{cccc}
\hline Material & Drying temperature $\left({ }^{\circ} \mathrm{C}\right)$ & Drying period $(\mathrm{h})$ & $\%$ Weight loss \\
\hline Granular alumina & 30 & 2 & 12 \\
& & 4 & 20.9 \\
Uniform alumina & & 7 & 21.6 \\
& 300 & 24 & 21.6 \\
& 400 & $4-6$ & $3.4-4.1$ \\
& 500 & $4-6$ & $4.5-5.1$ \\
& 600 & $3-6$ & $5.5-6.5$ \\
& & $3-4$ & $6.0-7.0$ \\
\hline
\end{tabular}

${ }^{a}$ All drying conducted with a helium purge. 
Thermogravimetric results on a small sample of uniform alumina are shown in Fig. A.1 (see Appendix A). The molecular sieve material (a porous sodium aluminosilicate cage) was treated by heating at $200^{\circ} \mathrm{C}$ for $24 \mathrm{~h}$ with a helium purge.

\section{FLUORINE TRAPPING RESULTS (FTT)}

The major test parameters were (1) trap diameter, (2) fluorine flow rate, and (3) the wall condition, that is, "naked" or "shrouded" operation (with or without carrier in place). The values of these primary parameters for the fluorine trapping trials are summarized in Table 7.

Table 7. Major parameters for fluorine trapping tests (FTT)

\begin{tabular}{cccccc}
\hline FTT no. & Trial date & $\begin{array}{c}\text { Column ID } \\
\text { (in.) }\end{array}$ & $\begin{array}{c}\text { Nominal fluorine } \\
\text { flow (SLM) }\end{array}$ & $\begin{array}{c}\text { Wall } \\
\text { condition }\end{array}$ & $\begin{array}{c}\text { Type of } \\
\text { alumina }\end{array}$ \\
\hline 1A & $11 / 15 / 95$ & 1 & $0.10-0.20$ & Naked & Granular \\
1B & $11 / 16 / 95$ & 1 & $0.10-0.20$ & Naked & Granular \\
2 & $11 / 22 / 95$ & 1 & 0.15 & Naked & Uniform \\
3A & $11 / 29 / 95$ & 3 & 0.30 & Naked & Uniform \\
3B & $11 / 30 / 95$ & 3 & 0.25 & Naked & Uniform \\
3C & $12 / 1 / 95$ & 3 & 0.30 & Naked & Uniform \\
3D & $12 / 4 / 95$ & 3 & 0.50 & Naked & Uniform \\
3E & $12 / 5 / 95$ & 3 & 0.60 & Naked & Uniform \\
3F & $12 / 6 / 95$ & 3 & 0.60 & Naked & Uniform \\
4A & $12 / 18 / 95$ & 3 & 0.60 & Shrouded & Uniform \\
4B & $12 / 21 / 95$ & 3 & 0.80 & Shrouded & Uniform \\
5A & $1 / 8 / 96$ & 3 & 0.80 & Shrouded & Uniform \\
5B & $1 / 9 / 96$ & 3 & 1.00 & Shrouded & Uniform \\
\hline
\end{tabular}

The term "nominal" fluorine flow represents an average flow after it stabilized. The flow was started at a low value at the beginning of a run and increased in steps to avoid uncontrolled excursions. This had only a minor effect upon the peak temperatures and the breakthrough behavior. In all cases the helium flow was roughly equal to the fluorine flow. 
The first two runs, made using a 1-in.-ID column, present the clearest picture of an uninterrupted trap loading. For these runs ( $1 \mathrm{~A}$ and $\mathrm{B}, 2$ ), only the skin temperature was measured. During the first trial the fluorine flow was changed a number of times in the 0.10-0.20 standard liter per minute (SLM) range, in order to find the maximum flow consistent with a $300^{\circ} \mathrm{C}$ skin temperature (Figs. A.2 and A.3, see Appendix A). It appears that this flow is somewhere between 0.15 and 0.20 SLM of fluorine for a 1-in-ID trap with granular alumina. The second test involved a complete loading trial (Fig. 6) and was conducted using the actual uniform spherical alumina particles to be used at MSRE. The fluorine flow was held steady at 0.15 SLM during the entire run, and a distinct fluorine breakthrough was evident at the end of the run. Fluorine breakthrough occurred just after the temperature maximum at the bed exit was reached (Fig. 7). It was obvious from these runs that the initial design flow rate of $20 \mathrm{~L} / \mathrm{min}$ was too high by at least one, and possibly two, orders of magnitude.

The first series of trials with the 3-in.-ID trap (test no. 3) was conducted "naked" (i.e., without the trap carrier in place.) It required 6 days of flow to completely load the trap at fluorine flow rates that ranged from 0.30 to $0.60 \mathrm{SLM}$. During each successive trial the nominal fluorine flow was increased to determine its influence on the measured bed temperatures. The results from these trials are somewhat marred due to a data-logging error caused by a bug in the software that produces steps in the measured temperatures (Figs. A.4 to A.15 in Appendix A). However, it was confirmed that the logged temperatures were substantially correct during the trial by comparison with an independent readout device. Again the fluorine breakthrough occurred near the maximum in temperature at the bed exit (Fig. 8). For these runs the valve temperatures ranged from 20 to $105^{\circ} \mathrm{C}$, as seen in Figs. A.16 to A.21 (Appendix A).

The second set of trials with the 3-in. bed (test no. 4) was conducted with the trap loaded in its carrier (i.e., "shrouded") and at the highest fluorine flow rates that were expected to be tolerable $\left(0.60-0.80\right.$ SLM). The bed and valve temperatures for these runs ranged from 20 to $180^{\circ} \mathrm{C}$ and are shown in Figs. A.22-A.27 (Appendix A).

The final operation with the 3-in.-ID trap was conducted at a fluorine flow rate of $0.80-1.00$ SLM with the carrier in place. The main purpose was to identify the maximum temperature the trap could reach under these flow conditions. It was not necessary to run to breakthrough to achieve this objective. The bed and valve temperatures for this test are displayed in Figs. A.28-A.33 in Appendix A.

A fairly consistent trend can be seen when the maximum observed temperatures are plotted as a function of the fluorine flow rate. Figure 9 and Table 8 suggest that the peak temperatures (skin, 
internal, and valve) are proportional to the fluorine flow rate. Measured internal temperatures were $100-200^{\circ} \mathrm{C}$ hotter than the skin temperatures. The actual temperature in the alumina particles is significantly hotter than the measured internal temperatures. The presence of the external carrier around the trap accounts for about a $100^{\circ} \mathrm{C}$ rise in both the skin and internal temperatures at the $0.60-\mathrm{SLM}$ fluorine flow rate.

Table 9 contains the overall trap loadings achieved after operation up to breakthrough. The

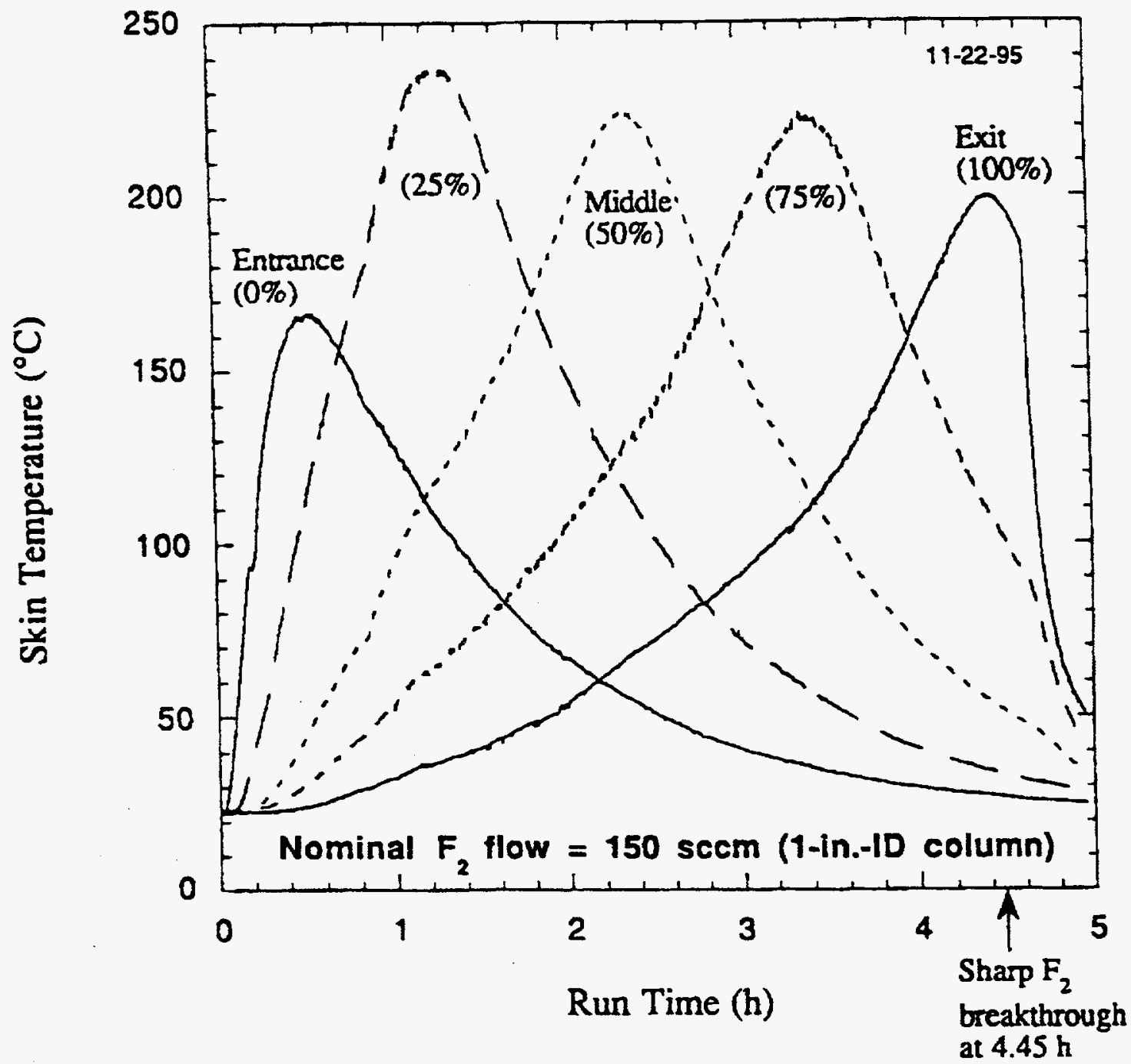

Fig. 6. Skin temperatures for FTT-2, $150 \mathrm{sccm}$ fluorine, 1-in.-D trap. 


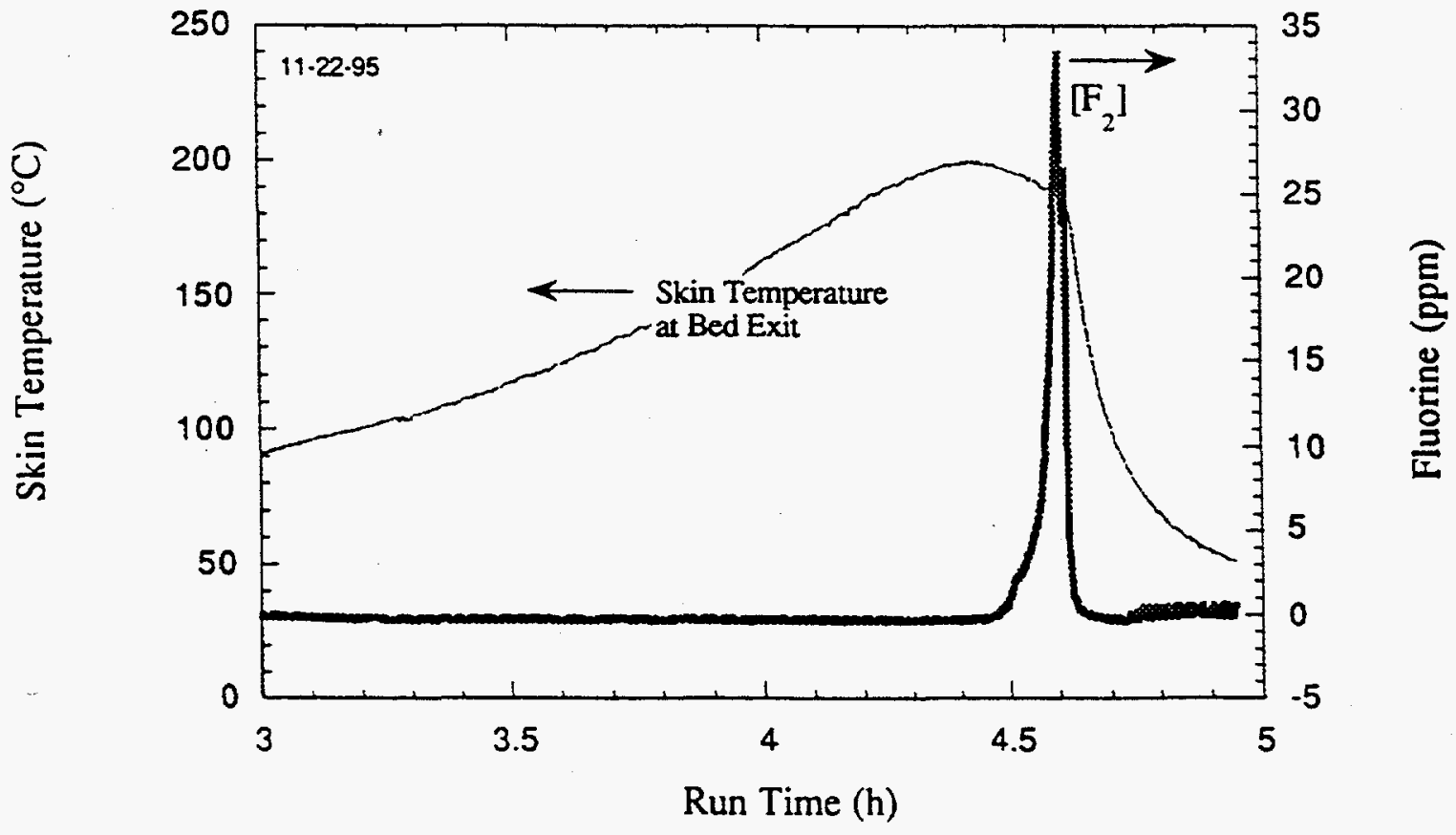

Fig. 7. Fluorine breakthrough during FTT-2, $150 \mathrm{sccm}$ fluorine, 1 -in.-ID trap.

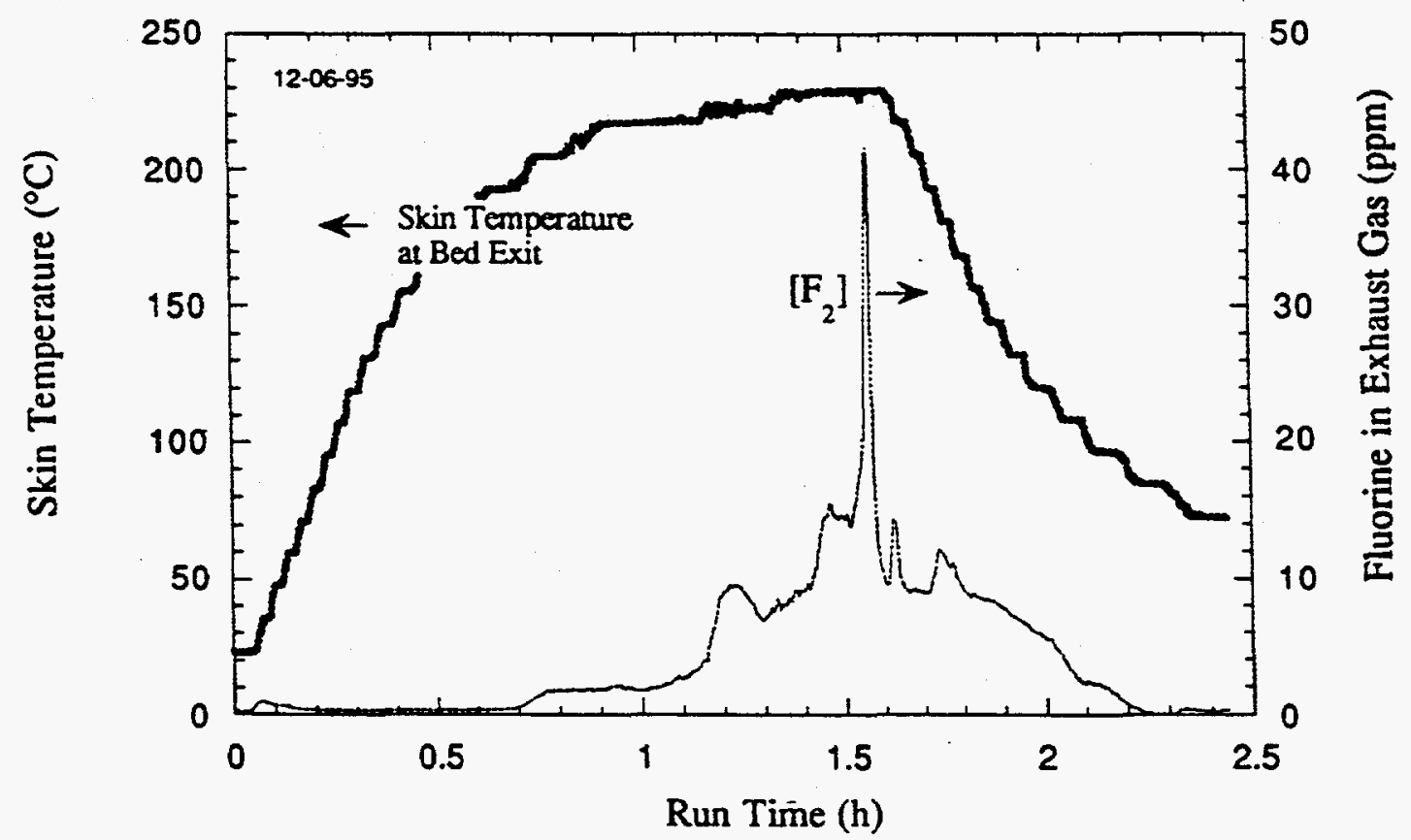

Fig. 8. Fluorine breakthrough during FTT-3F, $600 \mathrm{sccm}$ fluorine, 3-in.-D trap. 
Table 8. Peak temperatures measured in 3-in. alumina bed

\begin{tabular}{ccccc}
\hline $\begin{array}{c}\text { Fluorine flow } \\
(\mathrm{SLM})\end{array}$ & $\begin{array}{c}\text { Wall } \\
\text { condition }\end{array}$ & $\begin{array}{c}\text { Skin temperature } \\
\left({ }^{\circ} \mathrm{C}\right)\end{array}$ & $\begin{array}{c}\text { Interior } \\
\text { temperature }\left({ }^{\circ} \mathrm{C}\right)\end{array}$ & $\begin{array}{c}\text { Outlet valve } \\
\text { temperature }\left({ }^{\circ} \mathrm{C}\right)\end{array}$ \\
\hline 0.30 & "Naked" & 149 & 270 & 28 \\
0.50 & & 216 & 382 & 48 \\
0.60 & & 254 & 452 & 104 \\
0.60 & "Shrouded" & 375 & 540 & 60 \\
0.80 & & 450 & 640 & 180 \\
1.00 & & 460 & 695 & - \\
\hline
\end{tabular}

Table 9. Measured fluorine loading of alumina traps

\begin{tabular}{|c|c|c|c|c|c|}
\hline \multirow[b]{2}{*}{ FTT no. } & \multicolumn{2}{|c|}{ Measured peak temperature $\left({ }^{\circ} \mathrm{C}\right)$} & \multirow[b]{2}{*}{$\begin{array}{c}\% \text { Weight } \\
\text { gain }\end{array}$} & \multirow{2}{*}{$\begin{array}{l}\text { Loading } \\
\text { (liters } \mathrm{F}_{2} \text { per } \\
\text { gram alumina) }\end{array}$} & \multirow{2}{*}{$\begin{array}{c}\text { Theoretical } \\
\text { loading } \\
(\%)\end{array}$} \\
\hline & Skin & Interior & & & \\
\hline 1 & 330 & - & 41 & 0.415 & 63.4 \\
\hline 2 & 240 & - & 36 & 0.366 & 55.6 \\
\hline 3 & 250 & 420 & 44.9 & 0.457 & 69.3 \\
\hline 4 & 450 & 580 & 45 & 0.458 & 69.5 \\
\hline
\end{tabular}

loadings correlate as expected with the temperature of the bed. The weight change per standard liter (SL) of fluorine, based on a stoichiometric reaction with alumina, is 1.014 SL per gram of weight change (see Appendix B). This provides a quick estimate of the fluorine trapped.

Some final comments are required regarding the fluorine breakthrough during the hightemperature operation of the 3 -in. traps during tests 4 and 5 . For these runs the fluorine breakthrough was somewhat obscured by the presence of $\mathrm{HF}$ in a moist atmosphere. The $\mathrm{F}_{2}$ breakthrough in Fig. 8 is correct, but small amounts of HF left the trap long before the true breakthrough. The water vapor resulted from the dehydration of alumina due to the extreme heating in the reaction front beyond the temperatures originally used to dry the alumina (in this case, $\sim 400^{\circ} \mathrm{C}$ ). This moist, corrosive, and acidic exhaust collected as a liquid in the cool exit lines and in a downstream cold trap. Thus a clear 


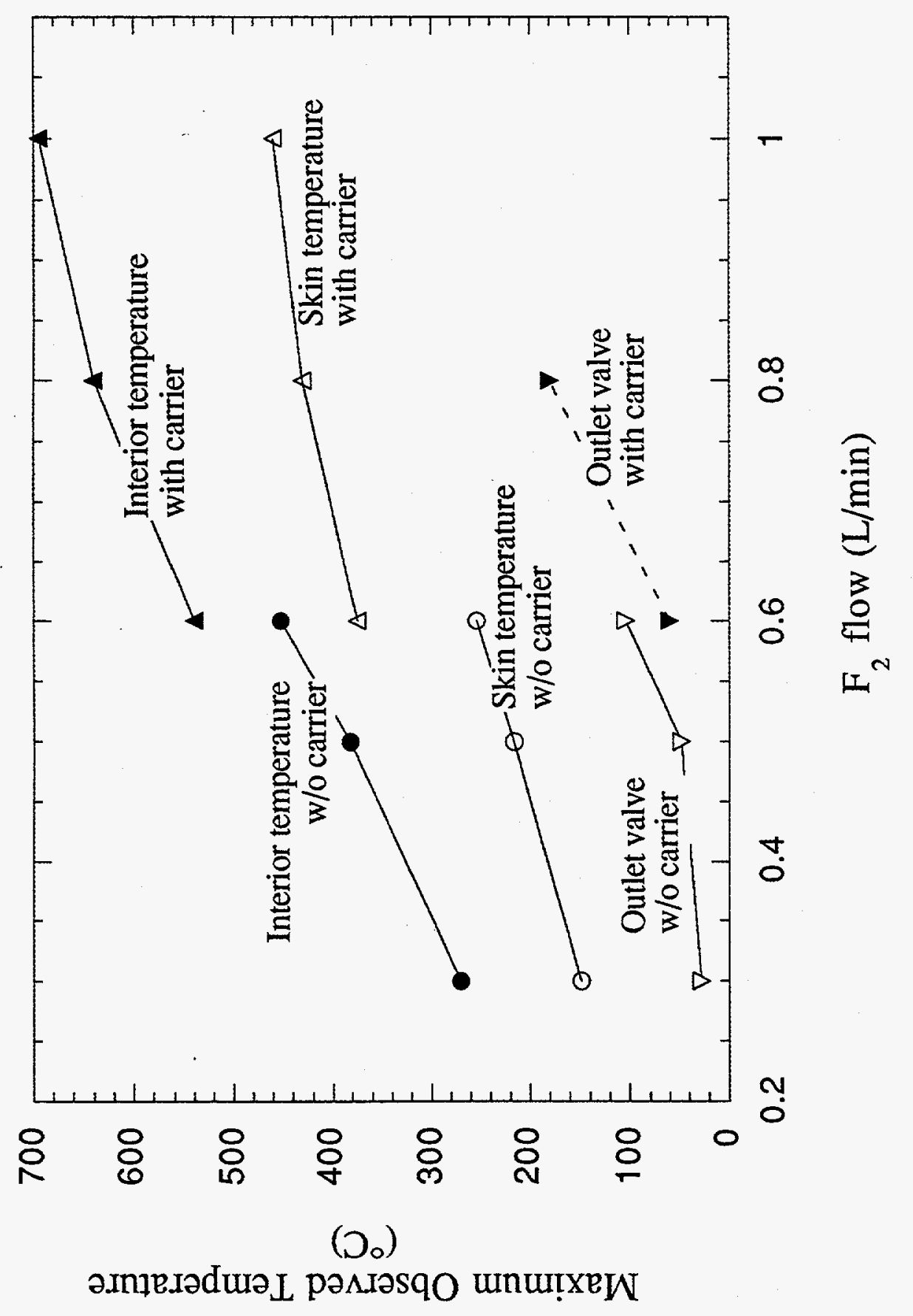

远 
(measured) history of the evolution of HF from the trap exhaust is not available. A summary of the fluid collected during runs 4 and 5 is presented in Table 10.

Table 10. Characteristics of liquid collected from the alumina trap exhaust

\begin{tabular}{ccc}
\hline FTT no. & Volume $(\mathrm{mL})$ & {$\left[\mathrm{F}^{-}\right](M)$} \\
\hline 4 & 8.4 & 0.36 \\
5 & 16.5 & 0.03 \\
\hline
\end{tabular}

The liquid collected from run 4 is only a portion of the condensable vapor that was generated near the completion of the run, but the liquid from run 5 represents all of the vapor in the exhaust gas. Note that the fluid is mainly water, and that for run 5 , when only $50 \%$ of the trap was reacted, the fluo. xue concentration was much lower. The metal ions present, shown in Table 11 for run 4, originated from corrosion of the metal parts present in the exhaust piping. An examination of the bronze elements of the exit valve revealed severe corrosion, which correlated with the difficulty of maintaining a good valve seal during and after operation.

\section{UF 6 TRAPPING RESULTS (UTT)}

The $\mathrm{UF}_{6}$ trapping test was a simple test that had several purposes. The most important was to examine the loading characteristics of $\mathrm{UF}_{6}$ onto the $\mathrm{NaF}$. It was necessary to make sure that the $\mathrm{NaF}$ pellets could effectively trap $U_{6}$ at the same flow rates used in the $F_{2}$ trapping tests. The $U F_{6}$ inlet and outlet concentrations were determined by FTIR spectroscopy. The spectrometer was calibrated with known partial pressures of $\mathrm{UF}_{6}$ to obtain a calibration curve (Fig. A.34, see Appendix A). This calibration curve agrees very well with literature data. ${ }^{5}$ Another calibration with low concentrations of $\mathrm{UF}_{6}$ (as would be expected at breakthrough) was also performed (Fig. A.35). The IR absorbances for these gases were only $\sim 50 \%$ of those predicted by the literature. ${ }^{5}$ It is believed this was because the system was not completely passivated and some of the $\mathrm{UF}_{6}$ deposited on the walls. The lower absorbances were apparent in the second calibration, and not in the first, because of the very low pressures used in the second. However, the calibration is conservative since, for given absorbance, the partial pressure translated is higher than that given in the literature. ${ }^{5}$ Therefore, the total amount of material which breaks through is overestimated. The test was also used to evaluate the behavior of the $\mathrm{UF}_{6}$ saturator as a means of transferring $\mathrm{UF}_{6}$ to the gas stream and the FTIR as an on-line analysis 
technique. The test conditions are shown in Table 12. The results showed that the $\mathrm{UF}_{6}$ saturator worked well, but the water bath temperature had to be continuously adjusted to obtain a relatively constant inlet concentration of $\mathrm{UF}_{6}$ (Fig. 10). The maximum temperature observed on the $\mathrm{NaF}$ trap was $54^{\circ} \mathrm{C}$ (Fig. 10).

Table 11. Metals analysis of FTT- 4 condensate ${ }^{a}$

\begin{tabular}{|c|c|}
\hline Metal & $\begin{array}{l}\text { Result } \\
(\mathrm{mg} / \mathrm{L})\end{array}$ \\
\hline $\mathrm{Ag}$ & $<0.25$ \\
\hline $\mathrm{Al}$ & 10.0 \\
\hline As & $<2.5$ \\
\hline B & $<4.0$ \\
\hline $\mathrm{Ba}$ & $<0.05$ \\
\hline $\mathrm{Be}$ & $<0.05$ \\
\hline $\mathrm{Ca}$ & 0.74 \\
\hline $\mathrm{Cd}$ & $<0.25$ \\
\hline Co & 7.1 \\
\hline $\mathrm{Cr}$ & 330.0 \\
\hline $\mathrm{Cu}$ & 4.5 \\
\hline $\mathrm{Fe}$ & 1000.0 \\
\hline $\mathrm{Li}$ & 98.0 \\
\hline $\mathrm{Mg}$ & $<1.0$ \\
\hline $\mathrm{Mn}$ & 36.0 \\
\hline Mo & $<2.0$ \\
\hline $\mathrm{Na}$ & 29.0 \\
\hline $\mathrm{Ni}$ & 1200.0 \\
\hline $\mathrm{P}$ & $<15.0$ \\
\hline $\mathrm{Pb}$ & $<2.5$ \\
\hline $\mathrm{Sb}$ & $<2.5$ \\
\hline $\mathrm{Se}$ & $<5.0$ \\
\hline $\mathrm{Si}$ & 46.0 \\
\hline $\mathrm{Sn}$ & $<2.5$ \\
\hline $\mathrm{Sr}$ & $<0.05$ \\
\hline $\mathrm{Ti}$ & $<2.0$ \\
\hline V & $<0.1$ \\
\hline $\mathrm{Zn}$ & 2.7 \\
\hline $\mathrm{Zr}$ & $<2$ \\
\hline
\end{tabular}

${ }^{a}$ Analysis Procedure No. EPA 200.7. 
Table 12. Test conditions for $\mathrm{UF}_{6}$ loading onto 1-in. NaF trap

\begin{tabular}{|c|c|}
\hline Amount of $\mathrm{NaF}$ used & $96.1 \mathrm{~g}$ \\
\hline \multirow[t]{3}{*}{ Helium flow rates } & $0.1 \mathrm{SL} / \mathrm{min}$ for $<8 \mathrm{~min}$ \\
\hline & $0.5 \mathrm{SL} / \mathrm{min}$ for $8-22 \mathrm{~min}$ \\
\hline & 1.2 SL/min for $22-63 \mathrm{~min}$ \\
\hline $\mathrm{UF}_{6}$ partial pressure & $45-80$ torr \\
\hline Total pressure & Atmospheric \\
\hline $\mathrm{UF}_{6}$ loaded & $74.8 \mathrm{~g}$ (by weight), $75.1 \mathrm{~g}$ (by flow data) \\
\hline NaF utilization & $0.78 \mathrm{~g} \mathrm{UF}_{6} / \mathrm{g} \mathrm{NaF}(68 \%$ of theoretical) \\
\hline Eruilibrium loading & $1.15 \mathrm{~g} \mathrm{UF}_{6} / \mathrm{g} \mathrm{NaF}$ \\
\hline
\end{tabular}

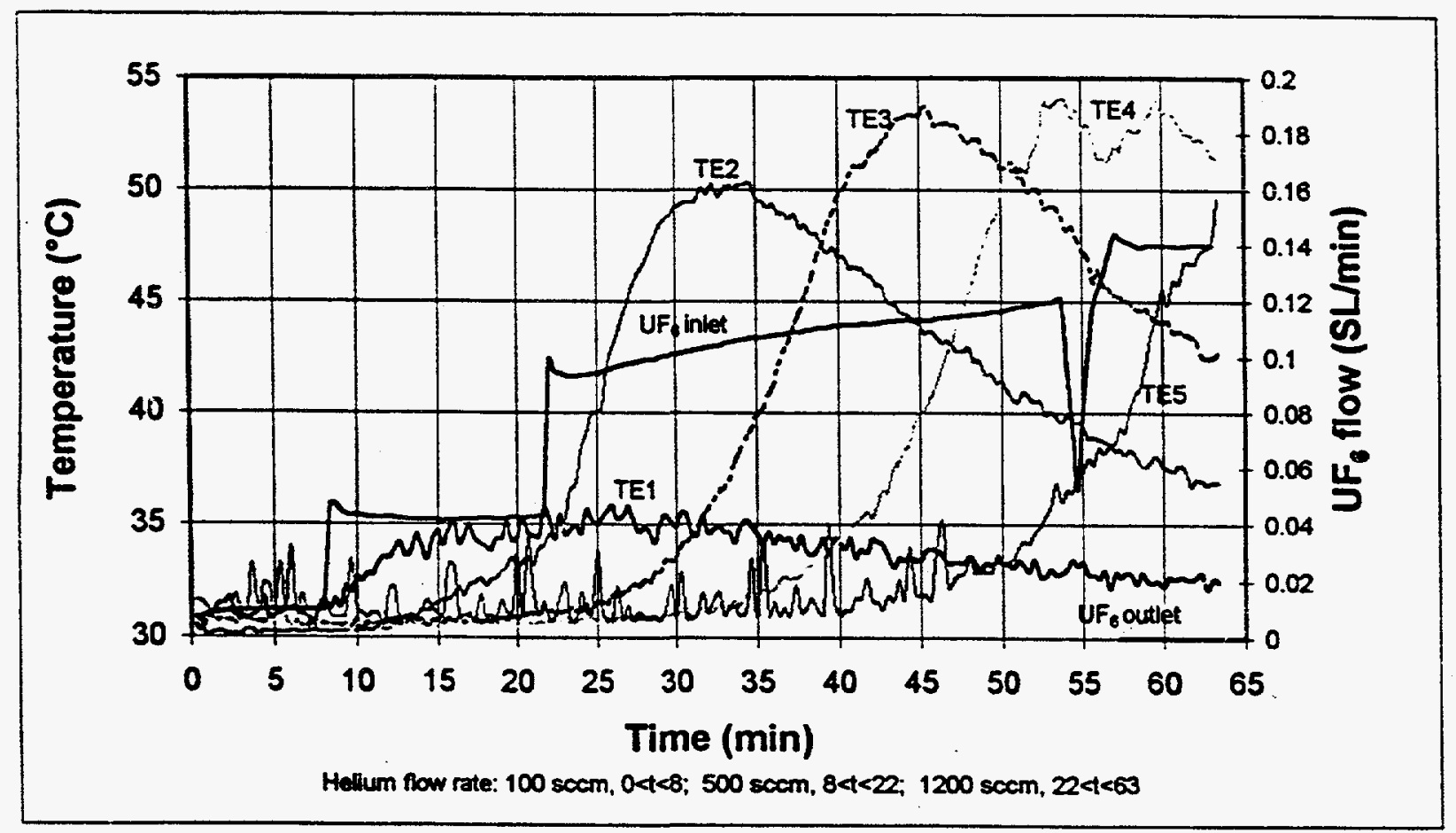

Fig. 10. Skin tempertures and $\mathrm{UF}_{6}$ flow rate vs time, 1-in. NaF trap, February 9, 1996.

As depicted, breakthrough of the trap was observed prior to reaching a peak temperature at the top of the trap. This demonstrates that the reaction front in the $\mathrm{NaF}$ trap is broader than that of the alumina trap. This is consistent with the smaller free energy change $(\Delta G)$ associated with the NaF/UF 6 reaction (or chemisorption): ${ }^{3}$ 


$$
\begin{gathered}
U F_{6}+N a F=N a F \cdot U F_{6} \quad \Delta G \approx-131 \mathrm{~kJ} / \mathrm{mol} U F_{6} \text { at } 25^{\circ} \mathrm{C} \\
\frac{1}{3} \mathrm{Al}_{2} \mathrm{O}_{3}+F_{2}=\frac{2}{3} A l F_{3}+\frac{1}{2} O_{2} \quad \Delta G \approx-448 \mathrm{~kJ} / \mathrm{mol} F_{2} \text { at } 25^{\circ} \mathrm{C}
\end{gathered}
$$

The smaller free energy change, along with lower concentrations of $U F_{6}$ and slower kinetics, is responsible for the broader, less intense thermal reaction front seen in the $\mathrm{NaF}$ bed.

The measured loading of $\mathrm{UF}_{6}$ onto the $\mathrm{NaF}$ was $74.8 \mathrm{~g}$, which corresponds $0.78 \mathrm{~g} \mathrm{UF} / \mathrm{g} \mathrm{NaF}$. The loading of $U_{6}$ was also determined by integrating the $U_{6}$ flow rate (UF $F_{6}$ concentration/total flow) over the length of the run. The loading obtained by integration was $75.1 \mathrm{~g}$ of $\mathrm{UF}_{6}$. This excellent mass balance provides good confidence in the FTIR as a quantitative tool for determining UF 6 loading. This loading also was consistent with the $1.15 \mathrm{~g} \mathrm{UF}_{6} / \mathrm{g} \mathrm{NaF}$ loading achieved in a 24-h equilibrium test performed earlier.

A desorption test was performed on this material, but was only partially successful. This was because the vessel used for desorption, thought to be nickel, was actually stainless steel. The steel suffered severe corrosion, forming $\mathrm{CrF}_{3}$. The presence of $\mathrm{CrF}_{3}$ made a weight loss desorption analysis impossible.

\section{SIMPLE INTEGRATED TEST (SIT)}

This test was designed to test key process components without excess system hardware. It was run under conditions very similar to those in the fluorine tests previously described. Table 13 shows the run parameters and results. The gas flow rates were adjusted, as when the alumina internal thermocouple reading the highest temperature (i.e., the location of the front) reached a peak. Figures 11 and 12 show temperatures on the $\mathrm{NaF}$ and alumina trap, respectively. The maximum temperatures on the $\mathrm{NaF}$ and alumina were 55 and $530^{\circ} \mathrm{C}$, respectively. The alumina trap was not surrounded by a carrier during this run, which explains the lower temperatures observed. The overall loading of $U_{6}$ was $1273 \mathrm{~g}$. (67.5 wt \%). This result is reasonably close to that obtained in the 1 -in. trap test. The slightly lower loading 
percentage could be partially due to the earlier shutdown after breakthrough. The alumina loading was $410 \mathrm{SL}$ of $\mathrm{F}_{2}$, or $0.298 \mathrm{~L} / \mathrm{g}$ of alumina. This represents $\sim 65 \%$ of the expected capacity based on the fluorine test 3 (Table 9).

Table 13. Test conditions for the simple integrated test (SIT)

\begin{tabular}{ll}
\hline NaF loaded & $1886 \mathrm{~g}$ \\
Alumina loaded & $1377 \mathrm{~g}$ \\
$\mathrm{~F}_{2}$ flow rate & $0.56 \mathrm{SL} / \mathrm{min}$ for $<1.5 \mathrm{~h}$ \\
& $0.74 \mathrm{SL} / \mathrm{min}$ for $1.5-6.1 \mathrm{~h}$ \\
& $0.93 \mathrm{SL} / \mathrm{min}$ for $6.1-9.0 \mathrm{~h}$ (end) \\
He flow rate & Equal to $\mathrm{F}_{2}$ flow \\
$\mathrm{UF}_{6}$ partial pressure & $56-79$ torr \\
$\mathrm{UF}_{6}$ loaded & $1273 \mathrm{~g}$ or $0.675 \mathrm{~g} \mathrm{UF} / \mathrm{g} \mathrm{NaF}$ \\
$\mathrm{F}_{2}$ reacted & $410 \mathrm{SL}$ or $0.298 \mathrm{~L} / \mathrm{g}$ alumina \\
Maximum NaF temperature & $55^{\circ} \mathrm{C}$ \\
Maximum alumina temperature & $533^{\circ} \mathrm{C}$ \\
\hline
\end{tabular}

After achieving breakthrough, the $\mathrm{NaF}$ trap was replaced by the alumina trap to test the direct loading of $\mathrm{UF}_{6}$ onto alumina. The conditions and results of this test are shown in Table 14: $154 \mathrm{~g}$ of $\mathrm{UF}_{6}$ was adsorbed by the alumina trap, but there was partial breakthrough before this quantity of $\mathrm{UF}_{6}$ was loaded. The $\mathrm{UF}_{6}$ breakthrough was not immediately obvious because the $\mathrm{UF}_{6}$ reacted with water generated by dehydration of alumina. This formed $\mathrm{UO}_{2} \mathrm{~F}_{2} \bullet x \mathrm{H}_{2} \mathrm{O}$ in the trap, some of which was carried into the downstream piping. Therefore, although uranium had penetrated the alumina trap, it was not detected in the FTIR cell because no $\mathrm{UF}_{6}$ was present. The test was ended when a plug of $\mathrm{UO}_{2} \mathrm{~F}_{2}$ formed in the inlet valve to the FTIR.

Upon completion of the test, it was noticed that light transmission through the $20-\mathrm{cm}$ cell (downstream cell) had decreased by two orders of magnitude. It was determined that this was caused by the reaction of aqueous HF, released from the alumina trap, with the $\mathrm{ZnSe}$ cell windows. This attack clouded the windows and greatly reduced their transparency. The windows were replaced prior to additional testing. 


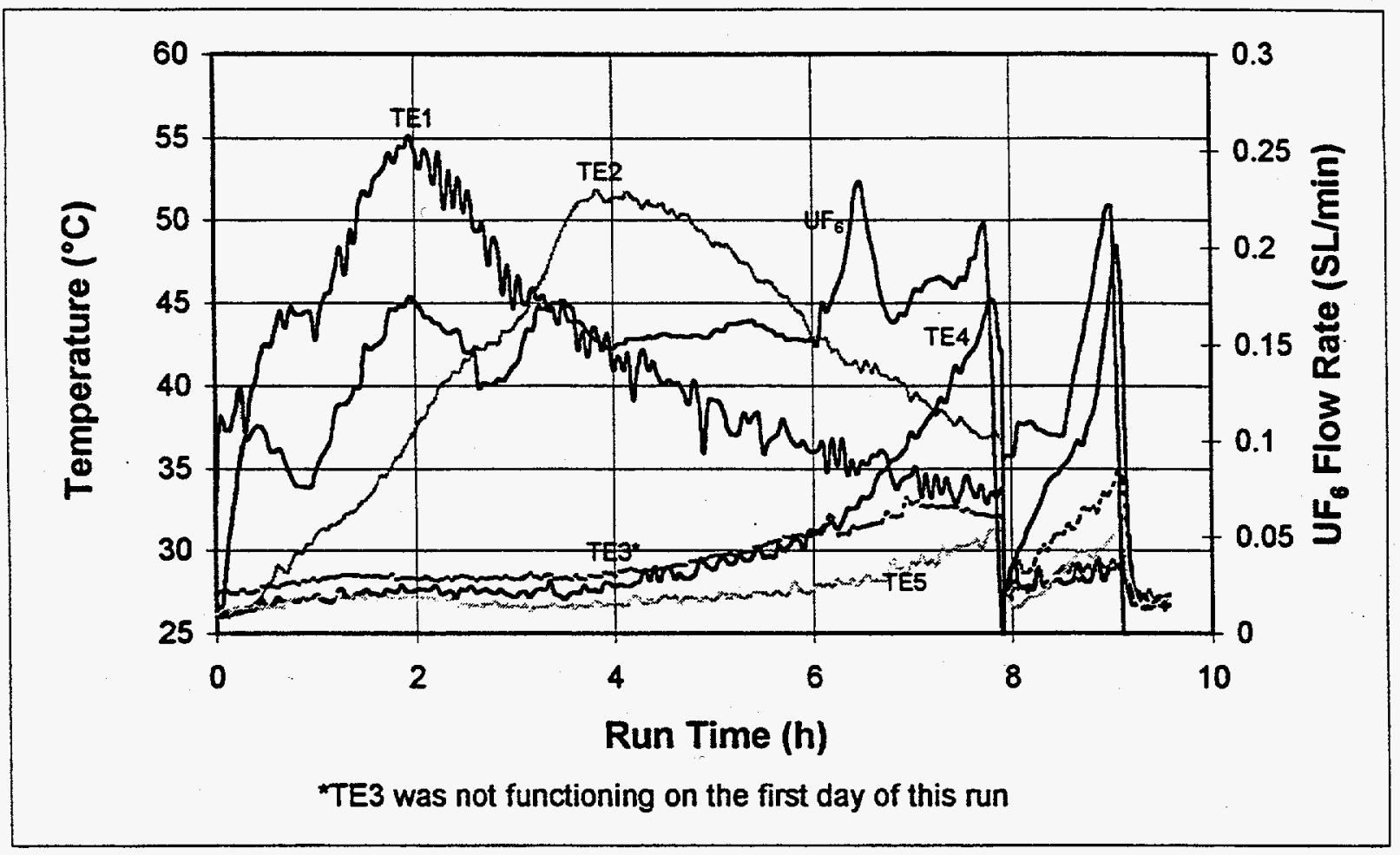

Fig. 11. Sodium fluoride temperatures and $U_{6}$ flow rate, SIT.

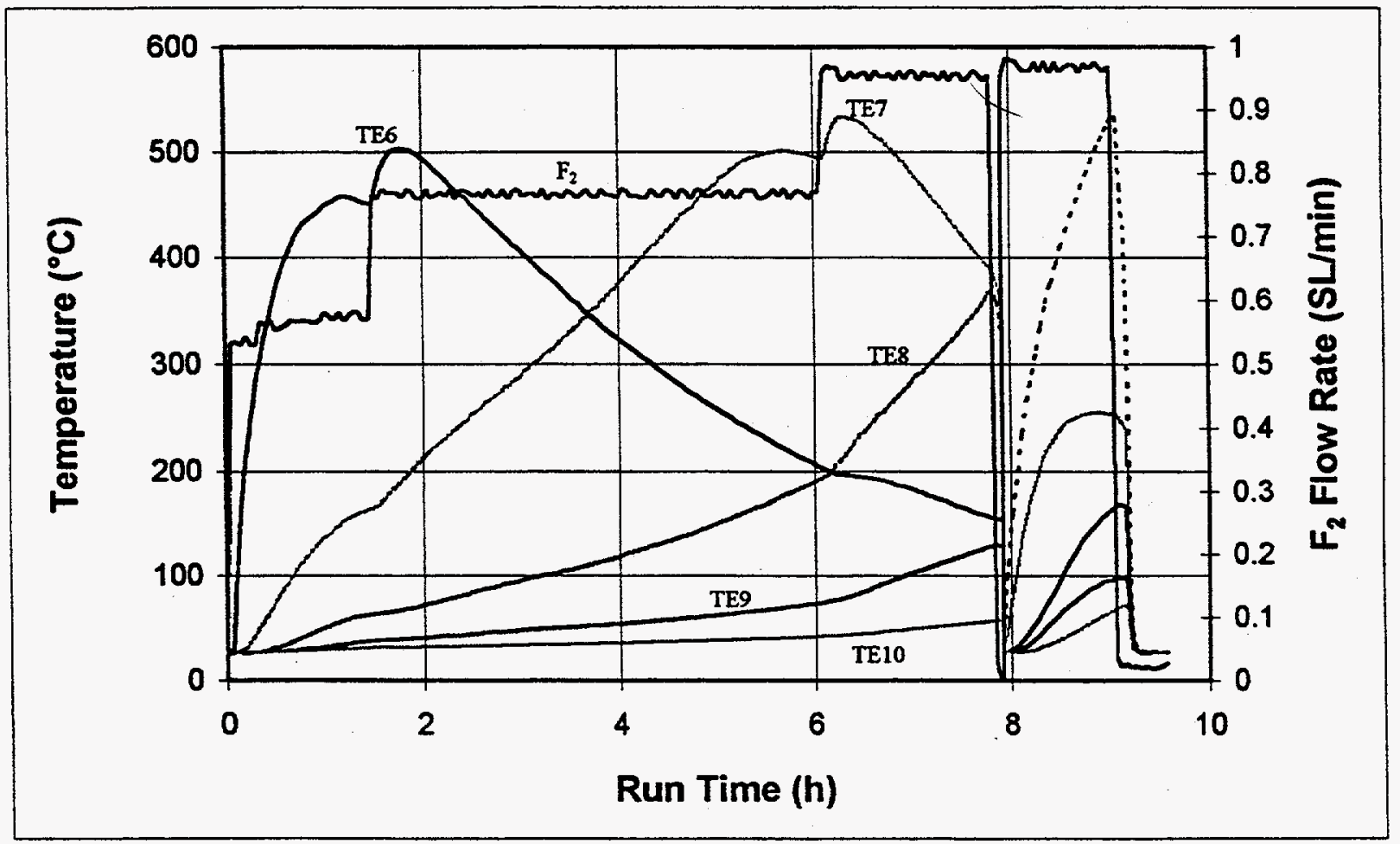

Fig. 12. Alumina internal temperatures and $\mathrm{F}_{2}$ flow rate, SIT. 


\begin{tabular}{ll}
\hline Helium and fluorine flow rate & $1.0 \mathrm{SL} / \mathrm{min}$ each \\
Time & $46 \mathrm{~min}$ \\
$\mathrm{UF}_{6}$ partial pressure & $\sim 70 \mathrm{torr}$ (average) \\
Weight change & $200 \mathrm{~g}$ \\
Weight of $\mathrm{F}_{2}$ added & $79.5 \mathrm{~g}$ \\
Weight of $\mathrm{O}_{2}$ released & $33.5 \mathrm{~g}$ \\
Weight of $\mathrm{UF}_{6}$ loaded & $154 \mathrm{~g}$ \\
\hline
\end{tabular}

The NaF loaded with $\mathrm{UF}_{6}$ from this test was tested again for desorption. This desorption cycle was carried out using the actual $\mathrm{NaF}$ trap. The process removed $99.3 \mathrm{wt} \%$ of the loaded $\mathrm{UF}_{6}$, leaving only $8.7 \mathrm{~g}$ on the trap. While the desorption was successful, it was also very slow (approximately $30 \mathrm{~h}$ ). The desorption was performed by heating the trap up to between 300 and $400^{\circ} \mathrm{C}$ and flowing helium with $1-4 \%$ fluorine through the system at between 0.3 and 0.8 SLM. The exit gas was transferred through a heated line back to the $\mathrm{UF}_{6}$ saturator, which was cooled with liquid nitrogen to recover the $\mathrm{UF}_{6}$. The process was monitored using the FTIR cells to ensure that desorption was complete and that little UF 6 bypassed the saturator. Larger flow rates could not be used since high residence time was required to saturate the gas with $\mathrm{UF}_{6}$; faster rates also tended to cause plugging at the saturator inlet.

\section{GLOVE BOX TESTS}

These tests used roughly the same configuration as the simple integrated test with the exception that the MSRE traps were located inside the glove box with all of its associated piping ${ }^{4}$ (MSRE drawing no. X3E020794A023). These tests were divided into two categories: positive pressure and vacuum. The first were operated at positive pressure, with the exhaust gases being released to the hood. The vacuum tests operated at subatmospheric pressures, and the exhaust gases were collected in an evacuated tank.

\subsection{POSITIVE PRESSURE FLOW TESTS (GBTP)}

The positive pressure flow trials were performed first. In addition to the glove box piping, a molecular sieve trap was placed downstream of the alumina trap. All lines between these two traps were 
heated to $\sim 120^{\circ} \mathrm{C}$. The purpose of these additions was to keep HF and water generated in the alumina trap in the form of vapors until they reached the molecular sieve, where they would be adsorbed. The copper valves stems on the alumina trap outlet valve and on the molecular sieve inlet valve were gold plated to protect them from corrosion by HF. Included in the glove box setup were three nondestructive analysis (NDA) detectors, located in the bottom, middle, and top of the trap. These detectors measured the increased attenuation of gamma rays, across the trap, from $\mathrm{a}^{57} \mathrm{Co}$ source as the reaction front passed its location on the trap. ${ }^{6}$ Table 15 shows the relative positions of the thermocouples and NDA detectors on the alumina trap. Also added was a mass flowmeter at very end of the system. Its purpose was to determine if the oxygen generation in the fluorine trap was actually half of the fluorine input. However, there were difficulties in recording data from the flowmeter, and its output was not used in these tests.

Table 15. Axial positioning of thermocouples and NDA detectors on gas traps ${ }^{a}$

\begin{tabular}{lllllllllll}
\hline Instrument & Bottom & NDA1 & TC1 & TC2 & NDA2 & TC3 & TC4 & NDA3 & TC5 & Top \\
Position (in.) & 0 & .28 & .43 & 4.01 & 6.376 & 7.59 & 11.2 & 12.48 & 14.8 & 15.1 \\
\hline
\end{tabular}

When the NaF trap was first attached to the system and the line was fluorinated, $\mathrm{HF}$ and water were observed. This indicated that moisture had somehow penetrated the NaF trap. The moisture and HF that came off the NaF trap damaged the $10-\mathrm{cm}$ cell windows. To change the cell windows, the back plate had to be removed from the glove box. The trap was removed and heated to roughly $200^{\circ} \mathrm{C}$ to remove the moisture. This indicates the importance of confirming and maintaining the dryness of the $\mathrm{NaF}$ in the traps, since changing the cell windows is a major task that requires breaking both primary and secondary containment.

Upon reinstalling the cells and the $\mathrm{NaF}$ trap, a restriction was identified by a pressure differential across the trap. The trap was again removed, and the inlet and outlet lines on the trap were rodded out. The pressure drop across the trap disappeared, but liquid was observed exiting the outlet line of the trap. Apparently all of the aqueous HF had not been removed in the first treatment. It was then decided to subject the trap to the same conditions used for initial NaF treatment. The trap was reconnected to the system and prepared for the next run. This was done on a weekend so there was a 2-day lag between connecting the trap and starting the test.

When the test was initiated, a restriction was observed and was again traced to the NaF trap. The system was evacuated and then pressurized to 100 psia in an attempt to dislodge the partial plug, but this 
process was not successful. The run was then continued at a much slower rate of $\mathrm{UF}_{6}$ loading. Table 16 shows run parameters and approximate pressure drops across the $\mathrm{NaF}$ trap. The second increase in pressure during the first day of testing occurred when the trap was mechanically vibrated in an attempt

Table 16. Parameters for GBTP ${ }^{a}$

\begin{tabular}{llllll}
\hline Date & $\begin{array}{l}\mathrm{F}_{2} \text { flow } \\
(\mathrm{SL} / \mathrm{min})\end{array}$ & $\begin{array}{l}\text { He flow } \\
(\mathrm{SL} / \mathrm{min})\end{array}$ & $\begin{array}{l}\text { UF } \\
(\mathrm{SL} / \mathrm{min})\end{array}$ & Duration $(\mathrm{h})$ & $\sim \Delta \mathrm{P}$ (torr) \\
\hline $3 / 25 / 96$ & 0.56 & 0.6 & 0.061 & 2.5 & 750 \\
& 0.74 & 0.8 & 0.065 & 1.5 & 1250 \\
& 0.74 & 0.8 & 0.047 & 2.5 & 1750 \\
$3 / 26 / 96$ & 0.74 & 0.8 & 0.041 & 3 & 2100 \\
& 0.35 & 1.21 & 0.052 & 4.5 & 1550 \\
$3 / 27 / 96$ & 0.15 & 1.45 & 0.054 & 9.5 & 1300 \\
$3 / 28 / 96$ & 0 & 1.61 & 0.058 & 4 (breakthrough) & 1150 \\
\hline
\end{tabular}

${ }^{a}$ Weight of $\mathrm{NaF}=2003.5 \mathrm{~g}$; weight of alumina $=1387.2 \mathrm{~g}$.

to remove the restriction. When the inlet piping was not heated to increase the vapor pressure of $U_{6}$, the high upstream pressure prevented loading a high $\mathrm{UF}_{6}$ concentration (Figs. A.36, A.38, A.40, and A.42, see Appendix A). This fact extended the required loading time to 4 days and lowered the peak temperatures observed on the $\mathrm{NaF}$ trap. The fluorine trap behaved normally, but reached much lower temperatures than in past tests, as the fluorine concentration was low throughout the run. Table 17 shows the maximum temperatures observed in the two traps (Figs A.36-A.43 in Appendix A) and $U_{6}$ and $F_{2}$ loadings. The $\mathrm{UF}_{6}$ loading on the trap was quite high during this run ( $1450 \mathrm{~g}$, or $\left.0.74 \mathrm{~g} \mathrm{UF}_{6} / \mathrm{g} \mathrm{NaF}\right)$ and can be attributed to the slow loading rate, which produced a very narrow front. As Fig. 13 shows, UF 6 breakthrough was detected at very low concentrations. At the helium flow rate used during this run (1.6 SLM), the $\mathrm{UF}_{6}$ flow rate of 0.0001 SLM corresponds to $60 \mathrm{ppm}$. The area under the breakthrough curve represents less than $45 \mathrm{mg}$ of ${ }^{238} \mathrm{U}$ using the conservative calibration curve developed in Sect. 6 (see Fig. A.35 in Appendix A). This is over a 30-min period from the time breakthrough was detected. The NDA measurements showed a significant decrease in gamma-ray transmission through the bed when the $\mathrm{UF}_{6}$ front passed the detection zone (Fig. 14). The relative decrease in counts is the important analytical feature. The absolute transmission depends on trap orientation and pellet-packing density in the detection zone, and it will probably be different for each trap. 

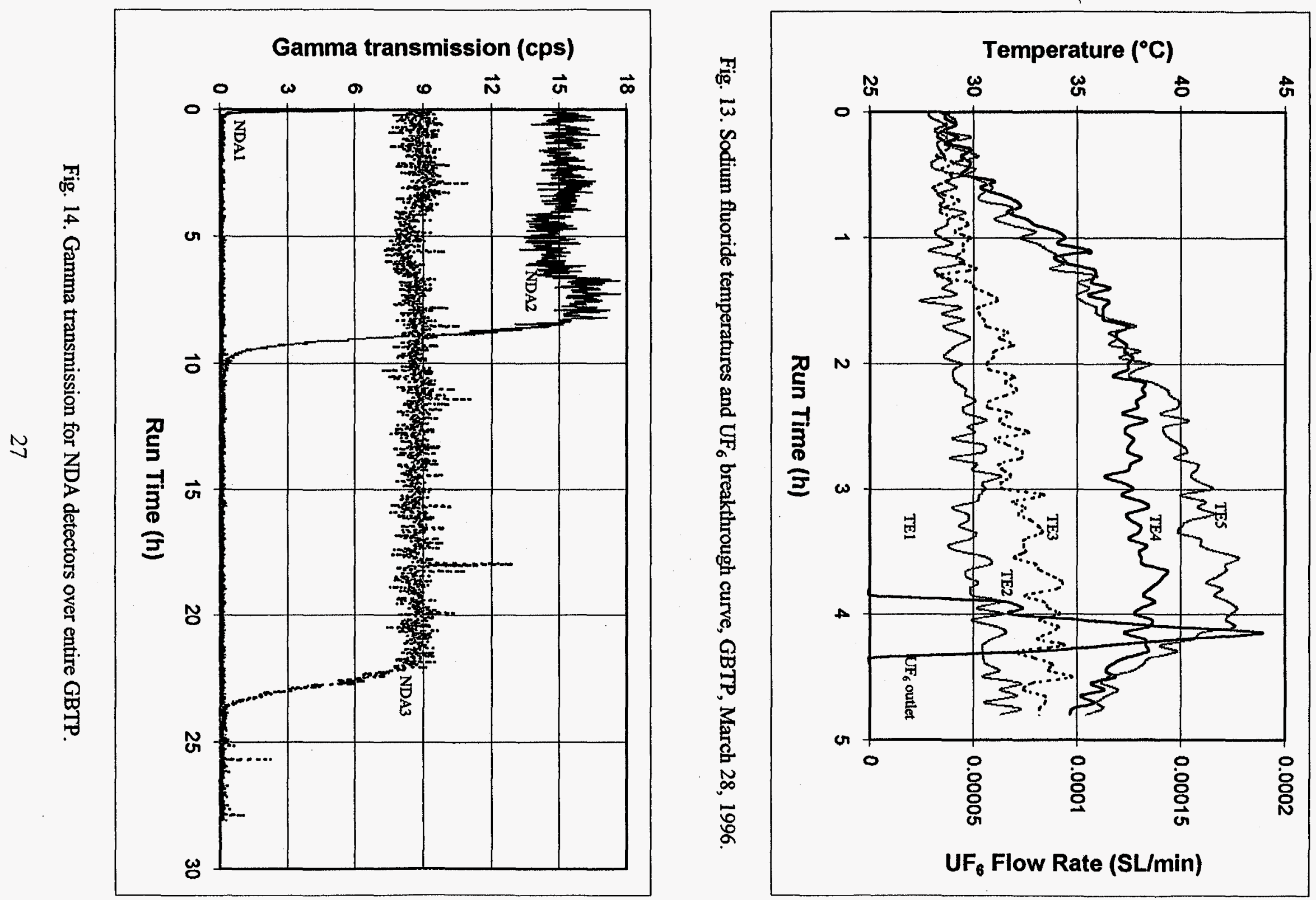
Table 17. Maximum $\mathrm{NaF}$ and alumina temperatures and $\mathrm{UF}_{6}$ and $\mathrm{F}_{2}$ loading for GBTP

\begin{tabular}{|c|c|c|c|c|c|c|}
\hline \multirow[b]{2}{*}{ Date } & \multicolumn{2}{|c|}{ Maximum temperature } & \multicolumn{2}{|c|}{$\mathrm{UF}_{6}$ loading } & \multicolumn{2}{|c|}{$\mathrm{F}_{2}$ loading } \\
\hline & $\mathrm{NaF}\left({ }^{\circ} \mathrm{C}\right)$ & $\begin{array}{l}\text { Alumina } \\
\left({ }^{\circ} \mathrm{C}\right)\end{array}$ & $\begin{array}{c}\text { By flow } \\
\text { (g) }\end{array}$ & $\begin{array}{c}\text { By wt } \\
\text { (g) }\end{array}$ & $\begin{array}{c}\text { By flow } \\
\text { (SL) }\end{array}$ & $\begin{array}{c}\text { By wt } \\
\text { (SL) }\end{array}$ \\
\hline $3 / 25 / 96$ & 53 & 627 & 352 & & 266 & \\
\hline $3 / 26 / 96$ & 40 & 500 & 333 & & 232 & \\
\hline $3 / 27 / 96$ & 42 & 176 & 492 & & 86 & \\
\hline $3 / 28 / 96$ & 43 & 32 & 234 & & 0 & \\
\hline Total & & & 1411 & 1430 & 584 & 568 \\
\hline
\end{tabular}

Upon completion of this test, the tubing downstream of the alumina trap was rinsed with $100 \mathrm{~mL}$ of deionized water. The resulting solution was analyzed for uranium as well as other metal ions by inductively coupled plasma emission spectrometry (ICP). The results are shown in Table 18 . The $1.5 \mathrm{ppm}$ of uranium found accounts for almost all of the uranium present, since $\mathrm{UO}_{2} \mathrm{~F}_{2}$ is very soluble in water. This translates to a total of $\sim 0.15 \mathrm{mg}$ of uranium. The content of other metals is negligible. Values for silver probably represent an error in the report since there is no known source of silver.

\subsection{VACUUM TESTS (GBTV)}

For the vacuum-draw trials, two modifications were made to the system. A 4-m-long FTIR cell was added downstream of the molecular sieve trap, and an evacuated liquid nitrogen tank $(\sim 172 \mathrm{~L})$ was added at the end of the system. These tests were run in batches that brought the evacuated tank up to a specified pressure before they were terminated. Several conditions were tested, including high concentrations of fluorine and $\mathrm{UF}_{6}$ and low differential pressures, to observe the effects on trap loading and trap temperatures. Four runs were completed. Table 19 gives a summary of the parameters for each run; Table 20 shows the maximum temperatures observed in the two traps and $U F_{6}$ and $F_{2}$ loadings. Table 21 displays the initial and final system pressures for each batch. By following the location of the maximum trap temperatures, one can track the movement of the reaction front. The first batch was 
Table 18. Metals analysis of downstream piping wash (GBTP) ${ }^{a}$

\begin{tabular}{lc}
\hline Metal & $\begin{array}{c}\text { Result } \\
(\mathrm{mg} / \mathrm{L})\end{array}$ \\
\hline $\mathrm{Ag}$ & 50.0 \\
$\mathrm{Al}$ & 0.20 \\
$\mathrm{As}$ & $<0.05$ \\
$\mathrm{~B}$ & $<0.08$ \\
$\mathrm{Ba}$ & 0.028 \\
$\mathrm{Be}$ & $<0.001$ \\
$\mathrm{Ca}$ & 0.16 \\
$\mathrm{Cd}$ & $<0.005$ \\
$\mathrm{Co}$ & $<0.004$ \\
$\mathrm{Cr}$ & $<0.004$ \\
$\mathrm{Cu}$ & 1.3 \\
$\mathrm{Fe}$ & $<0.05$ \\
$\mathrm{Li}$ & $<0.005$ \\
$\mathrm{Mg}$ & 0.063 \\
$\mathrm{Mn}$ & 0.094 \\
$\mathrm{Mo}$ & $<0.040$ \\
$\mathrm{Na}$ & 0.47 \\
$\mathrm{Ni}$ & 0.83 \\
$\mathrm{P}$ & $<0.30$ \\
$\mathrm{~Pb}$ & $<0.050$ \\
$\mathrm{Sb}$ & 0.22 \\
$\mathrm{Se}$ & $<0.050$ \\
$\mathrm{Si}$ & $<0.20$ \\
$\mathrm{Sn}$ & $<0.05$ \\
$\mathrm{Sr}$ & $<0.005$ \\
$\mathrm{Ti}$ & $<0.02$ \\
$\mathrm{U}$ & 1.5 \\
$\mathrm{~V}$ & $<0.002$ \\
$\mathrm{Zn}$ & 0.037 \\
$\mathrm{Zr}$ & $<0.020$ \\
\hline$a \mathrm{Analysis}$ Procedure No $\mathrm{EPA}$ & 200.7 \\
\hline
\end{tabular}

${ }^{a}$ Analysis Procedure No. EPA 200.7. 
Table 19. Parameters for GBTV ${ }^{a}$

\begin{tabular}{lllll}
\hline Date & $\mathrm{F}_{2}$ flow $(\mathrm{SL} / \mathrm{min})$ & He flow (SL/min) & $\mathrm{UF}_{6}$ flow, av (SL/min) & Duration $(\mathrm{h})$ \\
\hline \multirow{2}{*}{$4 / 9 / 96$} & 0.92 & 1.00 & 0.136 & 1.25 \\
& $0.76-0.72^{b}$ & $0.82-0.71^{b}$ & 0.134 & 0.65 \\
$4 / 10 / 96$ & $0.47-0.57^{c}$ & $0.24-0.33^{c}$ & 0.099 & 2.15 \\
& 0.99 & 0.48 & 0.104 & 0.95 \\
& 0.99 & 0 & 0.085 & 0.90 \\
$4 / 11 / 96$ & 0.42 & 0 & 0.117 & 0.63 \\
& 0.59 & 0 & 0.240 & 0.87 \\
& 0.41 & 0 & 0.327 & 0.23 \\
& 0.41 & 0 & 0.113 & 1.47 \\
$4 / 12 / 96$ & $0.09-0.46^{d}$ & 0 & 0.029 & 4.43 \\
\hline
\end{tabular}

Weight of $\mathrm{NaF}=1814 \mathrm{~g}$; weight of alumina $=1407 \mathrm{~g}$.

${ }^{b}$ The fluorine and helium flows were set; the initial value listed indicates this setting. Flows decreased to the second value shown as the pressure drop decreased.

Flow rates were controlled with valves on the inlet to the saturator (to keep upstream pressure lower). As pressure drop through the system varied, this valve had to be adjusted, which is the reason for the range of flow rates.

"There was a large restriction in the process piping during this batch, and the fluorine flow had to be constantly adjusted to keep the pressure from rising too high.

operated under conditions similar to the ones used in previous tests, with a 50/50 mix of helium and fluorine at relatively high flows.

In the second batch the flowmeter measuring the exiting gases was operational. Its readings were used to calculate the oxygen generation rate, which was expected to be $50 \%$ of the fluorine flow rate.

This was done by comparing calculated flow rates with actual measured flow rates, as well as comparing calculated pressure rise in the evacuated tank with the actual pressure between two thermocouple positions. The actual "hot spot" in the trap can then be hotter than the temperature at the thermocouple position. Figures 15 and 16 give trap temperature profiles along with $U F_{6}$ and $F_{2}$ flow rates (refer also to Figs. A.50 and A.51, see Appendix A). The readings were corrected according to the different thermal conductivities of the gases being measured. As Fig. A.50 (Appendix A) depicts, the correlation between "corrected" measured flow rates and the calculated flow rates is very good. If the $\mathrm{O}_{2}$ generation is assumed to be $50 \mathrm{~mol} \%$ of the $\mathrm{F}_{2}$ flow, then the second flowmeter allows for an independent measurement of the $\mathrm{F}_{2}$ concentration (see Appendix $\mathrm{C}$ ).

In the third batch the uranium concentration was increased significantly with respect to previous tests. The remainder of the gas was $F_{2}$, to simulate what is expected during later runs of the RGRS. This 
was the first test in which the inlet line was heated. In the test system a large upstream pressure was necessary to obtain the desired flow rates due to the pressure drop over $30 \mathrm{ft}$ of 0.25 -in. tubing on the

Table 20. Maximum temperatures and $\mathrm{UF}_{6}$ and $\mathrm{F}_{2}$ loading in GBTV

\begin{tabular}{|c|c|c|c|c|c|c|c|}
\hline \multirow[b]{2}{*}{ Date } & \multirow{2}{*}{$\begin{array}{l}\text { Duration } \\
\text { (h) }\end{array}$} & \multicolumn{2}{|c|}{ Maximum temperature } & \multicolumn{2}{|c|}{$\mathrm{UF}_{6}$ loading (g) } & \multicolumn{2}{|c|}{$\mathrm{F}_{2}$ loading (SL) } \\
\hline & & $\operatorname{NaF}\left({ }^{\circ} \mathrm{C}\right)$ & Alumina $\left({ }^{\circ} \mathrm{C}\right)$ & By flow & By wt & By flow & By wt \\
\hline \multirow[t]{2}{*}{$4 / 9 / 96$} & 1.25 & 54 & 698 & 160 & & 73 & \\
\hline & 0.65 & 55 & $700^{a}$ & 81 & & 24 & \\
\hline \multirow[t]{3}{*}{$4 / 10 / 96$} & 2.15 & 43 & 398 & 203 & & 71 & \\
\hline & 0.95 & 49 & $570^{b}$ & 94 & & 56 & \\
\hline & 0.90 & 51 & 745 & 73 & & 51 & \\
\hline \multirow[t]{4}{*}{$4 / 11 / 96$} & 0.63 & 39 & 308 & 69 & & 17 & \\
\hline & 0.87 & 57 & 473 & 197 & & 30 & \\
\hline & 0.23 & 64 & $420^{c}$ & 71 & & 6 & \\
\hline & 1.47 & $70^{d}-62^{c}$ & $380^{c}$ & 157 & & 36 & \\
\hline $4 / 12 / 96$ & 4.43 & 37 & 300 & $120^{a}$ & & 64 & \\
\hline Total & & & & 1225 & 1184 & 428 & 407 \\
\hline
\end{tabular}

${ }^{\circ}$ The temperature was initially as shown and then continuously decreased.

${ }^{\circ}$ The temperature was rapidly rising at the end of the period.

'The temperature decreased to this point and then stabilized.

${ }^{\mathrm{T}}$ The temperature increased to this point and then stabilized.

'This value is believed to be high due to the continuous plugging of the line during the run.

Table 21. Pressure measurements from GBTV

\begin{tabular}{|c|c|c|c|c|c|c|c|c|}
\hline \multirow{3}{*}{$\begin{array}{l}\text { Location } \\
\text { Date }\end{array}$} & \multicolumn{8}{|c|}{ Pressures (torr) } \\
\hline & \multicolumn{2}{|c|}{ Upstream (hood) } & \multicolumn{2}{|c|}{ 10-cm FTIR cell } & \multicolumn{2}{|c|}{ 20-cm FTIR cell } & \multicolumn{2}{|c|}{ Vacuum tank } \\
\hline & Initial & Final & Initial & Final & Initial & Final & Initial & Final \\
\hline $4 / 9 / 96$ & 1000 & $980^{a}$ & 264 & 747 & 246 & 739 & $<0.2$ & 724 \\
\hline $4 / 10 / 96$ & 540 & $930^{b}$ & 121 & 750 & 110 & 745 & $<0.2$ & 734 \\
\hline $4 / 11 / 96$ & 830 & $1450^{c}$ & 73 & 204 & 62 & 200 & $<0.2$ & 176 \\
\hline $4 / 12 / 96$ & $1900^{d}$ & 3150 & 53 & 133 & 47 & 130 & $<0.2$ & 111 \\
\hline
\end{tabular}

apressure increased to 1100 torr at end of first parameter setting (Table 19).

${ }^{\circ}$ Pressure increased to 1020 torr at end of second parameter setting (Table 19).

'Pressure increased to 2600 torr at end of second parameter setting (Table 19).

dPressure decreased to 1600 torr during times when flow rate was at the low end of the range (Table 19). 


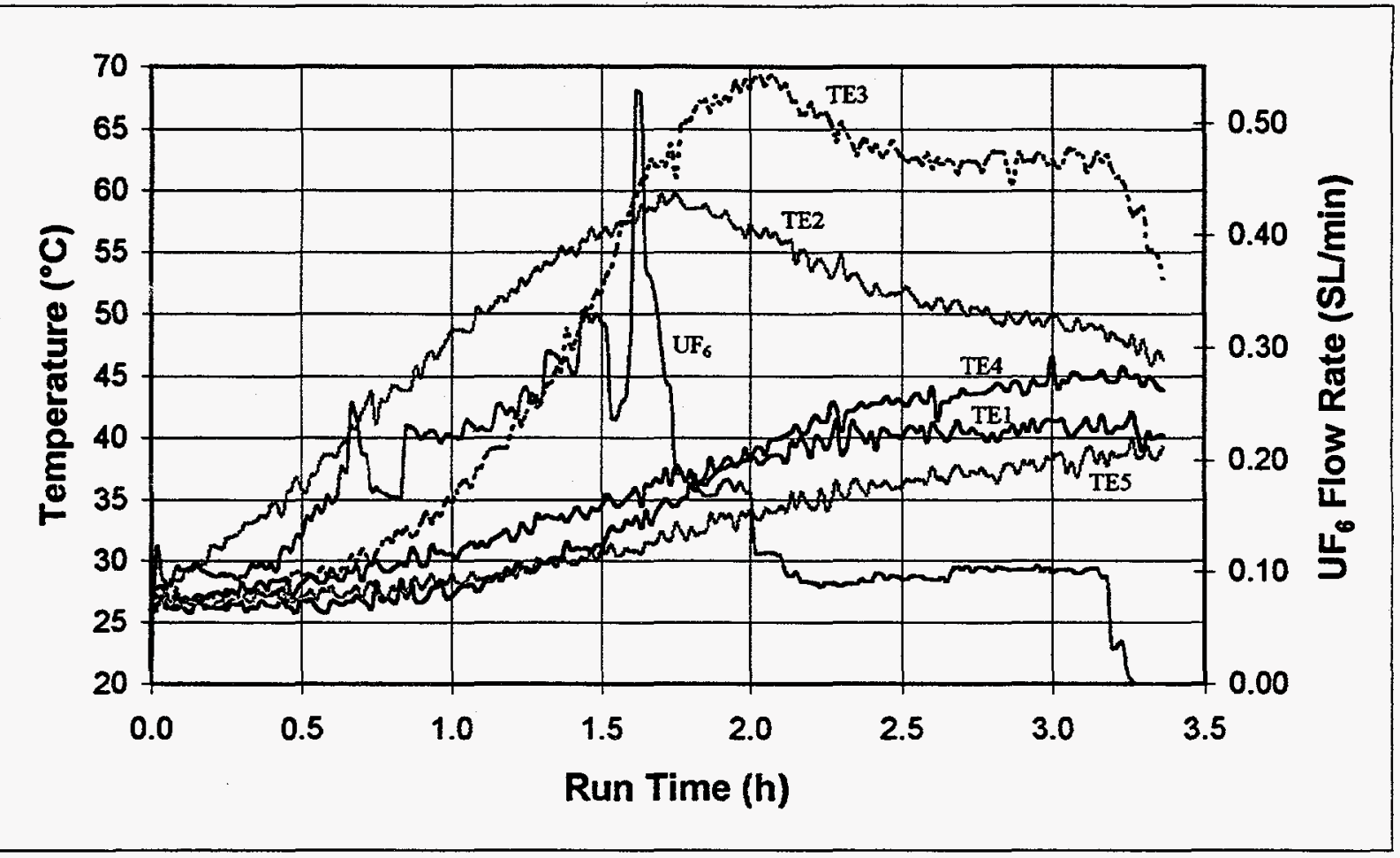

Fig. 15. Sodium fluoride temperatures and $\mathrm{UF}_{6}$ flow rate, GBTV-3, April 11, 1996.

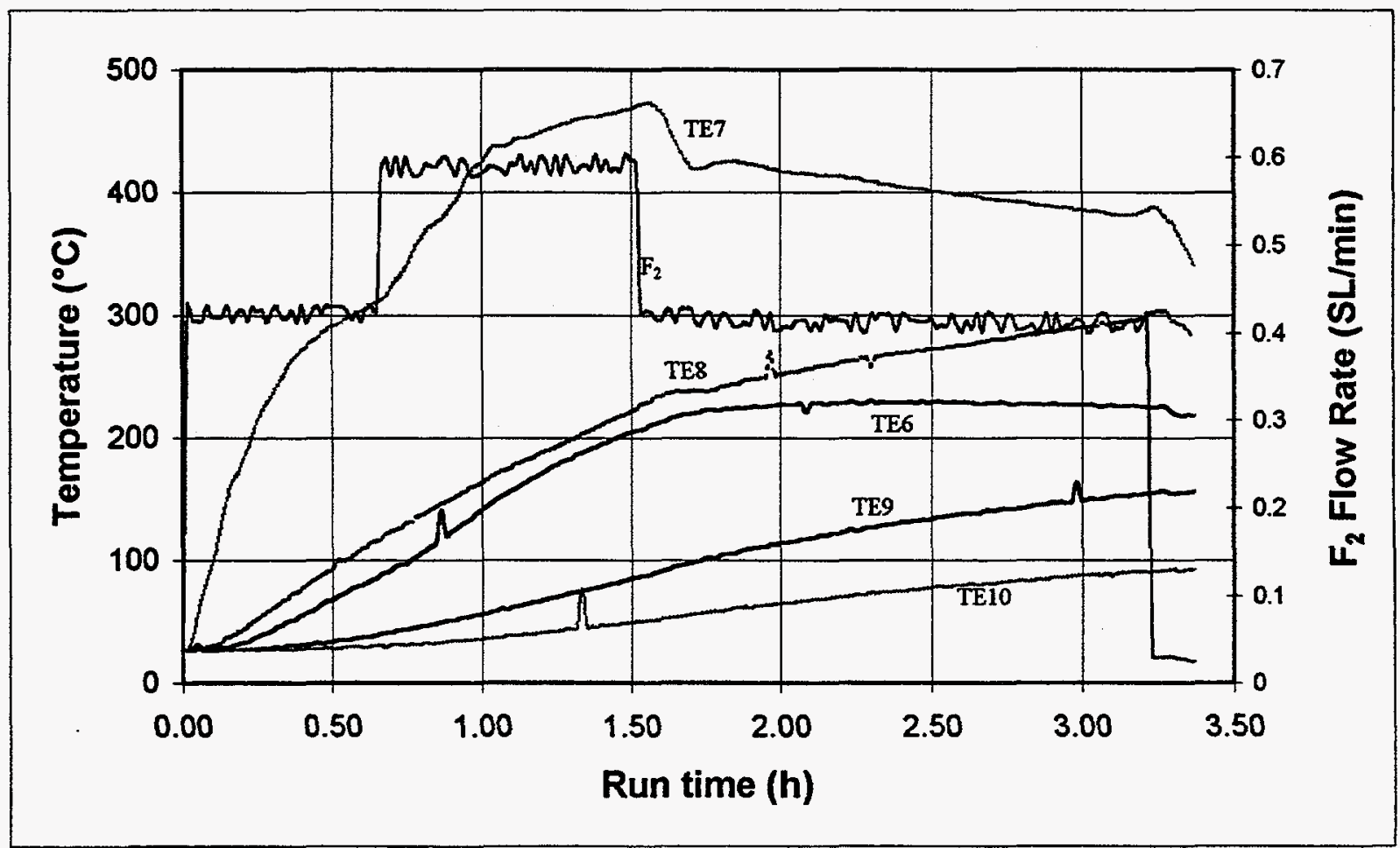

Fig. 16. Alumina temperatures and $\mathrm{F}_{2}$ flow rate, GBTV-3, April 11, 1996. 
inlet line before reaching the trap. These higher pressures required heating the inlet line to $100^{\circ} \mathrm{C}$, which is well above the design temperature to be used at $\operatorname{MSRE}\left(50^{\circ} \mathrm{C}\right)$. Lower flow rates were used in order to increase residence time in the saturator and obtain high $\mathrm{UF}_{6}$ concentrations. No problems were observed during this run, and high $U_{6}$ concentrations were readily achieved (>50 mol \%). These high $U_{6}$ flow rates produced correspondingly high temperatures on the NaF trap during loading (Fig. 15).

In the fourth batch the system was to be run at high gas velocities to determine if greater flow rates than those previously tested could be run safely. From almost the beginning of the run, it appeared that a plug of $\mathrm{UF}_{6}$ had formed that was greatly restricting, but not stopping, the flow. The run was shut down before breakthrough could occur because the loading rate of $U_{6}$ on the trap was very low. An analysis of the system after the lines were purged showed that no plugging had occurred. The inlet flowmeter/valve had failed and closed because of excessive heating. This failure was caused by the prolonged heating of the piping, as the problem was not evident during the third batch. When allowed to cool, the flowmeter functioned properly, but its calibration was upset. Further testing revealed the failure was mechanical, not electronic. (The electronics were remotely located, and the valve still closed.) The additional testing also showed that the closure occurred at temperatures in excess of $95^{\circ} \mathrm{C}$ and that it was reversible as the valve reopened after cooling down.

The spectra taken using the 4-m FTIR cell installed downstream of the molecular sieve trap showed only $\mathrm{CF}_{4}\left(\mathrm{O}_{2}, \mathrm{He}\right.$, and $\mathrm{F}_{2}$ cannot be detected by IR analysis). The molecular sieve therefore effectively removed the $\mathrm{HF}$ and $\mathrm{H}_{2} \mathrm{O}$ as expected. The $\mathrm{CF}_{4}$ is an impurity present in fluorine supply.

The overall UF 6 loading was $65.3 \mathrm{wt} \%$. The temperature profiles (Figs. 15 and A.47, the latter in Appendix A) indicated that the trap was nearly full. The only reliable NDA measurements were taken by the midposition detector (Fig. A.52, Appendix A). The loading front never reached the NDA detector at the top of the trap.

\section{ANALYSIS AND CONCLUSIONS}

The major objectives of RGRS laboratory testing were to ensure that all process equipment functioned as intended and to debug the system as much as possible when operated with surrogate $U_{6} / F_{2}$ mixtures. Several discoveries concerning the process system were made during the laboratory testing 
program. The implementations that were made as a result of these discoveries have greatly improved the safety and overall effectiveness of the RGRS. These discoveries included the following:

1. The maximum fluorine flow rate was much lower than initially anticipated. This resulted in the addition of a needle valve to the system to allow control at the lower flow rates.

2. Initially, there were continuous problems with the thermocouples (five thermocouples in one) used to measure interior temperatures in the trap. A problem was discovered with solder joints in the connectors. The solder joints were replaced with a crimped connection, which alleviated the difficulty.

3. Hydrogen fluoride and moisture were observed exiting the alumina trap. A gold-plated valve was placed on the outlet of the alumina trap to prevent corrosion from aqueous HF. A molecular sieve trap was installed downstream of the alumina trap to collect the water and HF produced, and a gold-plated valve was also installed on the trap inlet. The line between the alumina and molecular sieve traps was heated to keep the material in the vapor phase until it reached the molecular sieve trap. Finally, an HF sensor was placed downstream of the molecular sieve trap to detect the HF breakthrough.

4. A restriction in the $\mathrm{NaF}$ trap was observed, which was later determined to be caused by pellets trapped in the outlet tube. These pellets were able to bypass the baffle plates because the weld rings that were supposed to prohibit this migration were missing in some of the traps. As a result, all of the traps were cut open and weld rings were installed.

The testing also helped to debug the process monitoring equipment from problems such as stepwise temperature rising and a maximum temperature reading of $560^{\circ} \mathrm{C}$. The instrumentation for the system was checked out, and analysis equipment such as the FTIR cells and NDA detectors was proven to be effective. Temperature profiles were shown to predict the trap loading accurately.

The second objective of RGRS testing was to determine safe operating conditions for the overall process. The conditions can be summarized as follows. The overall flow rate was limited only by the fluorine concentration. (Rates up to $2.0 \mathrm{SL} / \mathrm{min}$ were tested.) The fluorine flow rate was <1.0 SLM. The operating temperature for $\mathrm{Al}_{2} \mathrm{O}_{3}$ was $<700^{\circ} \mathrm{C}$; no known limit existed for $\mathrm{NaF}$. (Temperatures up to $71^{\circ} \mathrm{C}$ were tested.) No known maximum concentration was determined for $\mathrm{UF}_{6}$; up to $54 \mathrm{~mol} \%$ was 
tested with complete success. In terms of trap loading, tests indicated that the NaF trap may be safely loaded (no detectable breakthrough) until either the top NDA detector goes to $<5 \%$ of the number of initial counts or the fourth ( $80 \%$ full) thermocouple reaches a maximum. The alumina trap can be safely loaded until the temperature of the top thermocouple surpasses that of the fourth thermocouple. This still provides protection in the event of $\mathrm{UF}_{6}$ breakthrough of the $\mathrm{NaF}$ trap. 


\section{REFERENCES}

${ }^{1}$ Nuclear Applications and Technology 8(2), 105-208 (February 1970).

${ }^{2}$ G. D. Del Cul, L. M. Toth, D. F. Williams, and S. Dai, Some Investigations on the Chemistry of Activated Charcoal with Uranium Hexafluoride and Fluorine, to be published as ORNL/TM-13052.

${ }^{3}$ L. D. Trowbridge et al., Technical Bases of Selection of Trapping Technology for the MSRE Interim Vent and Trapping Project, K/TCD-1142, August 1995.

4"MSRE Temporary Ventilation and Trap System General Arrangement Assembly," LMES Central Engineering Services Drawing No. X3E020794A023.

${ }^{5}$ R. S. McDowell, L. B. Asprey, and R. T. Paus, Journal of Chemical Physics 61, 3571-80 (1974).

${ }^{6 " M S R E ~ U F}{ }_{6}$ In Process Carrier Assembly," LMES Central Engineering Services Drawing No. X3E020794A008. 
Appendix A

ADDITIONAL FIGURES 



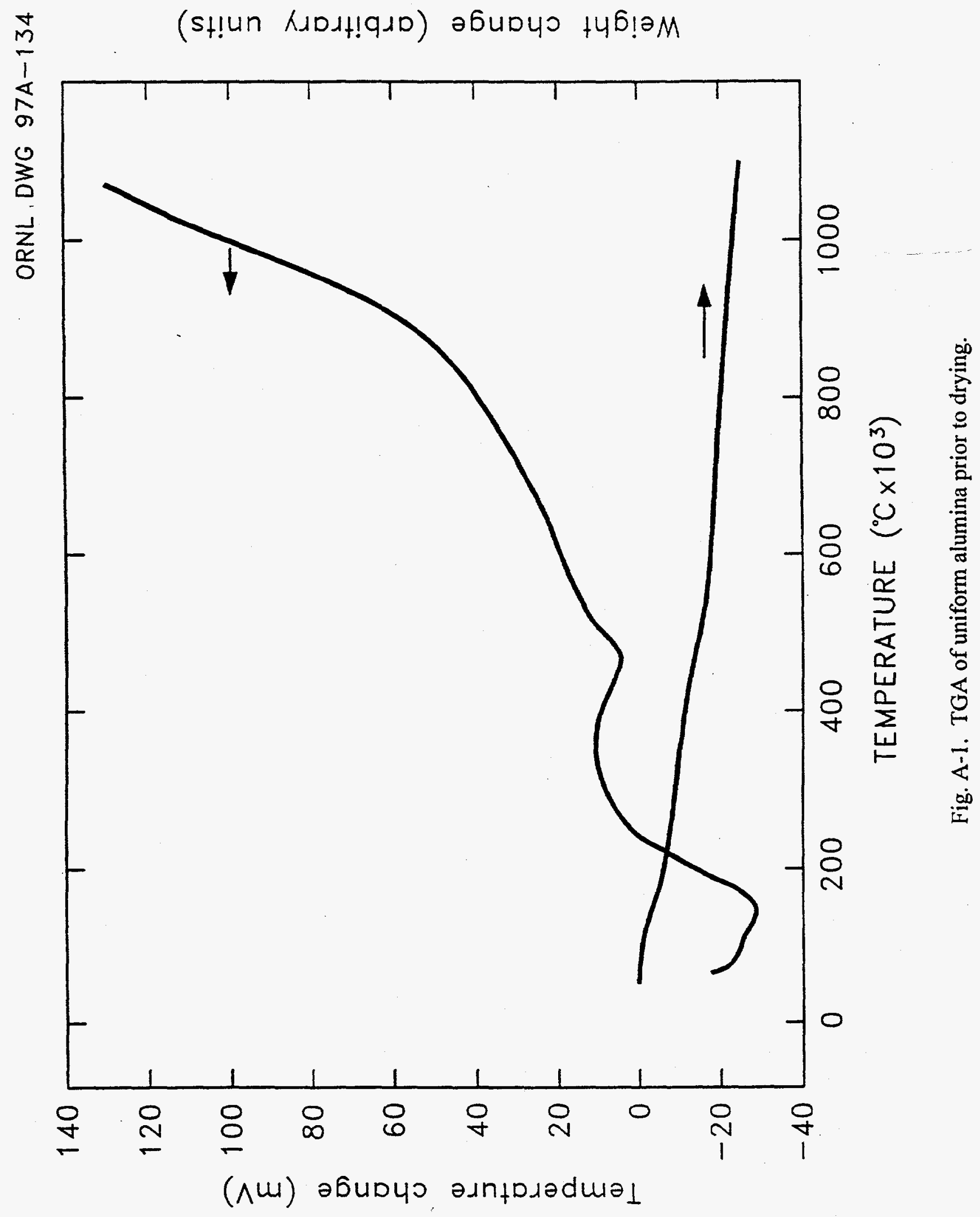




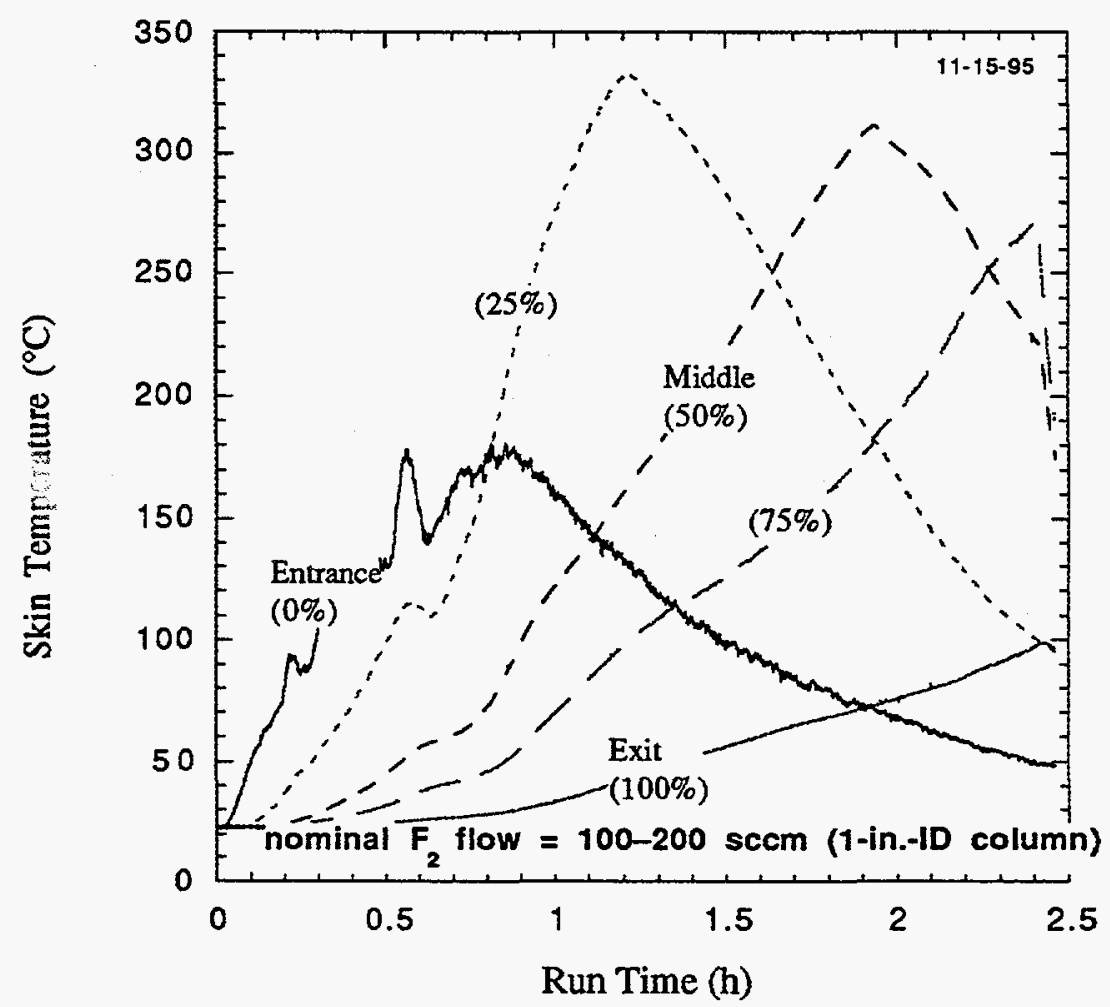

Fig. A-2. Skin temperatures for FTT-1A, 100-200 sccm fluorine, 1-in.-ID trap.

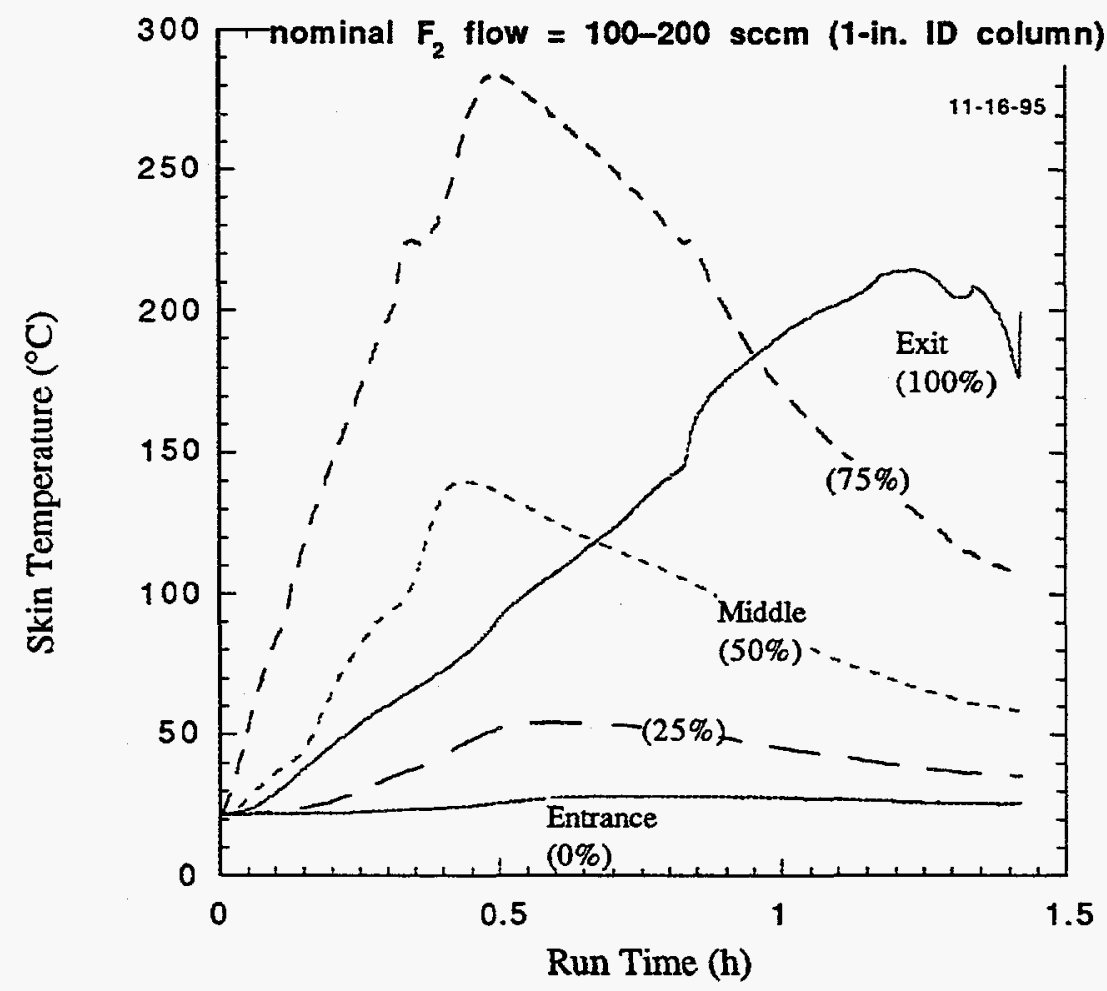

Fig. A-3. Skin temperatures for FTT-1B, 100-200 sccm fluorine, 1-in.-ID trap. 


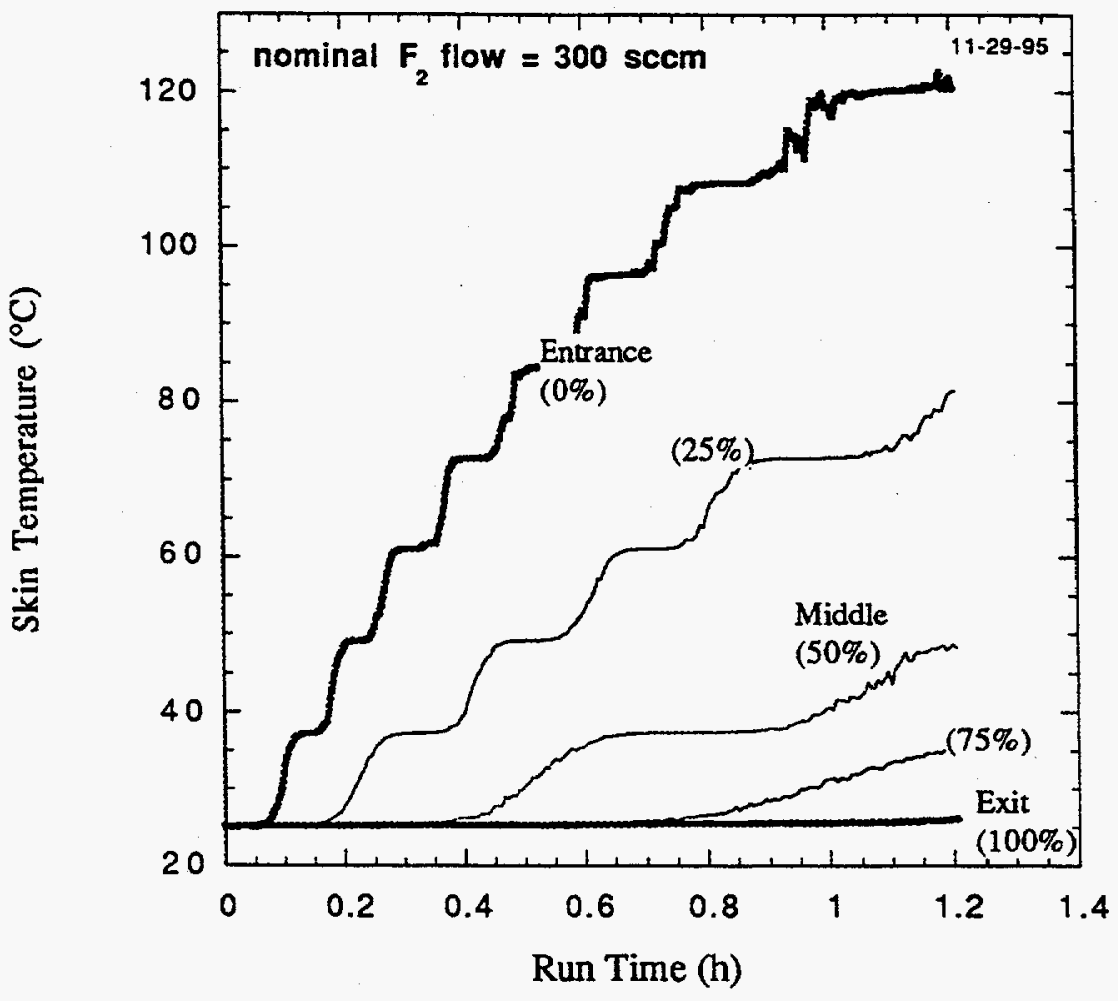

Fig. A-4. Skin temperatures for FTT-3A, $300 \mathrm{sccm}$ fluorine.

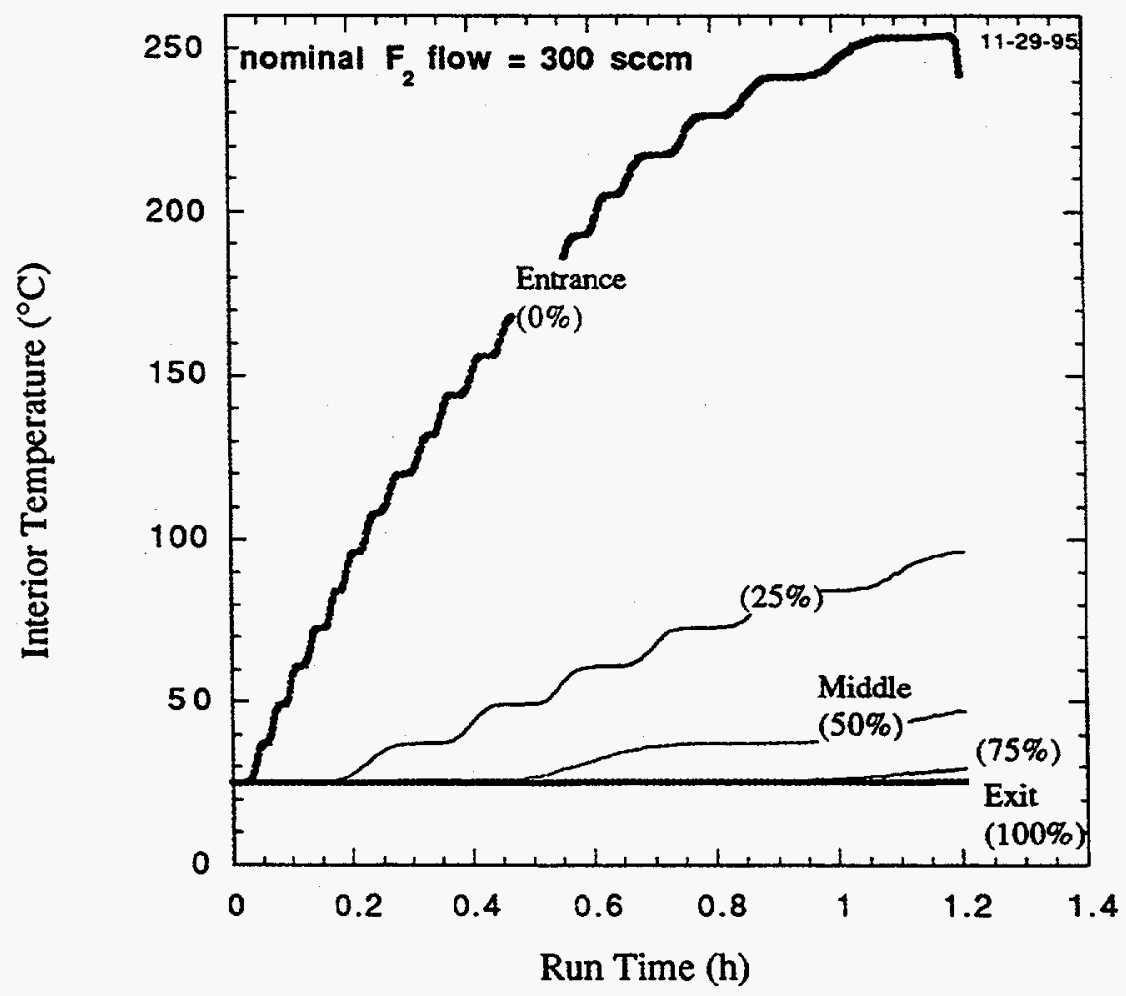

Fig. A-5. Internal temperatures for FTT-3A, $300 \mathrm{sccm}$ fluorine. 


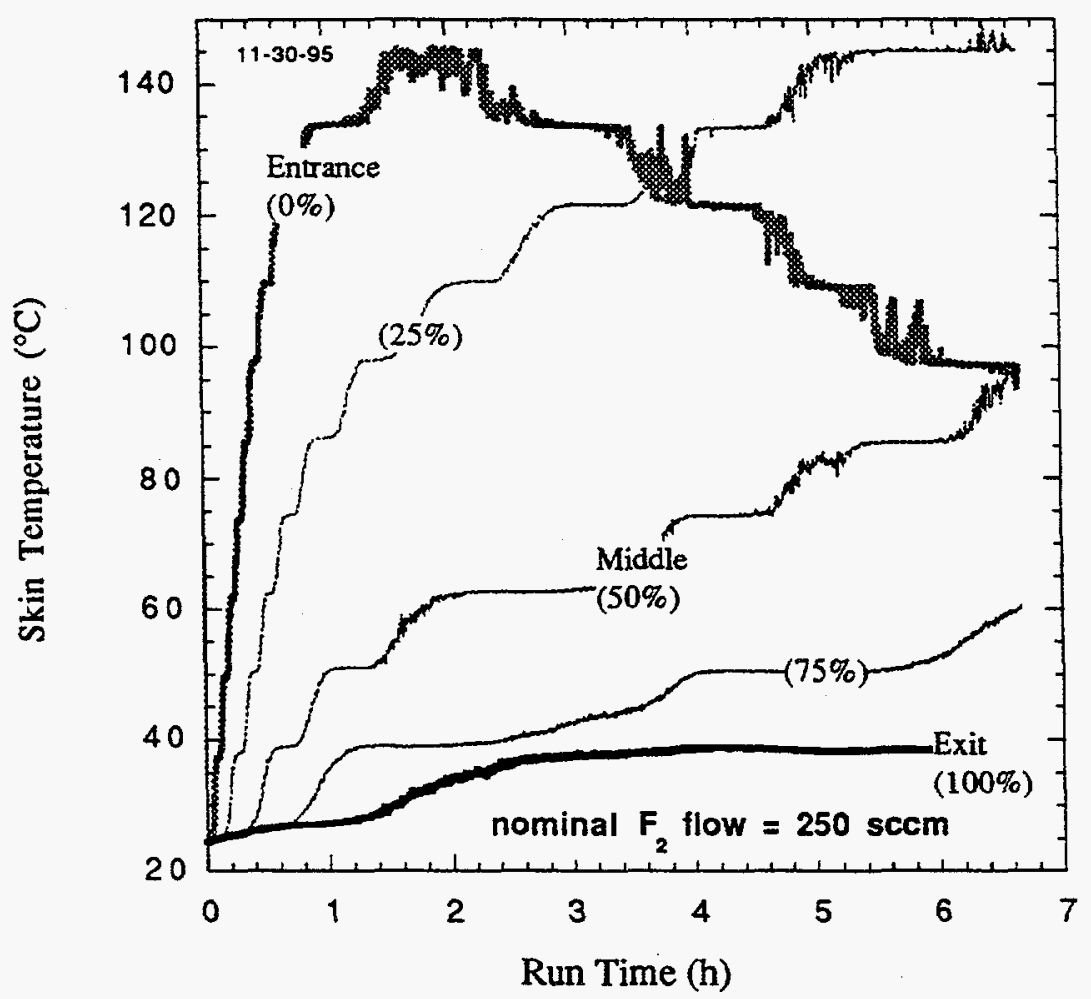

Fig. A-6. Skin temperatures for FTT-3B, $250 \mathrm{sccm}$ fluorine.

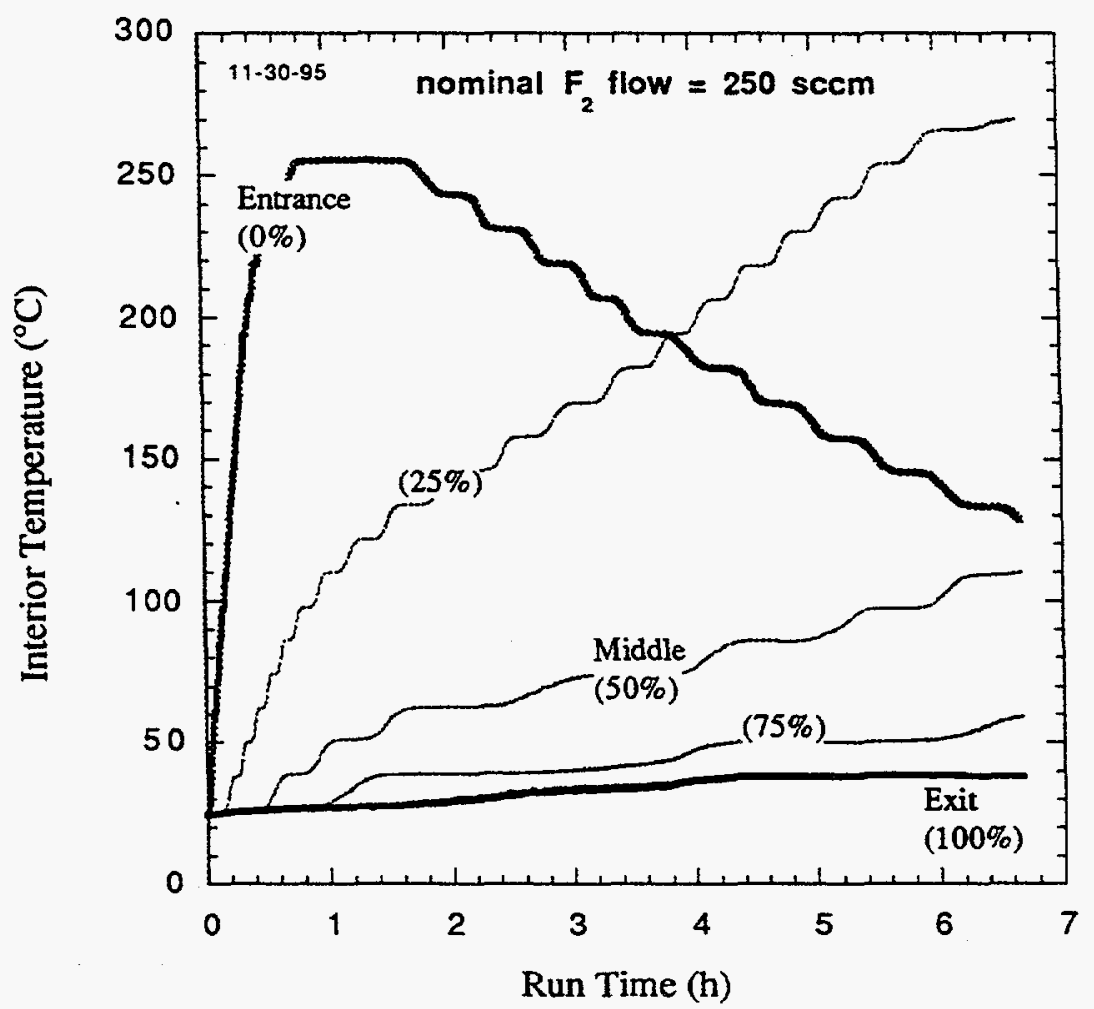

Fig. A-7. Internal temperatures for FTT-3B, $250 \mathrm{sccm}$ fluorine.

$$
A-6
$$




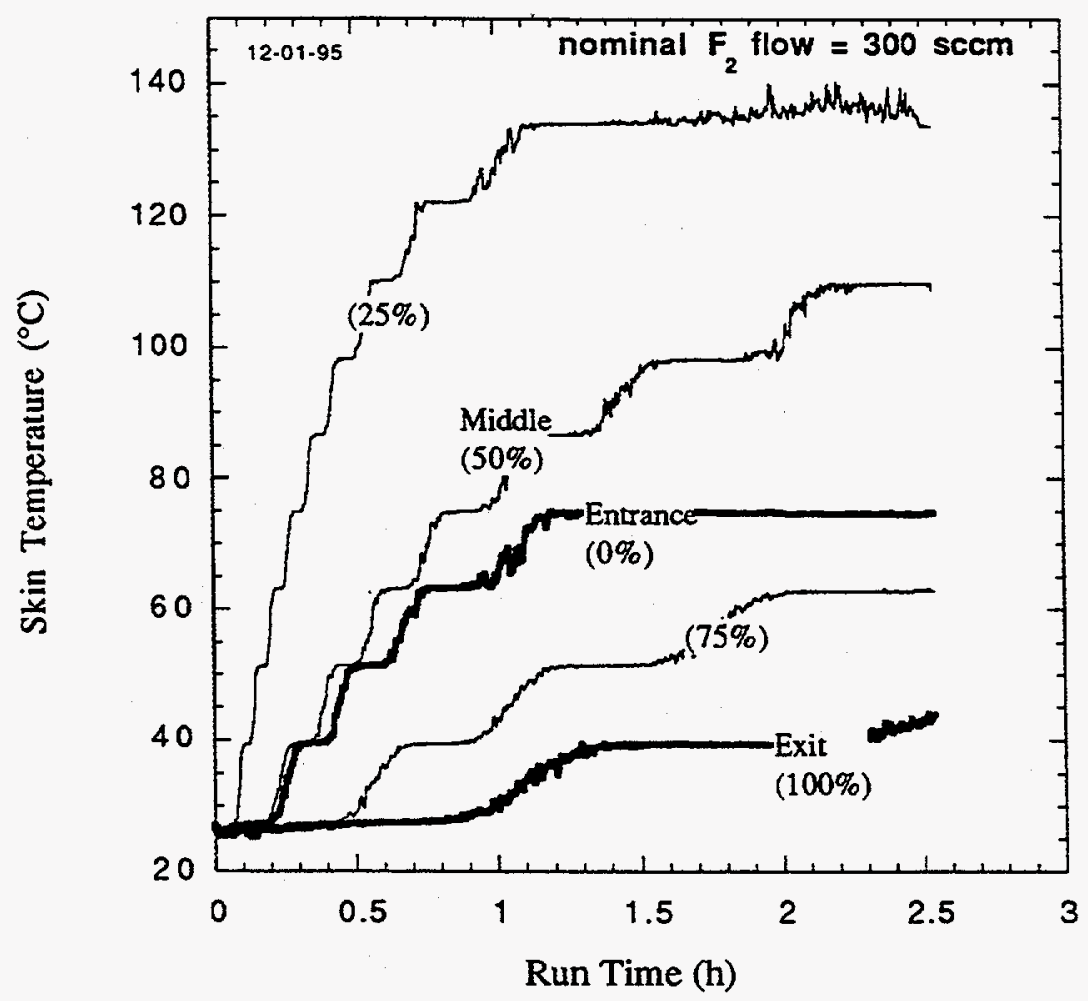

Fig. A-8. Skin temperatures for FTT-3C, $300 \mathrm{sccm}$ fluorine.

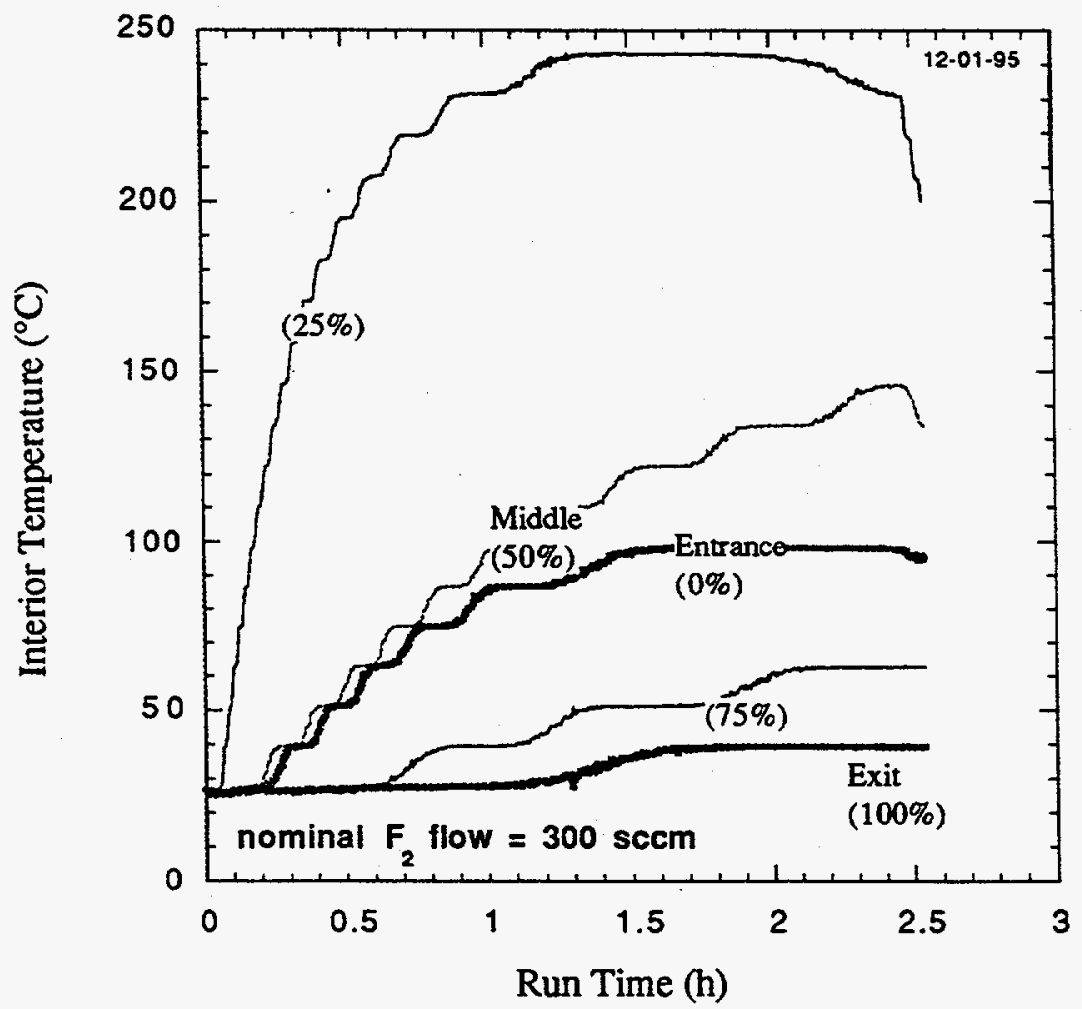

Fig. A-9. Internal temperatures for FTT-3C, $300 \mathrm{sccm}$ fluorine. 


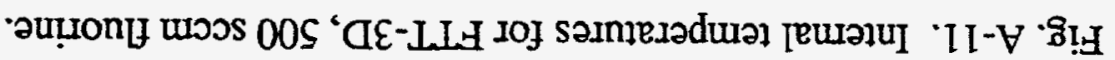

(4) วư! I uny

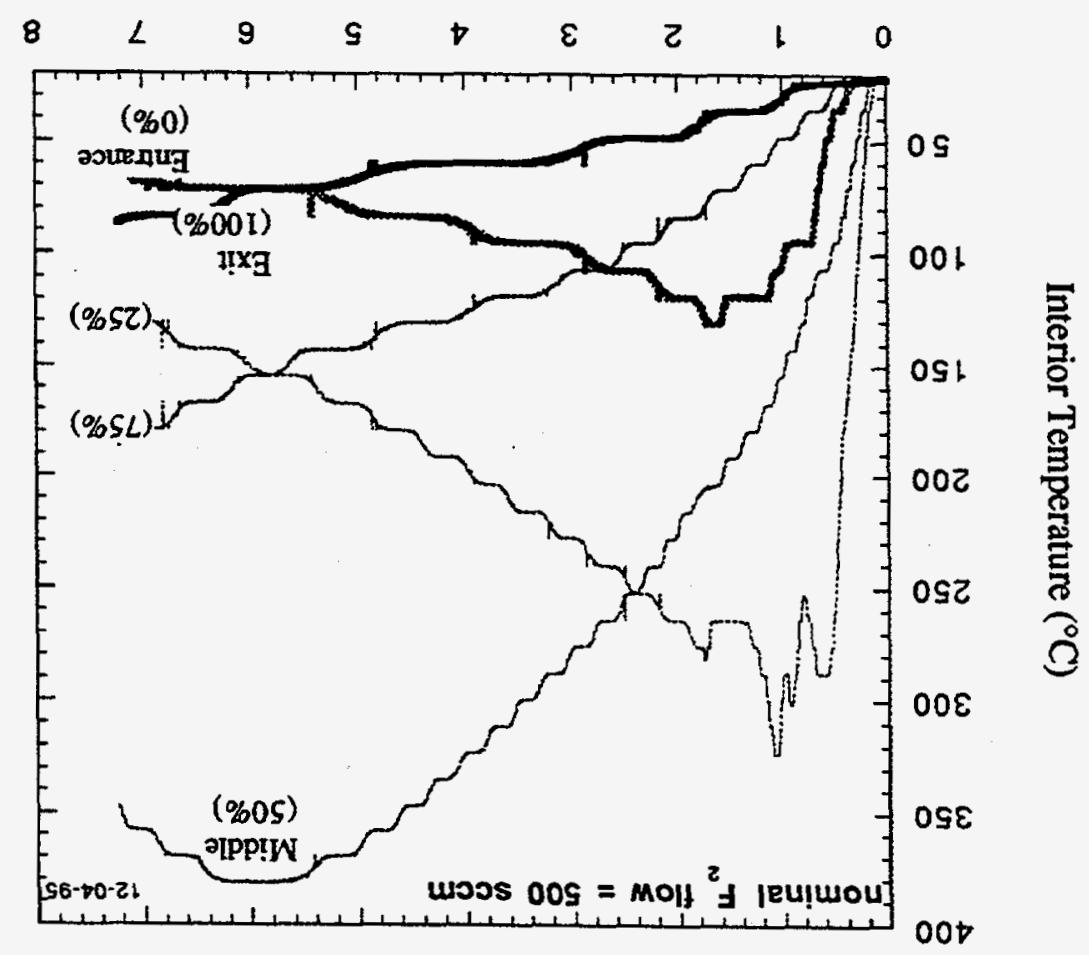

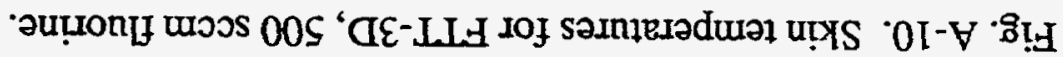

(4) วui!l uny

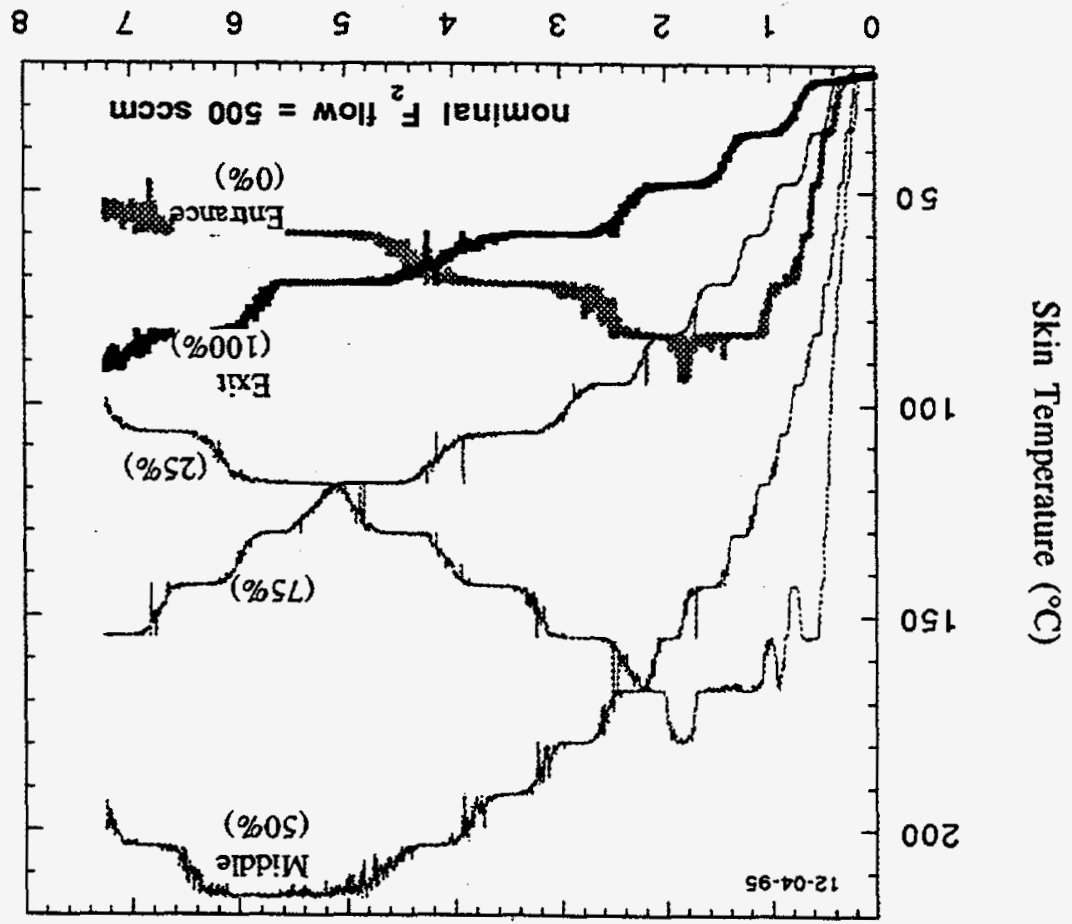




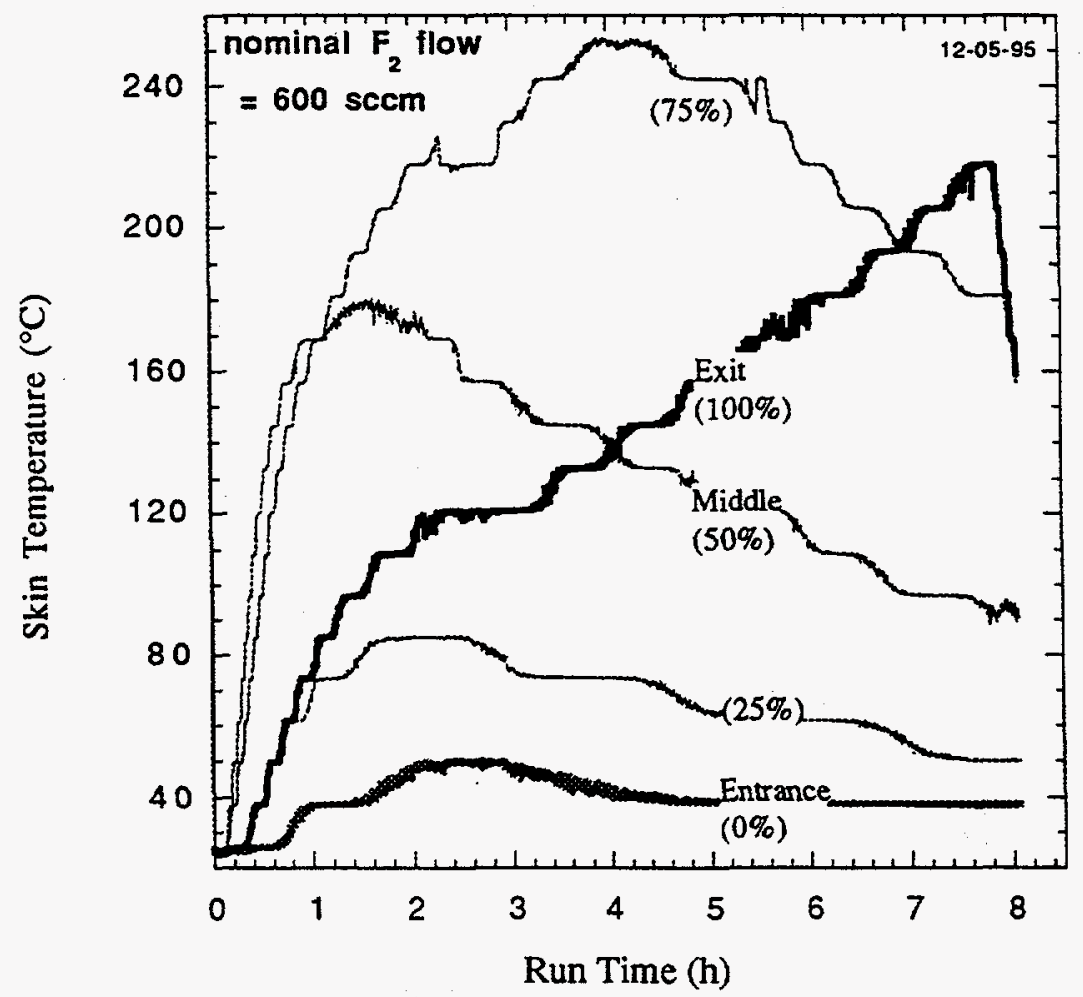

Fig. A-12. Skin temperatures for FTT-3E, $600 \mathrm{sccm}$ fluorine.

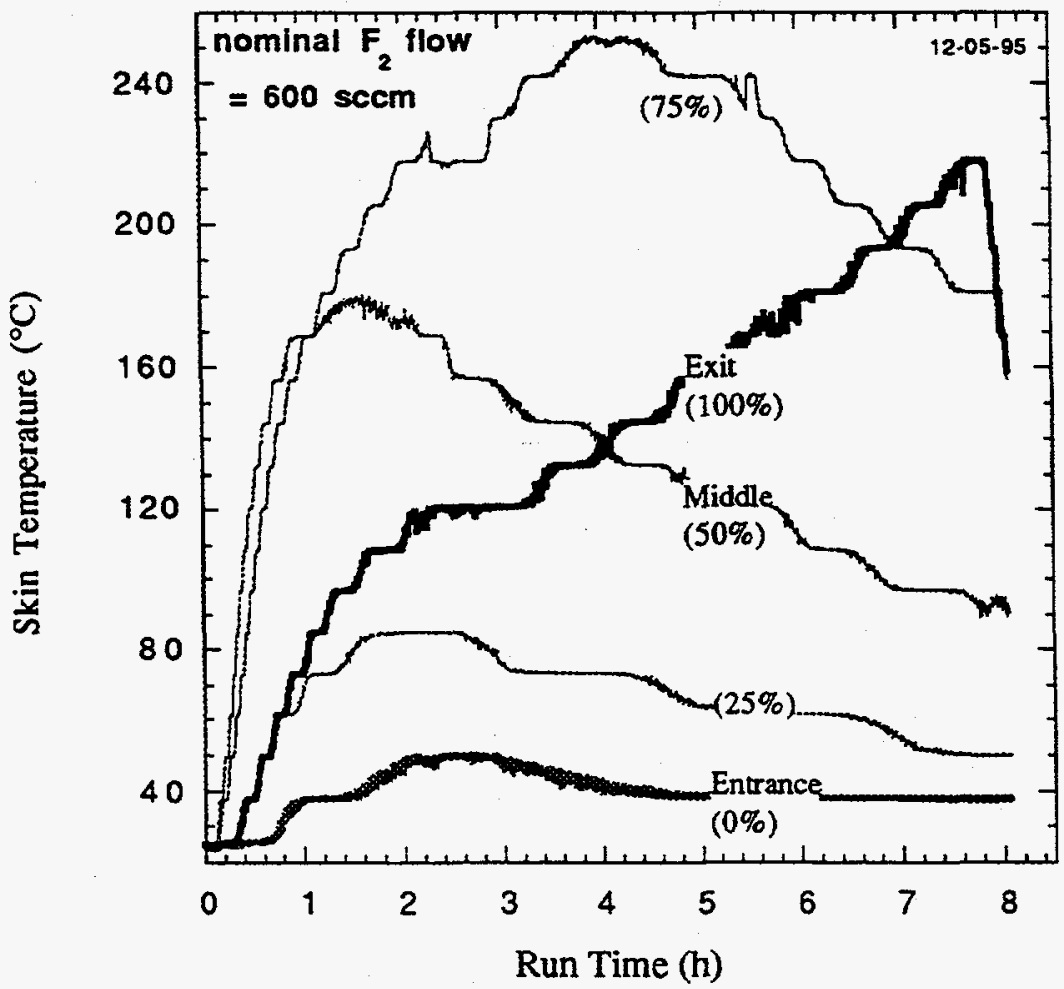

Fig. A-13. Internal temperatures for FTT-3E, $600 \mathrm{sccm}$ fluorine. 


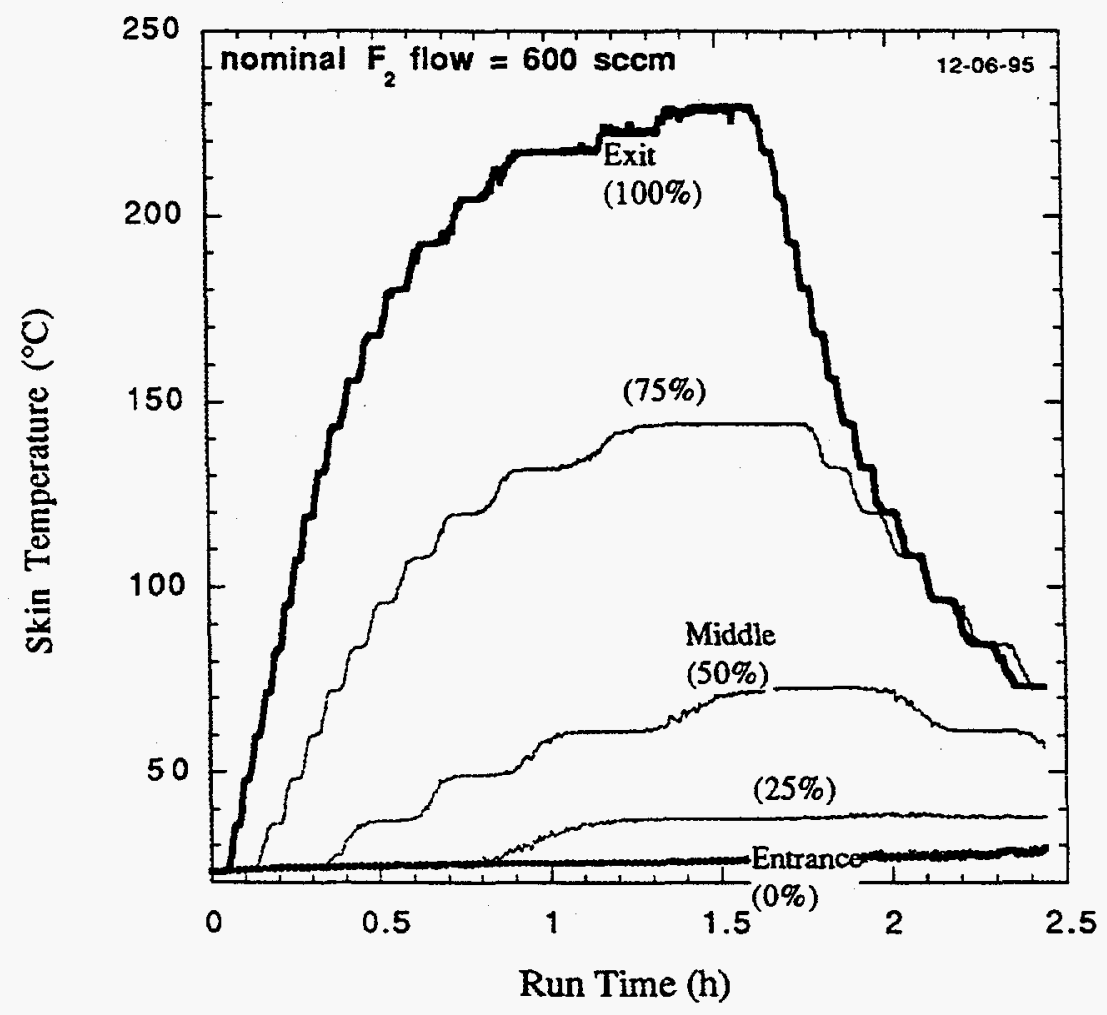

Fig. A-14. Skin temperatures for FTT-3F, $600 \mathrm{sccm}$ fluorine.

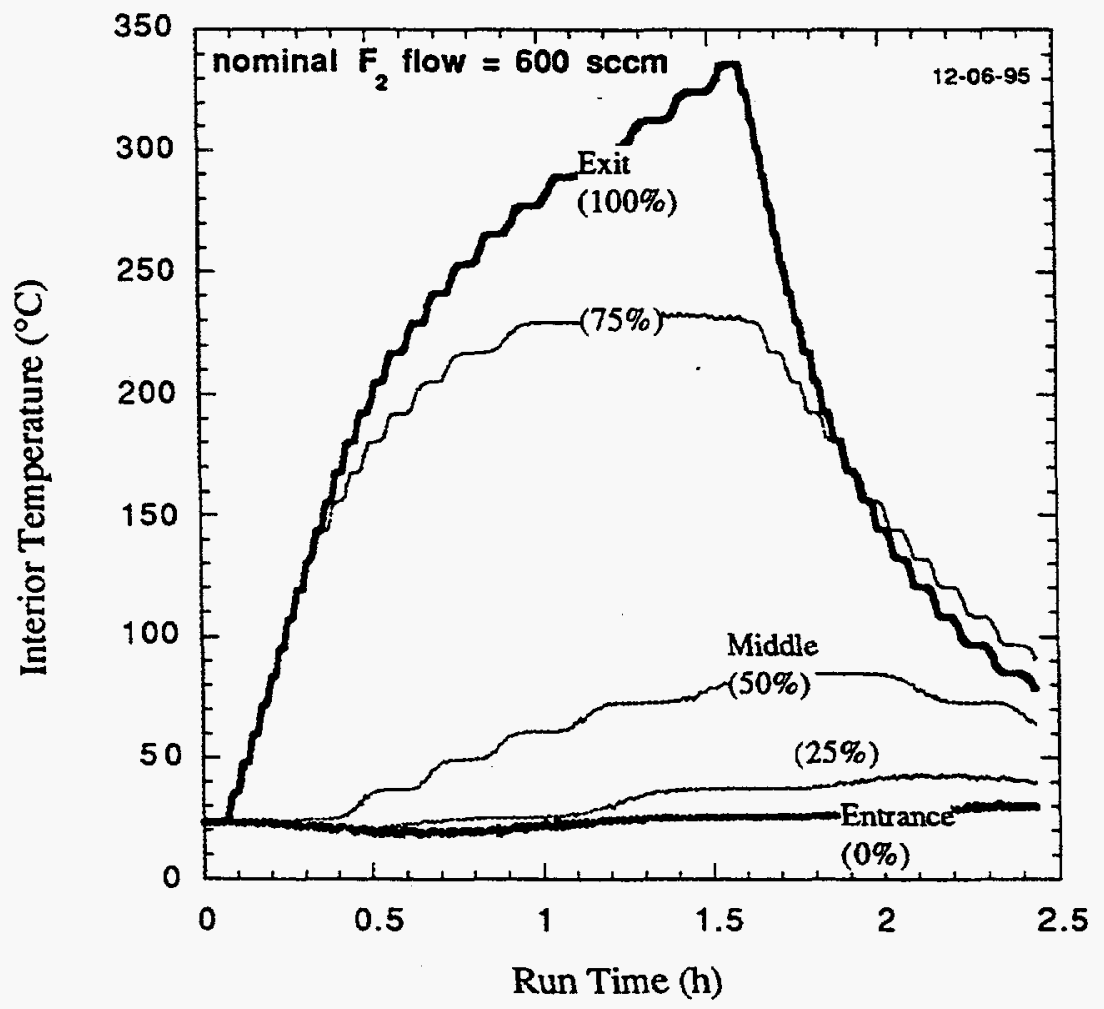

Fig. A-15. Internal temperatures for FTT-3F, $600 \mathrm{sccm}$ fluorine. 


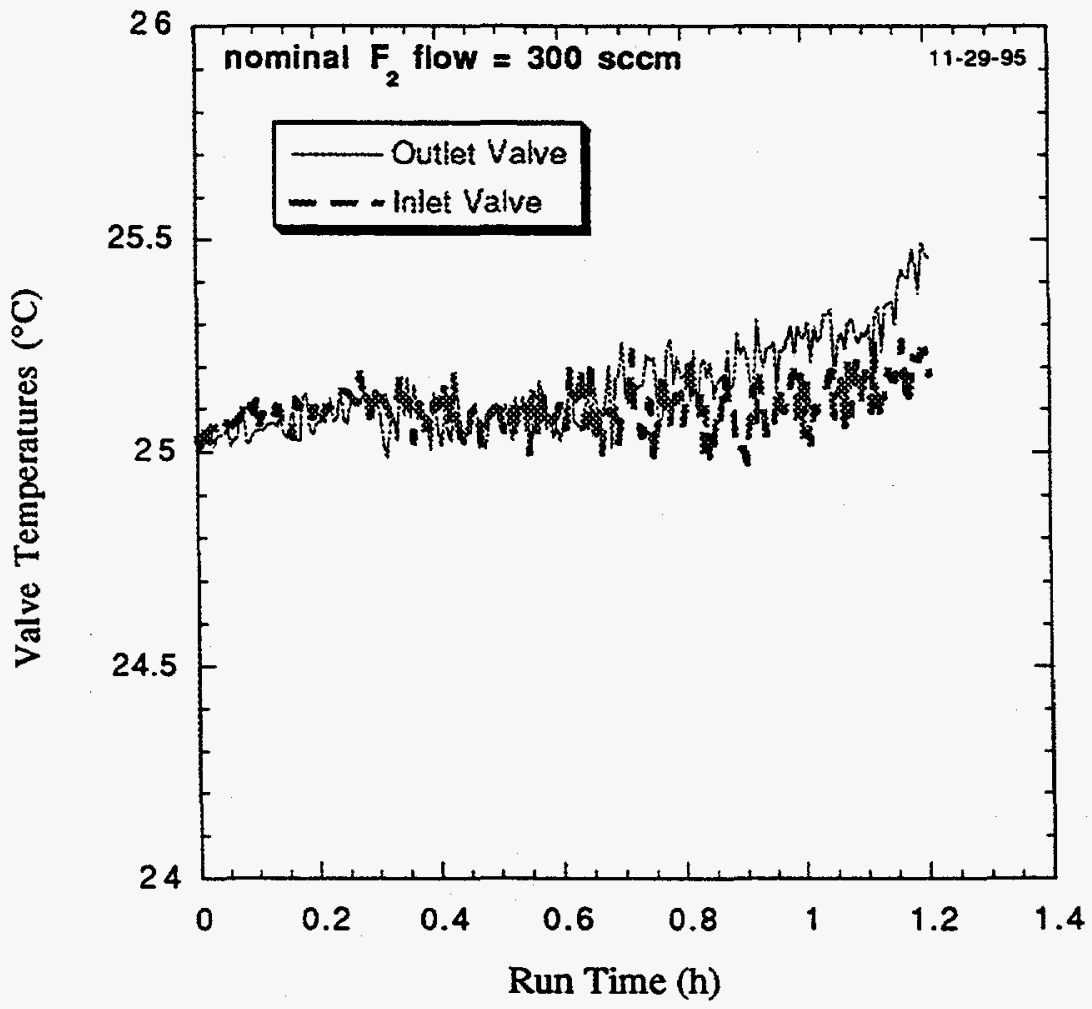

Fig. A-16. Valve temperatures for FTT-3A, $300 \mathrm{sccm}$ fluorine.

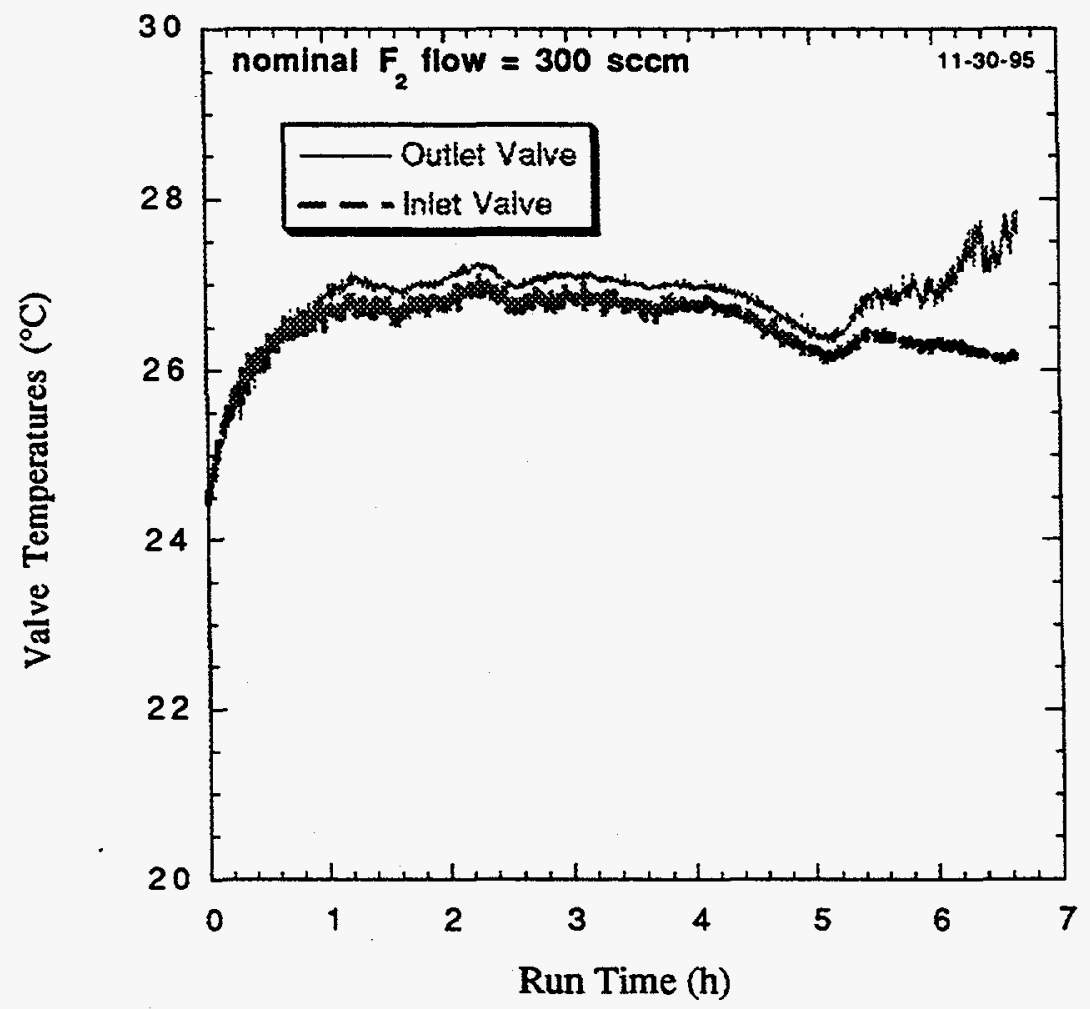

Fig. A-17. Valve temperatures for FTT-3B, $250 \mathrm{sccm}$ fluorine. 


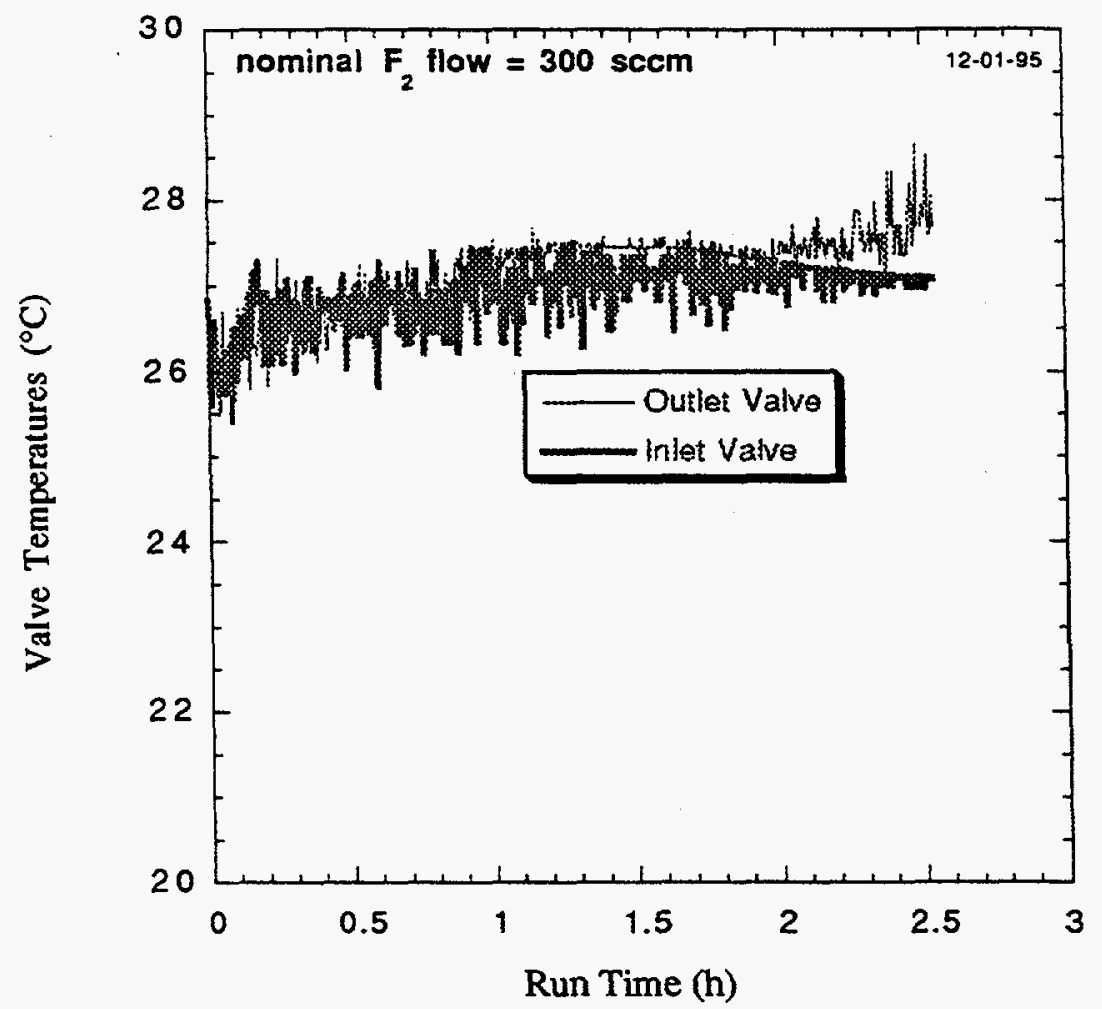

Fig. A-18. Valve temperatures for FTT-3C, $300 \mathrm{sccm}$ fluorine.

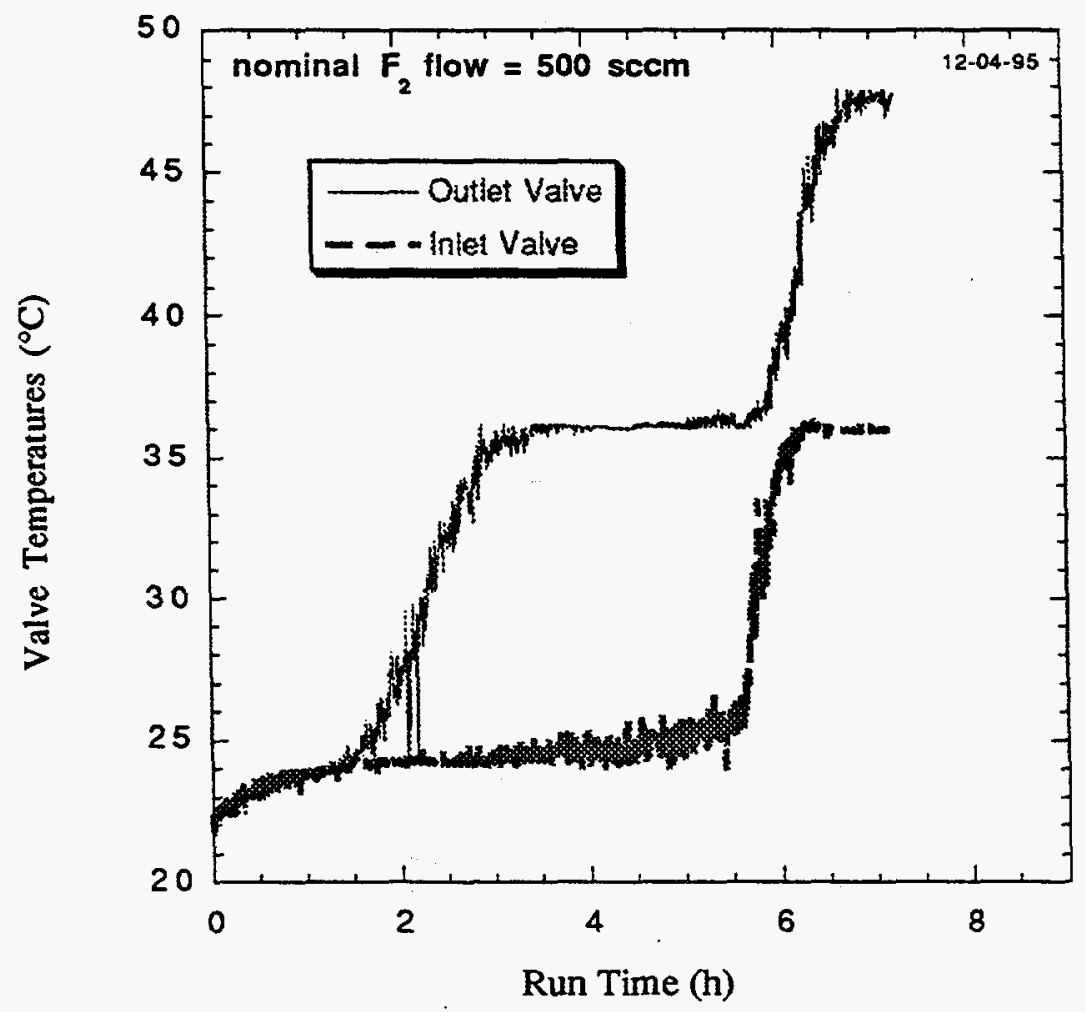

Fig. A-19. Valve temperatures for FTT-3D, 500 sccm fluorine. 


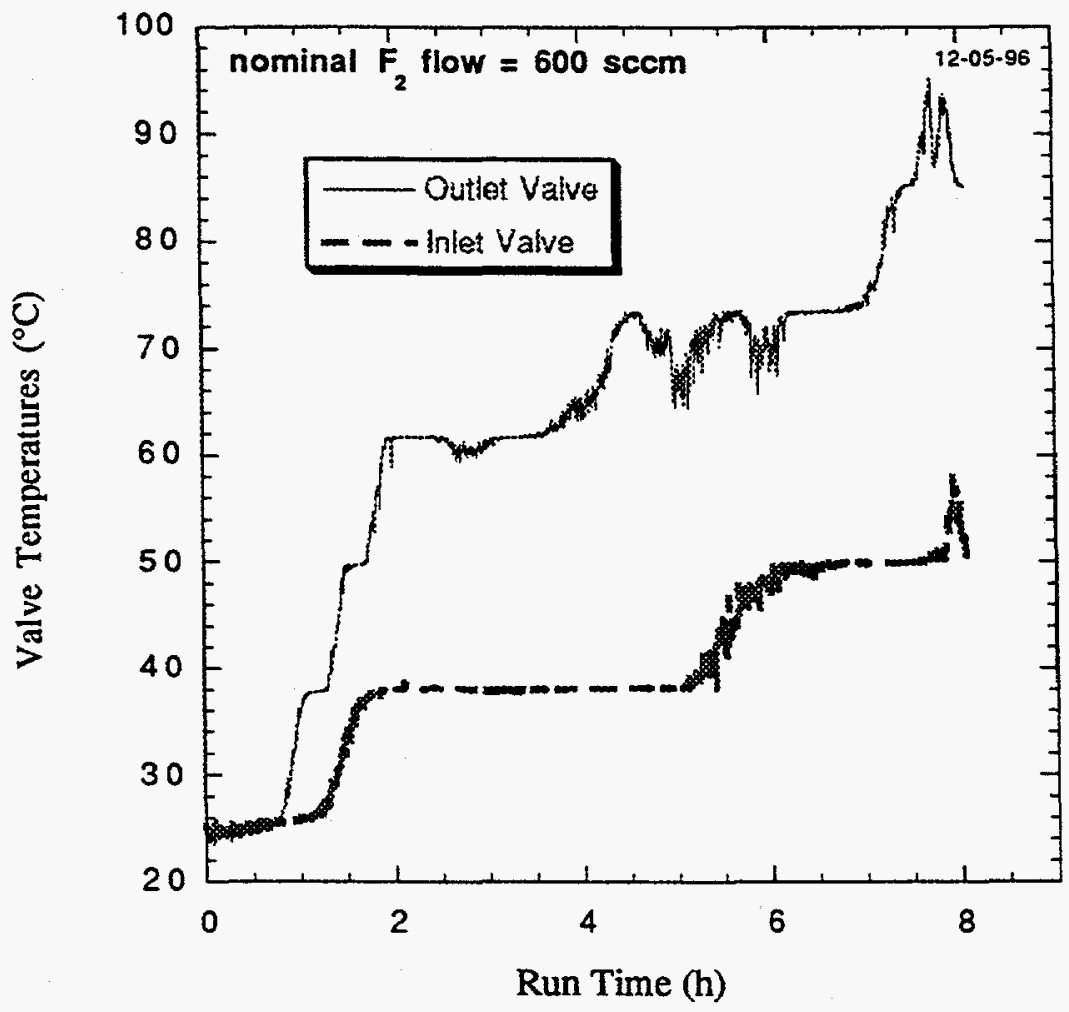

Fig. A-20. Valve temperatures for FTT-3E, $600 \mathrm{sccm}$ fluorine.

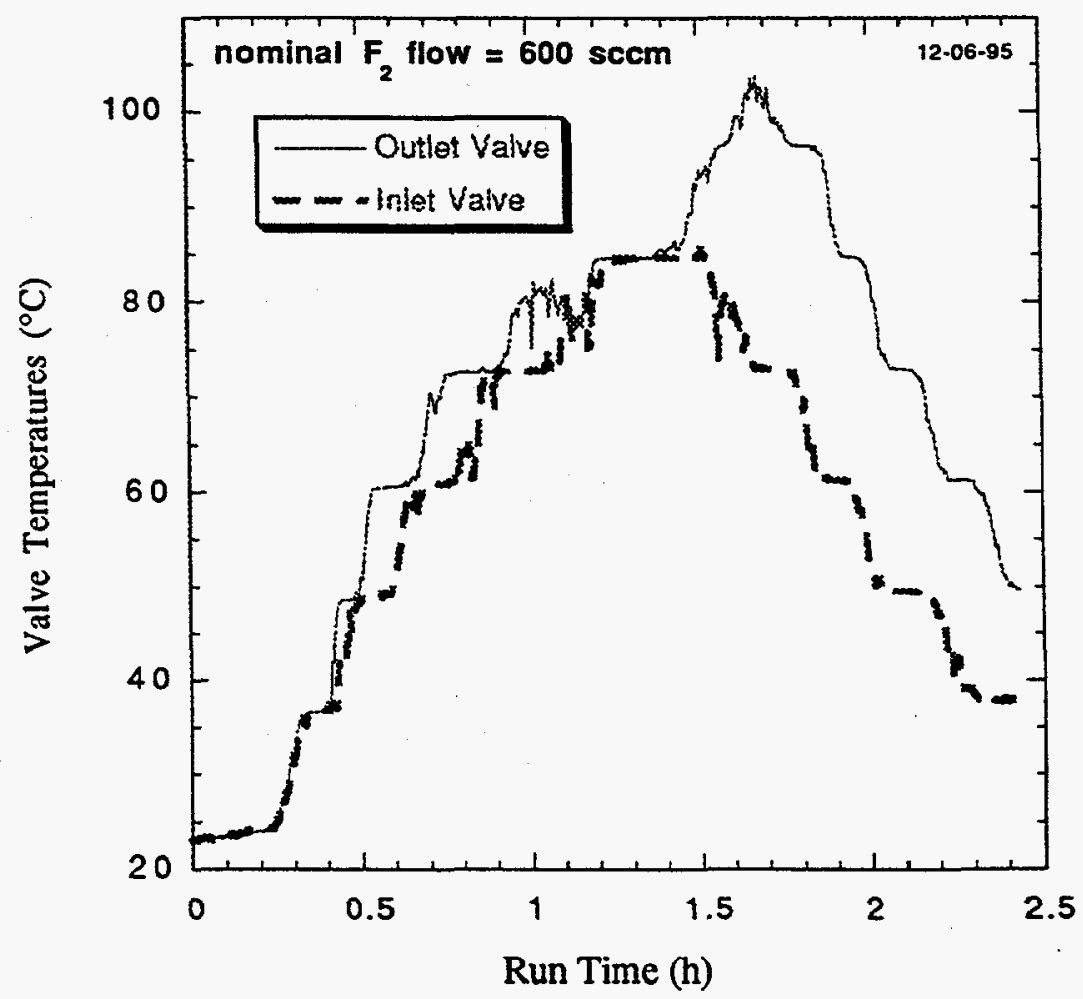

Fig. A-21. Valve temperatures for FTT-3F, $600 \mathrm{sccm}$ fluorine. 


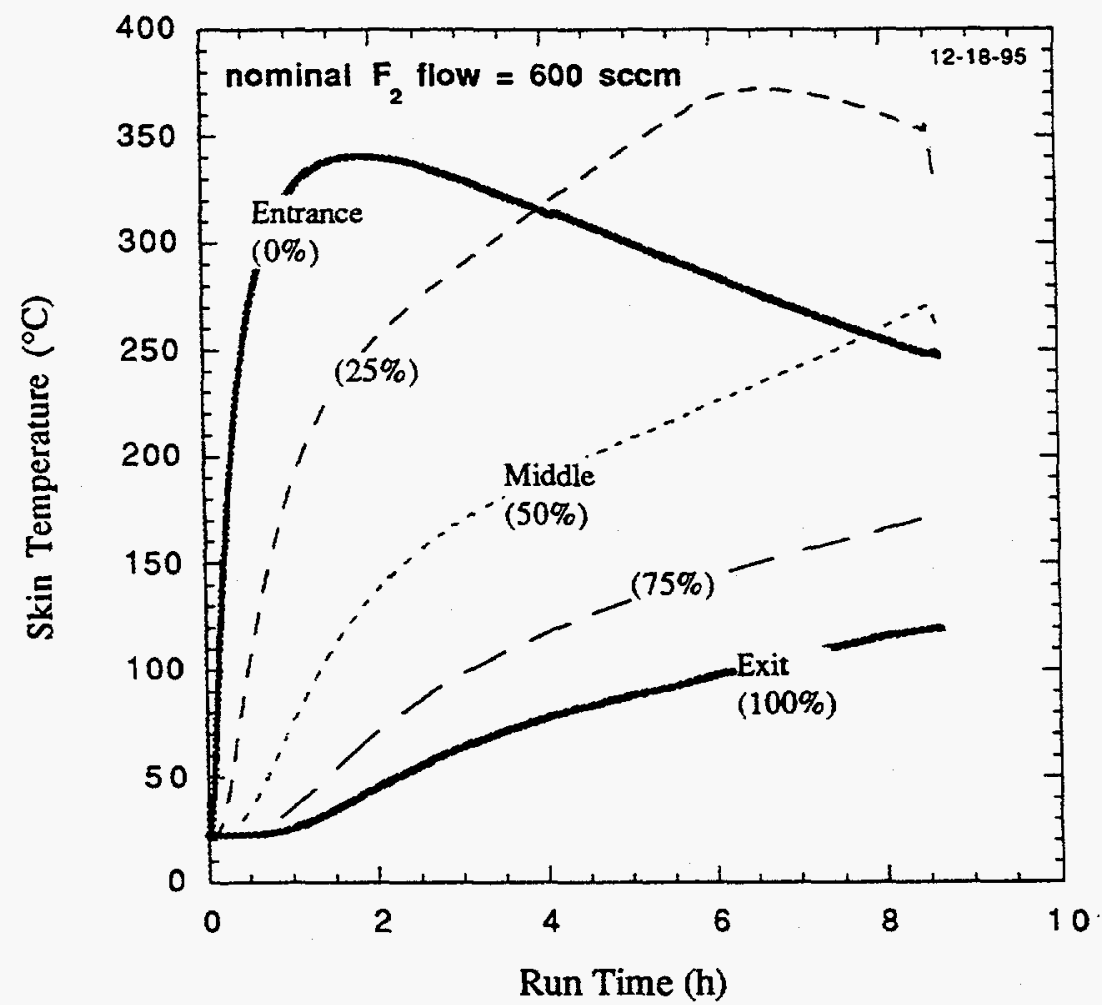

Fig. A-22. Skin temperatures for FTT-4A, 600 sccm fluorine.

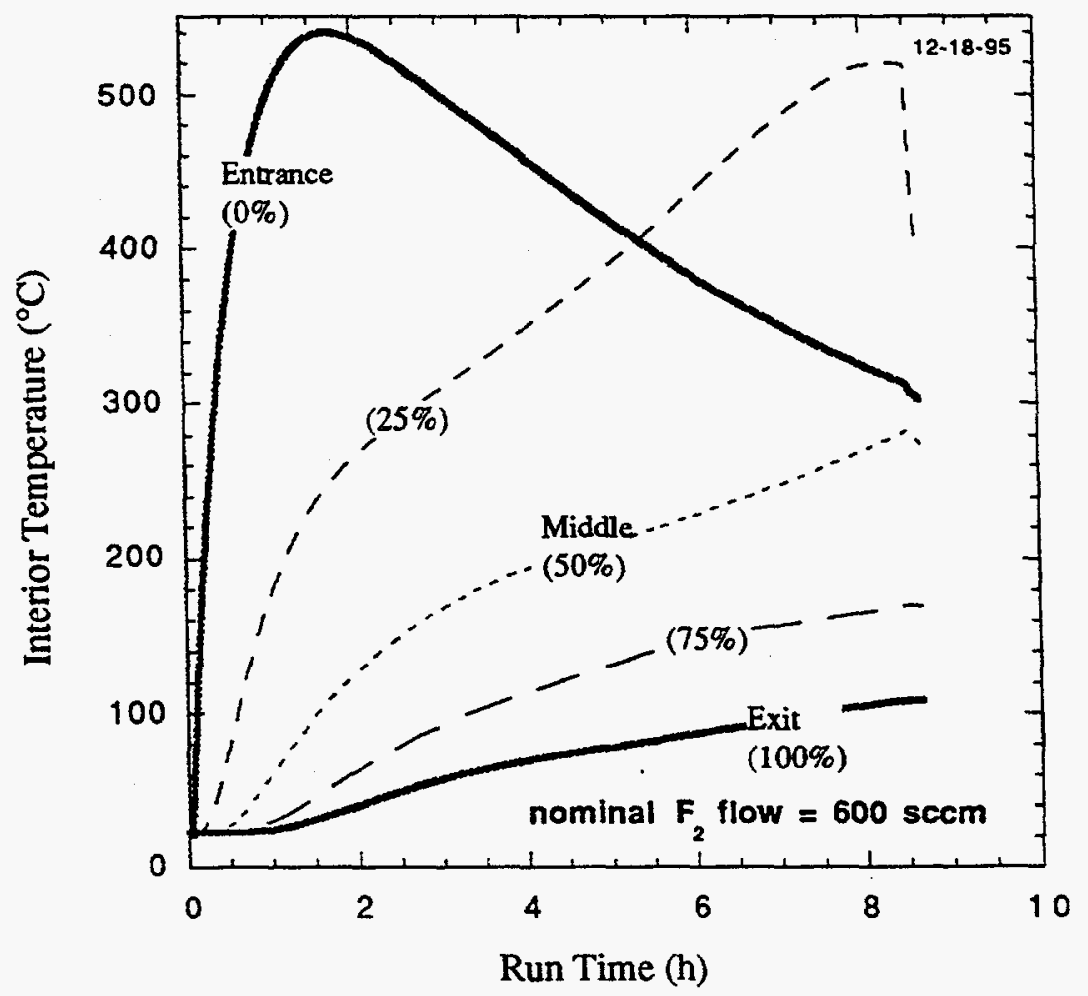

Fig. A-23. Internal temperatures for FTT-4A, $600 \mathrm{sccm}$ fluorine. 


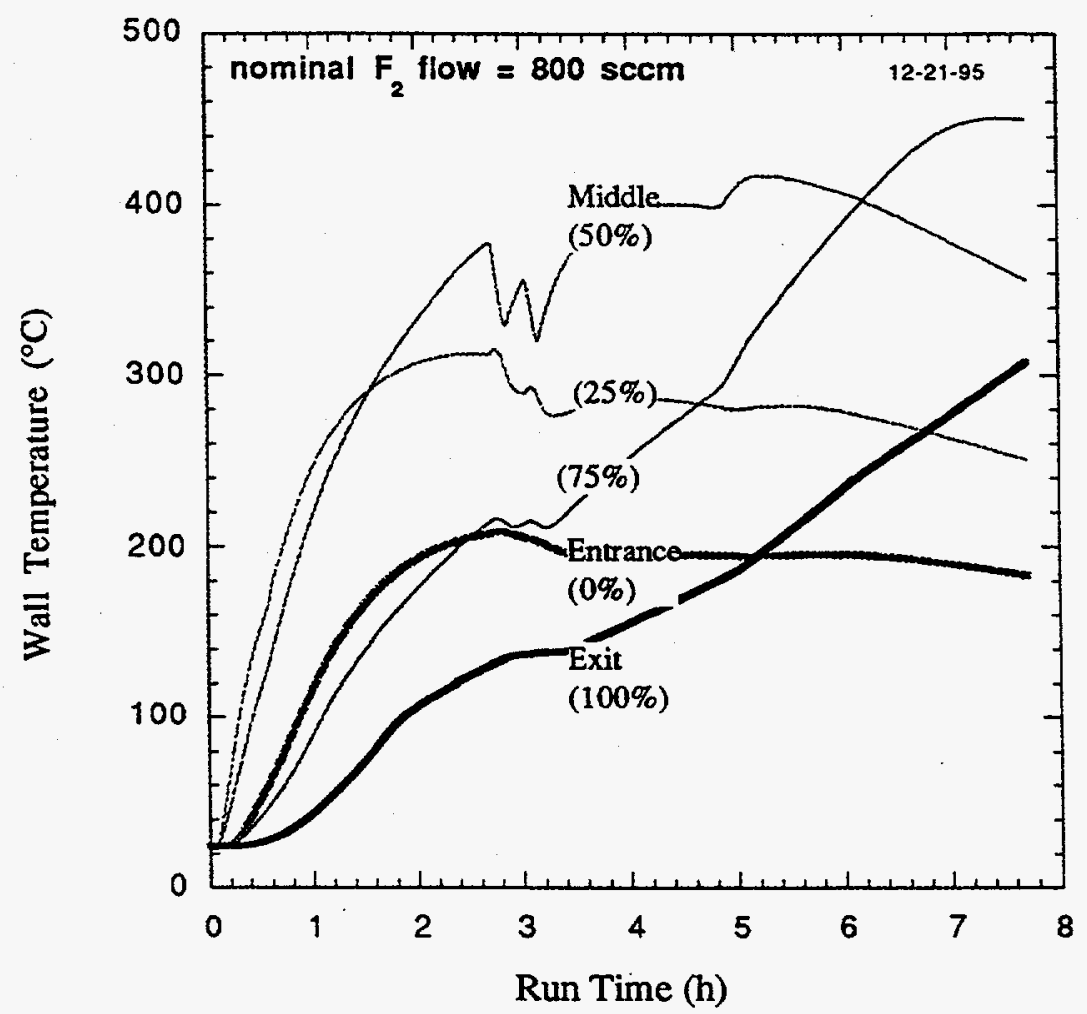

Fig. A-24. Skin temperatures for FTT-4B, $800 \mathrm{sccm}$ fluorine.

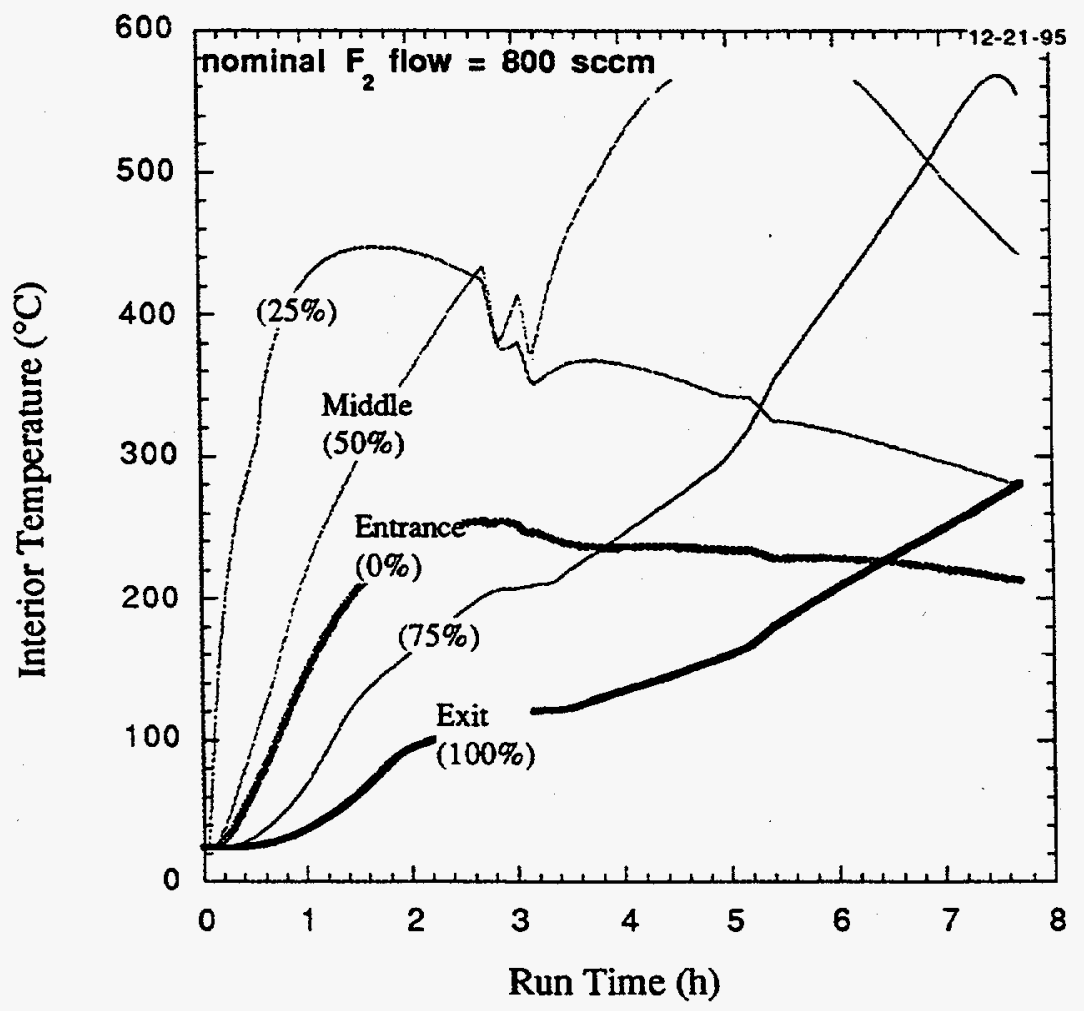

Fig. A-25. Internal temperatures for FTT-4B, $800 \mathrm{sccm}$ fluorine. 


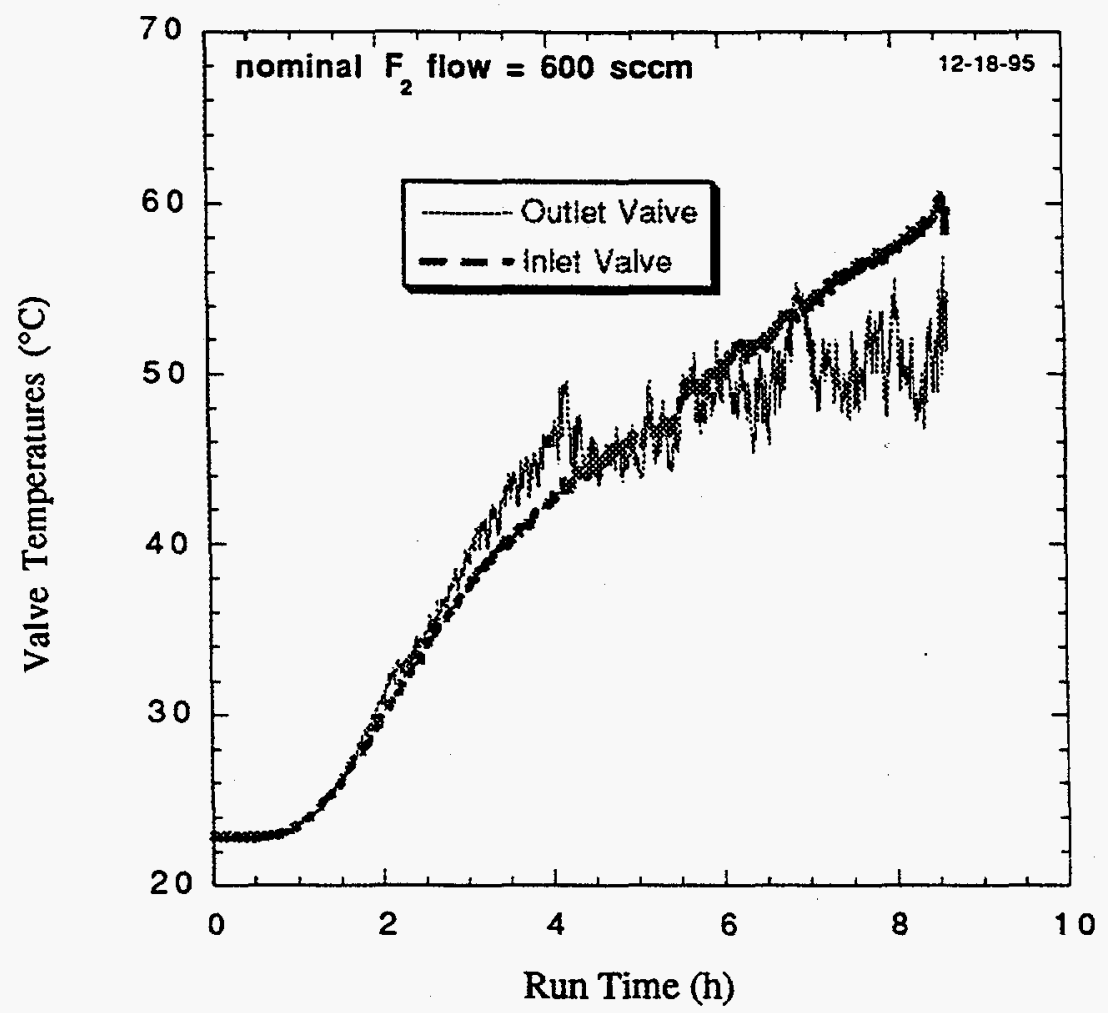

Fig. 26. Valve temperatures for FTT-4A, $600 \mathrm{sccm}$ fluorine.

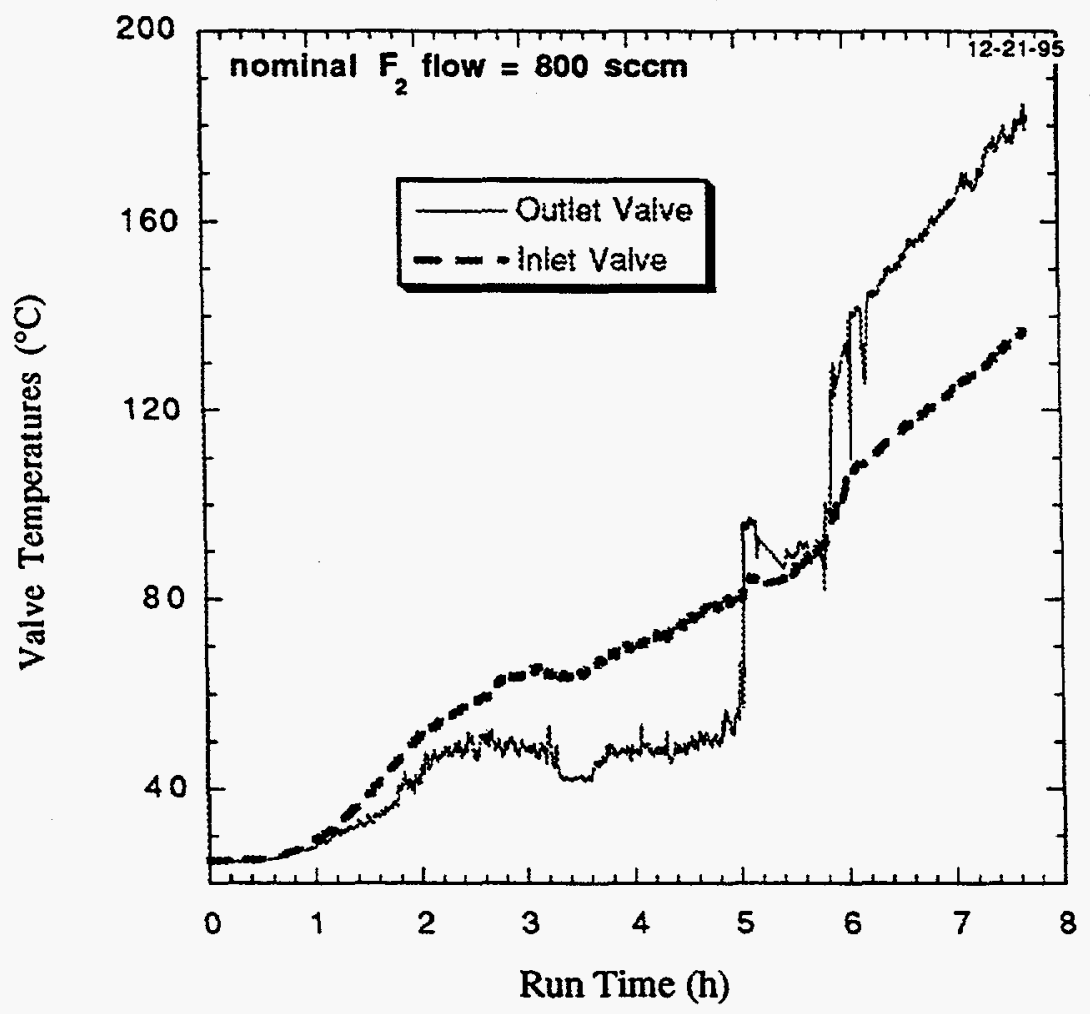

Fig. A-27. Valve temperatures for FTT-4B, $800 \mathrm{sccm}$ fluorine. 


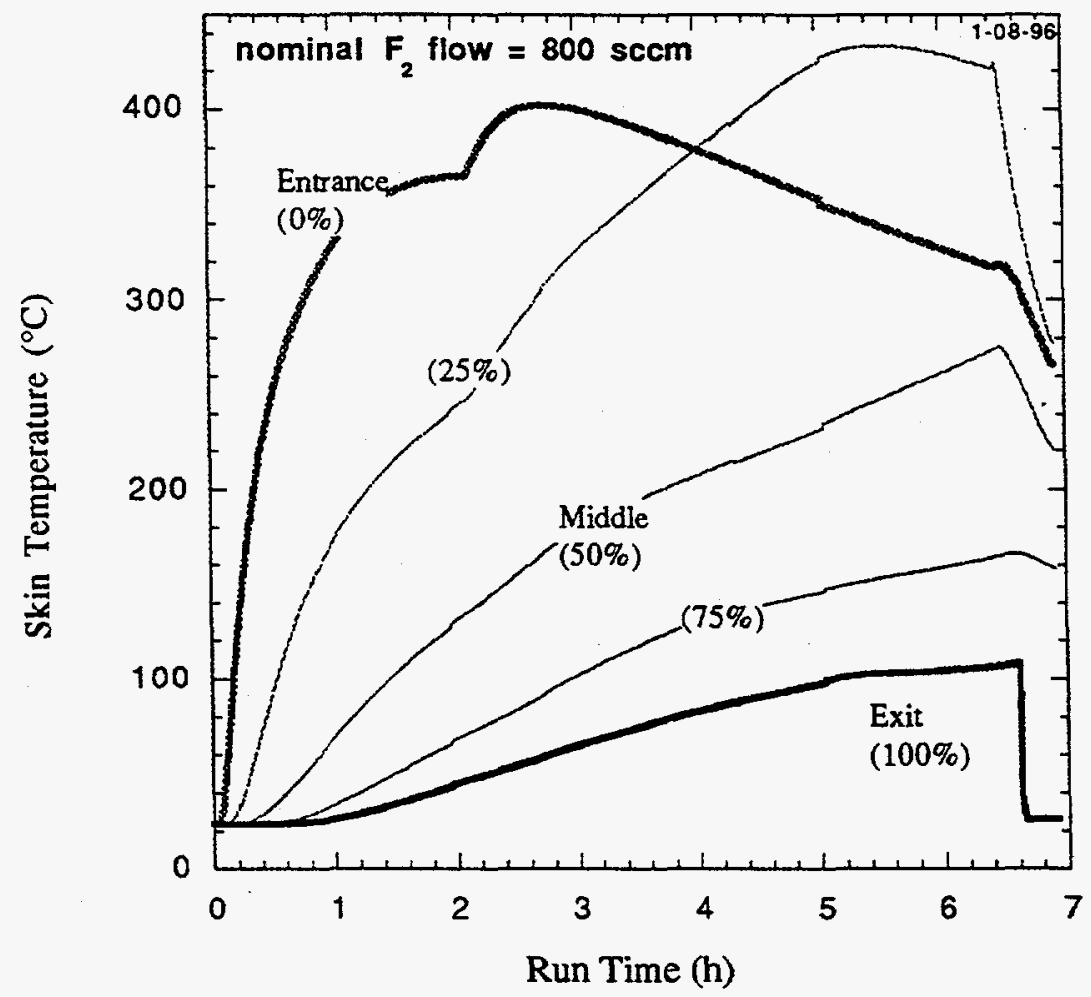

Fig. A-28. Skin temperatures for FTT-5A, $800 \mathrm{sccm}$ fluorine.

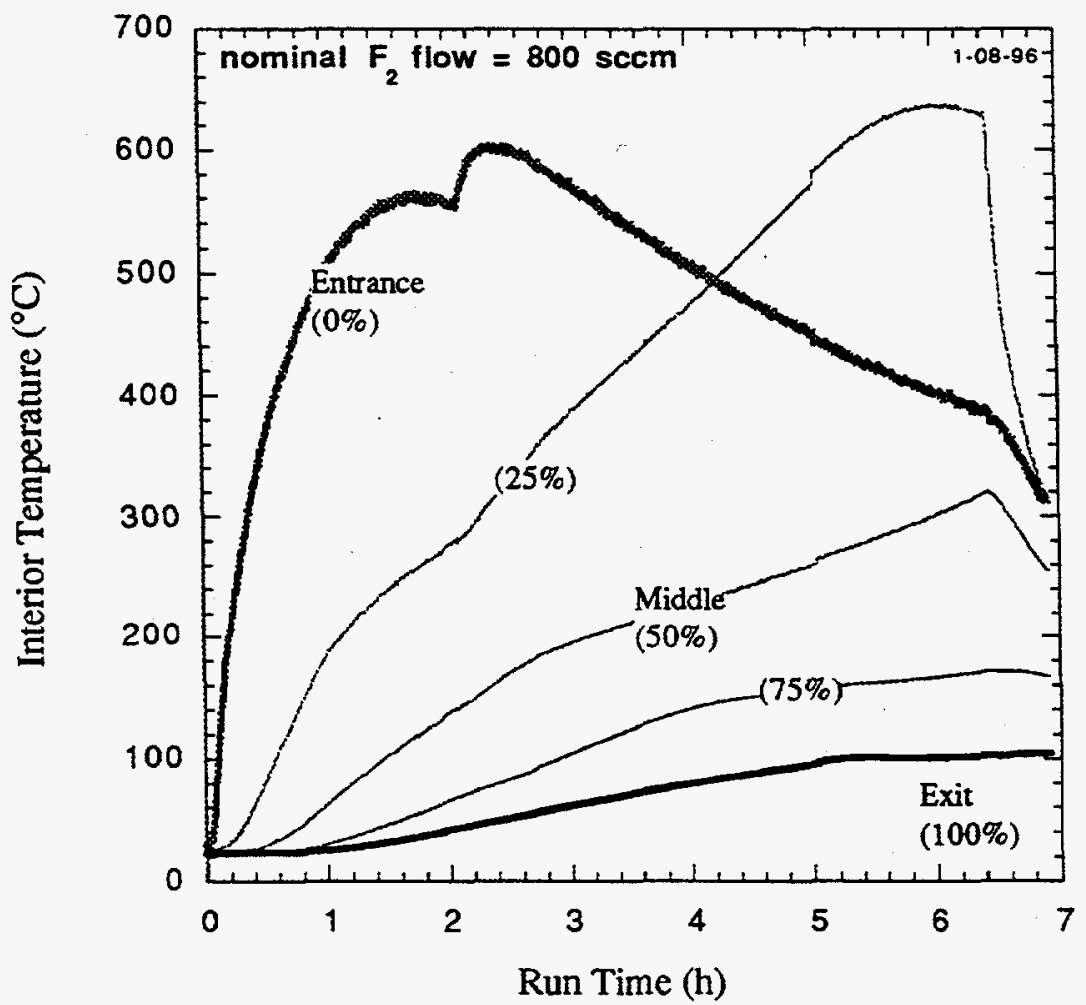

Fig. A-29. Internal temperatures for FTT-5A, $800 \mathrm{sccm}$ fluorine. 


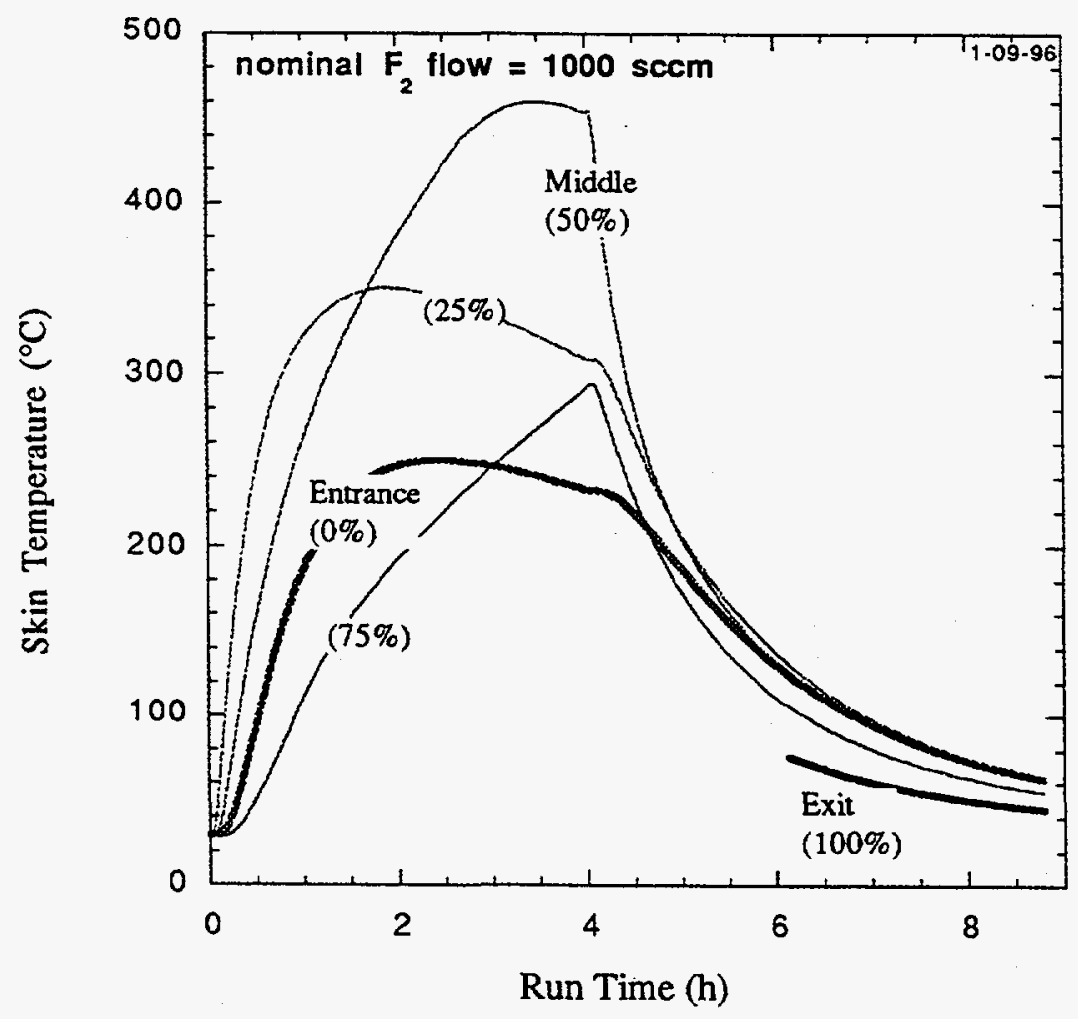

Fig. A-30. Skin temperatures for FTT-5B, $1000 \mathrm{sccm}$ fluorine.

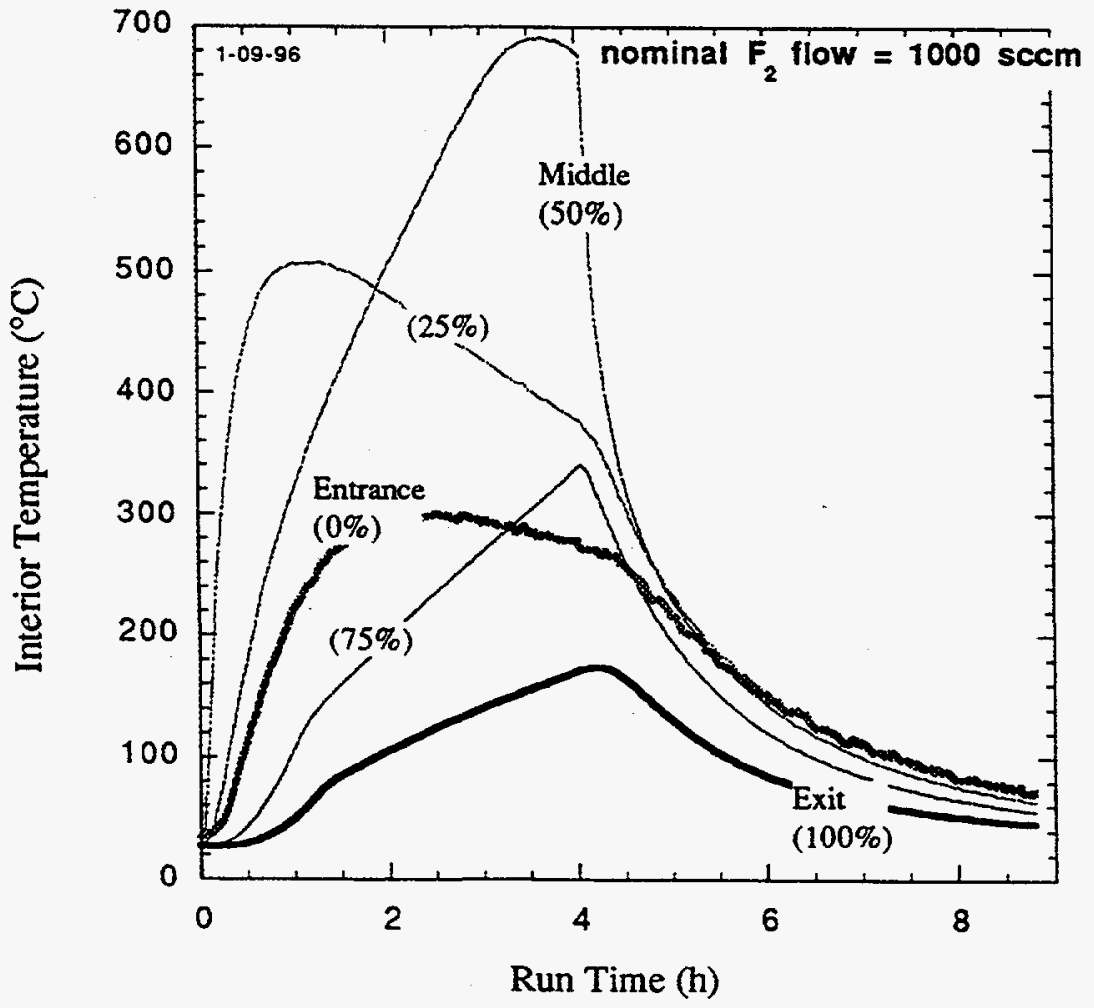

Fig. A-31. Internal temperatures for FTT-5B, $1000 \mathrm{sccm}$ fluorine. 


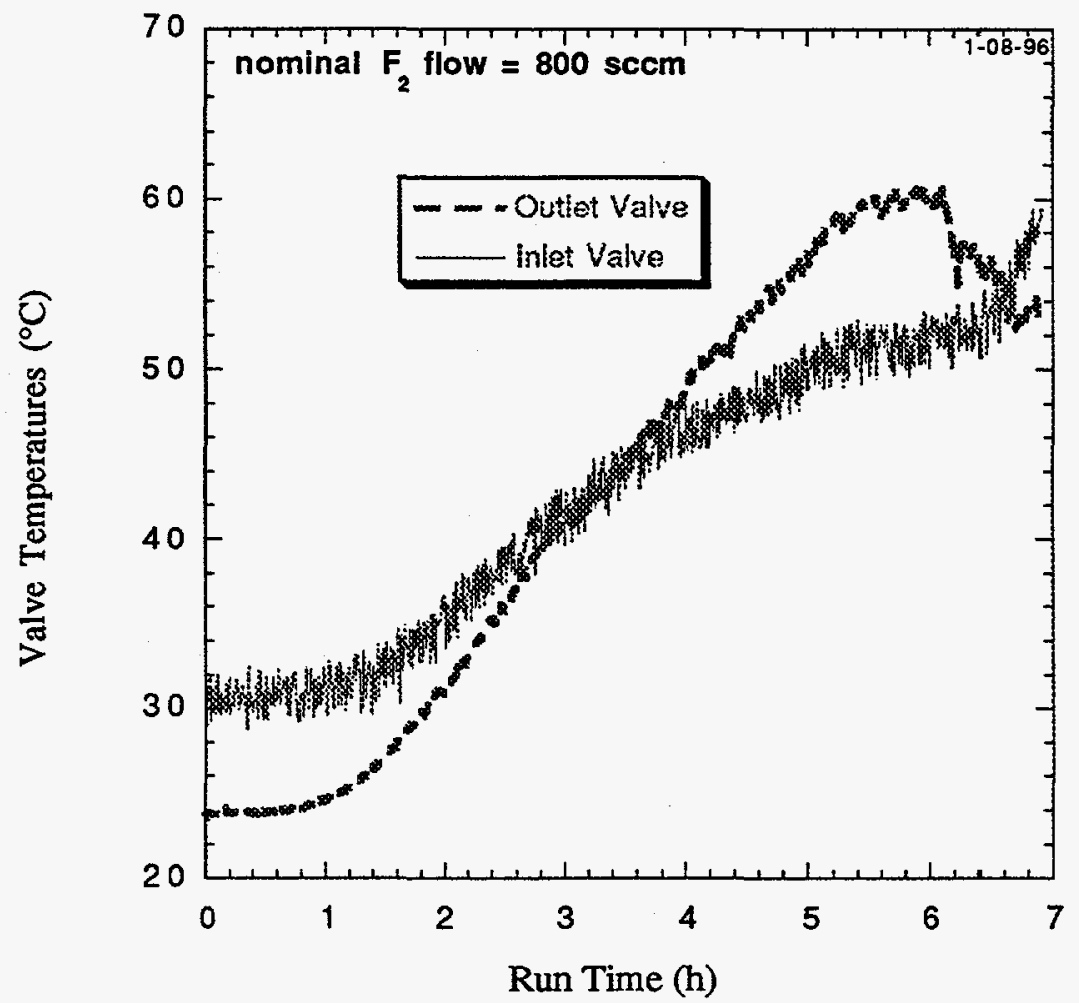

Fig. A-32. Valve temperatures for FTT-5A, $800 \mathrm{sccm}$ fluorine.

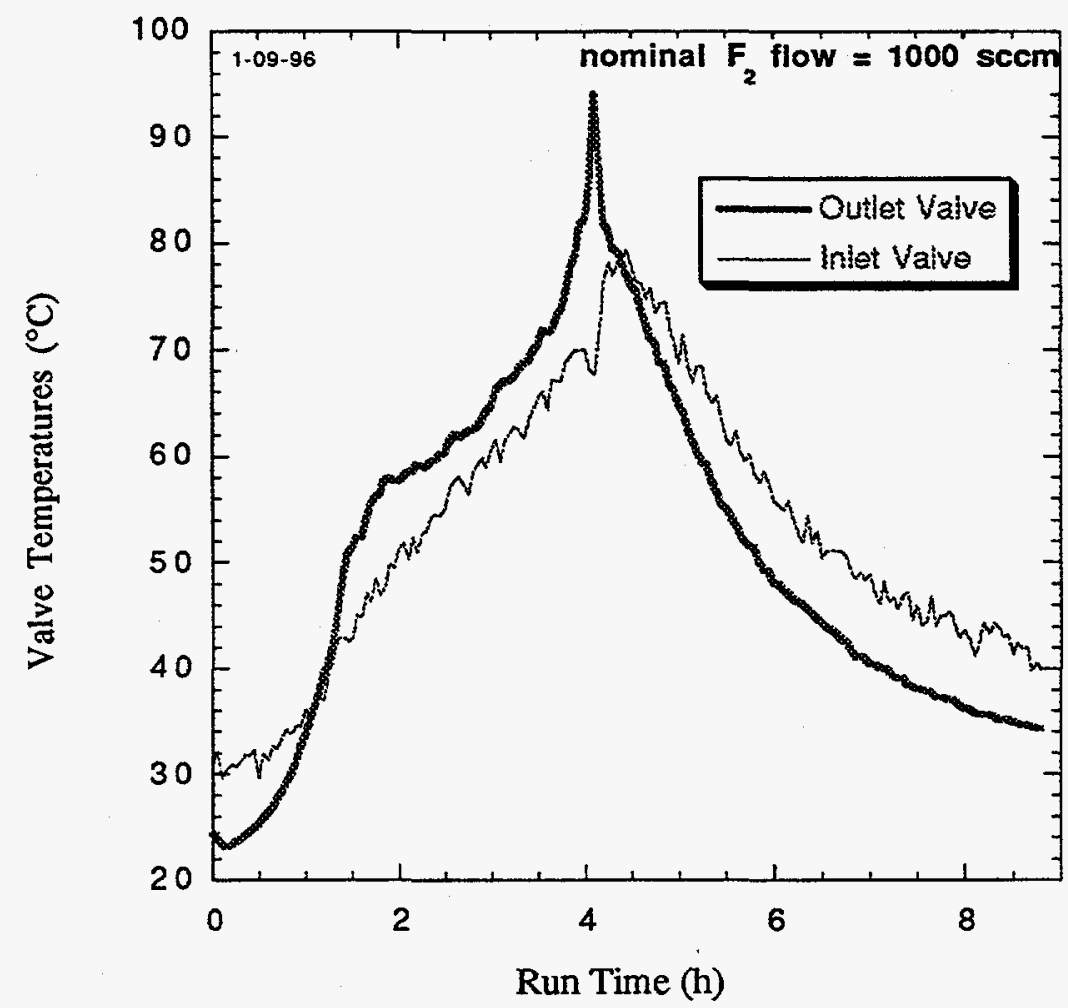

Fig. A-33. Valve temperatures for FTT-5A, $1000 \mathrm{sccm}$ fluorine. 


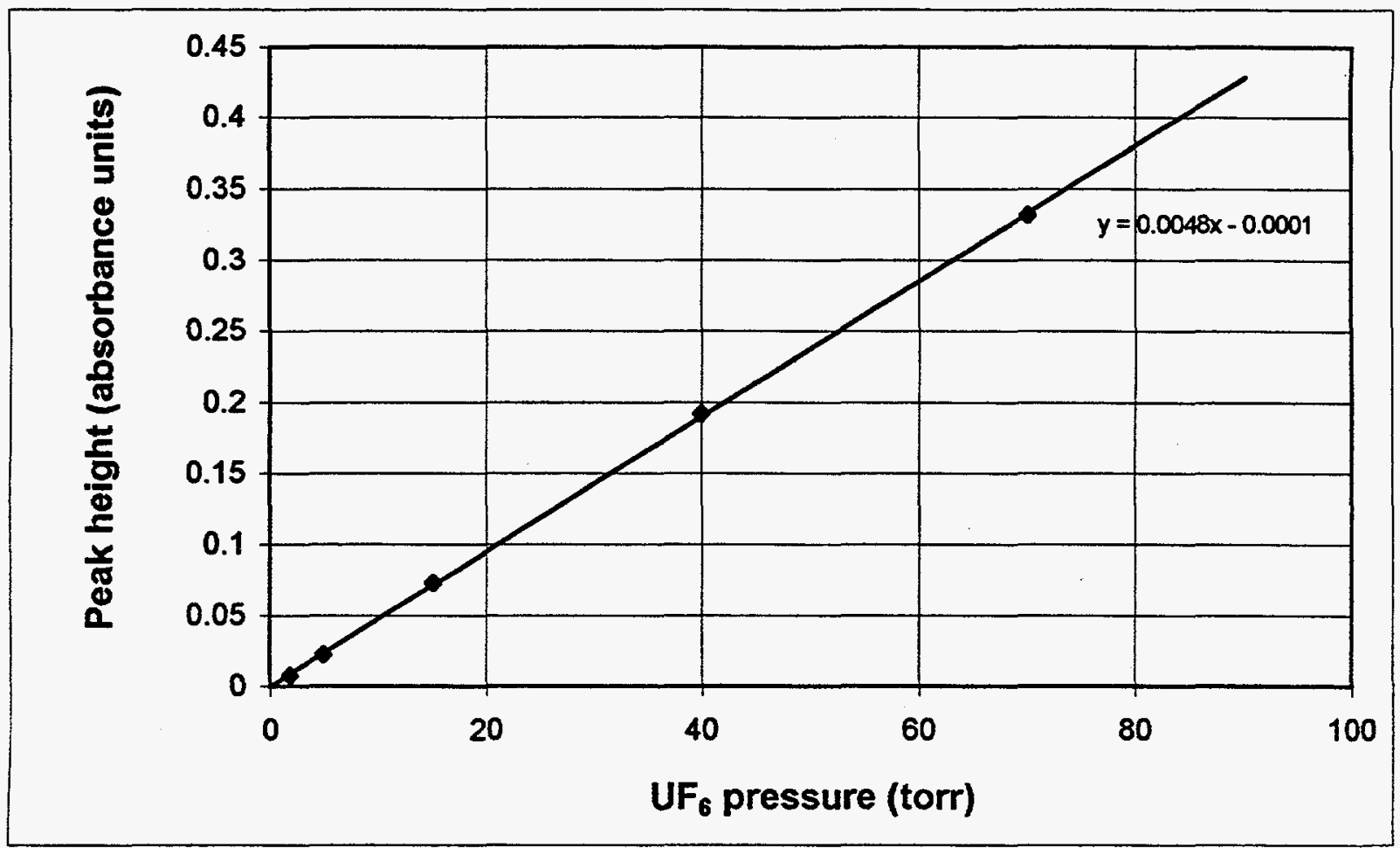

Fig. A-34. Peak height $\left(1157 \mathrm{~cm}^{-1}\right)$ vs UF $_{6}$ partial pressure in the $10-\mathrm{cm}$ IR cell.

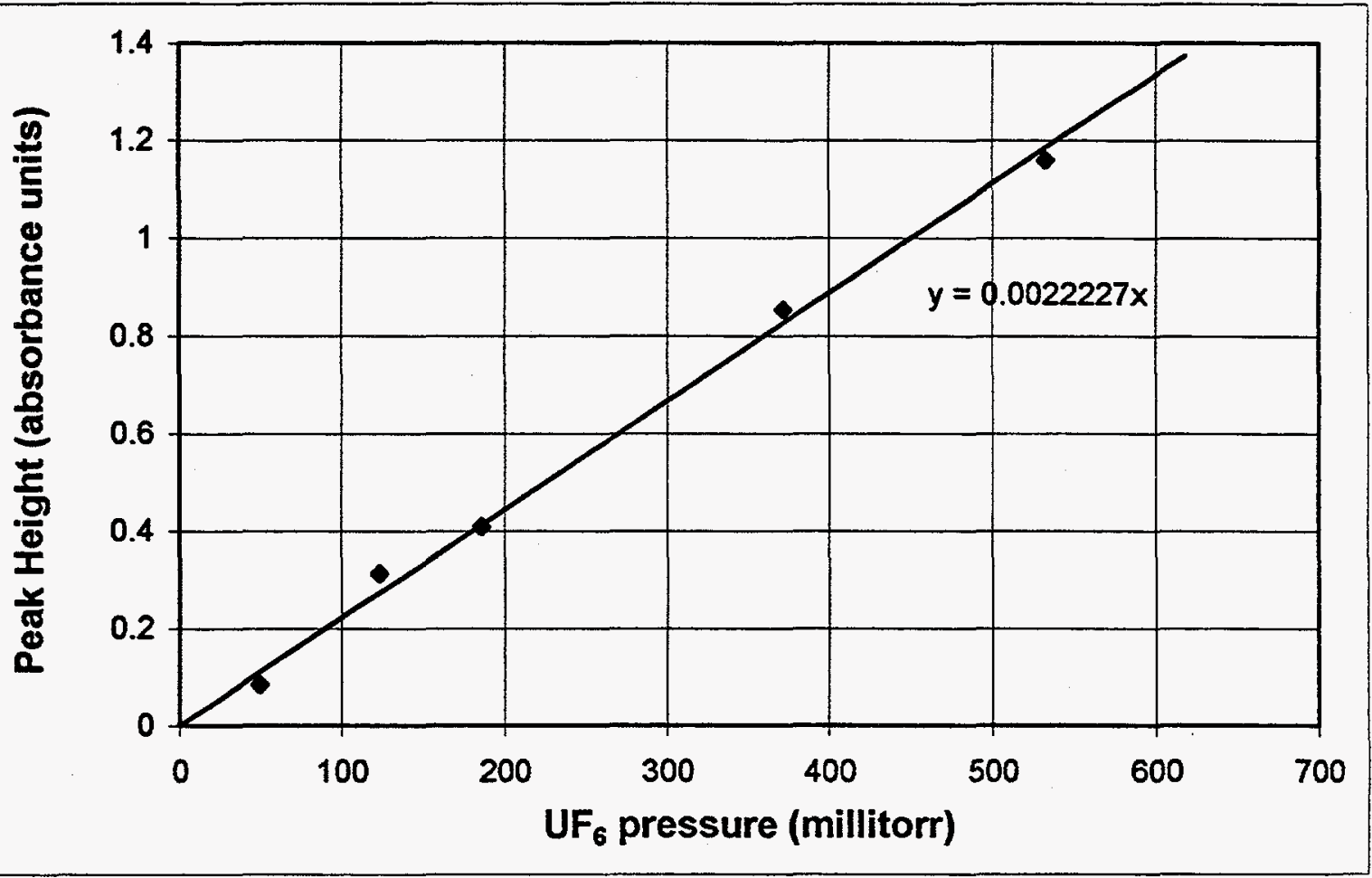

Fig. A-35. Peak height $\left(625 \mathrm{~cm}^{-1}\right)$ vs $U_{6}$ partial pressure in the $20-\mathrm{cm}$ IR cell. 


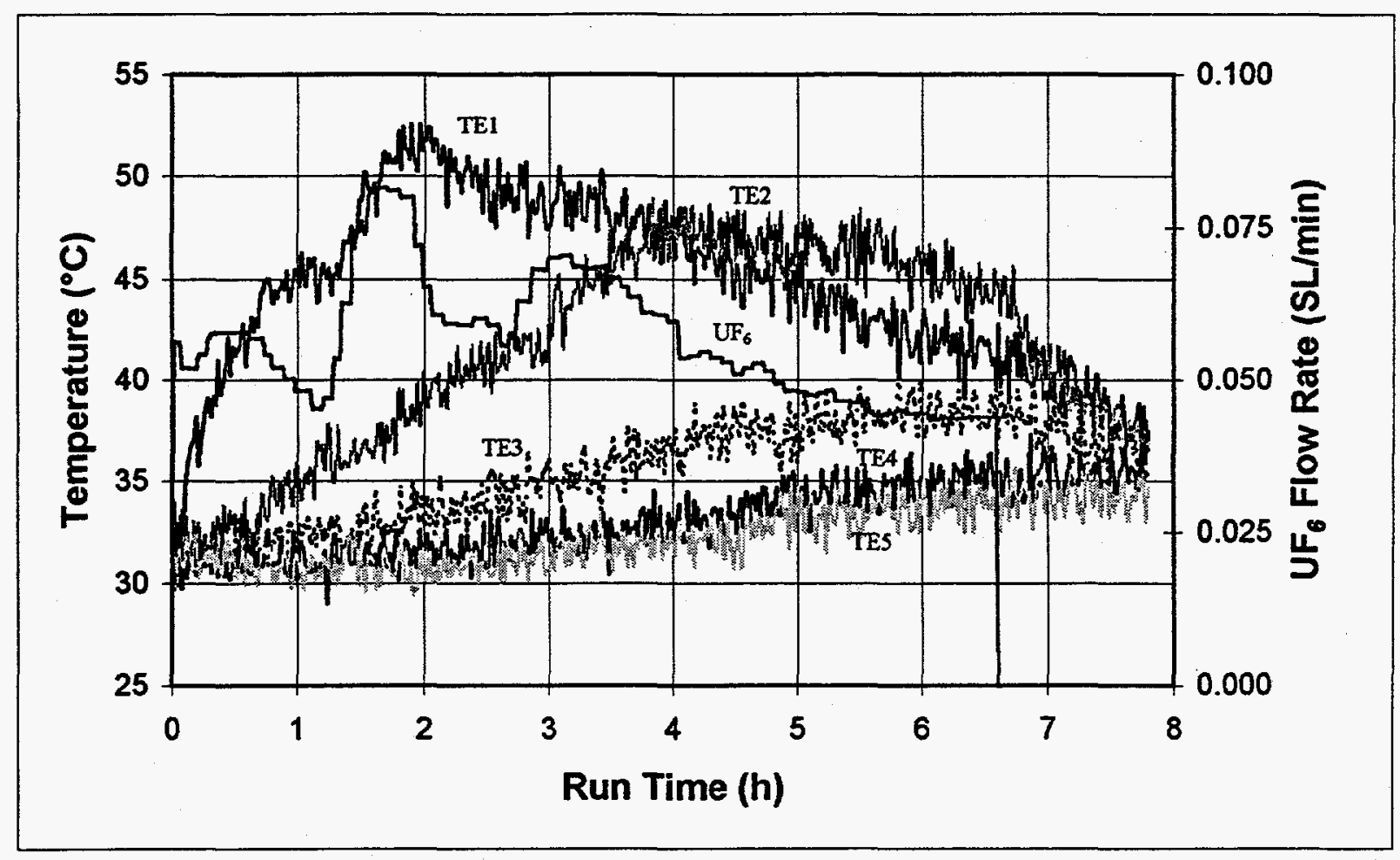

Fig. A-36. Sodium fluoride temperatures and $\mathrm{UF}_{6}$ flow rate, GBTP, March 25, 1996.

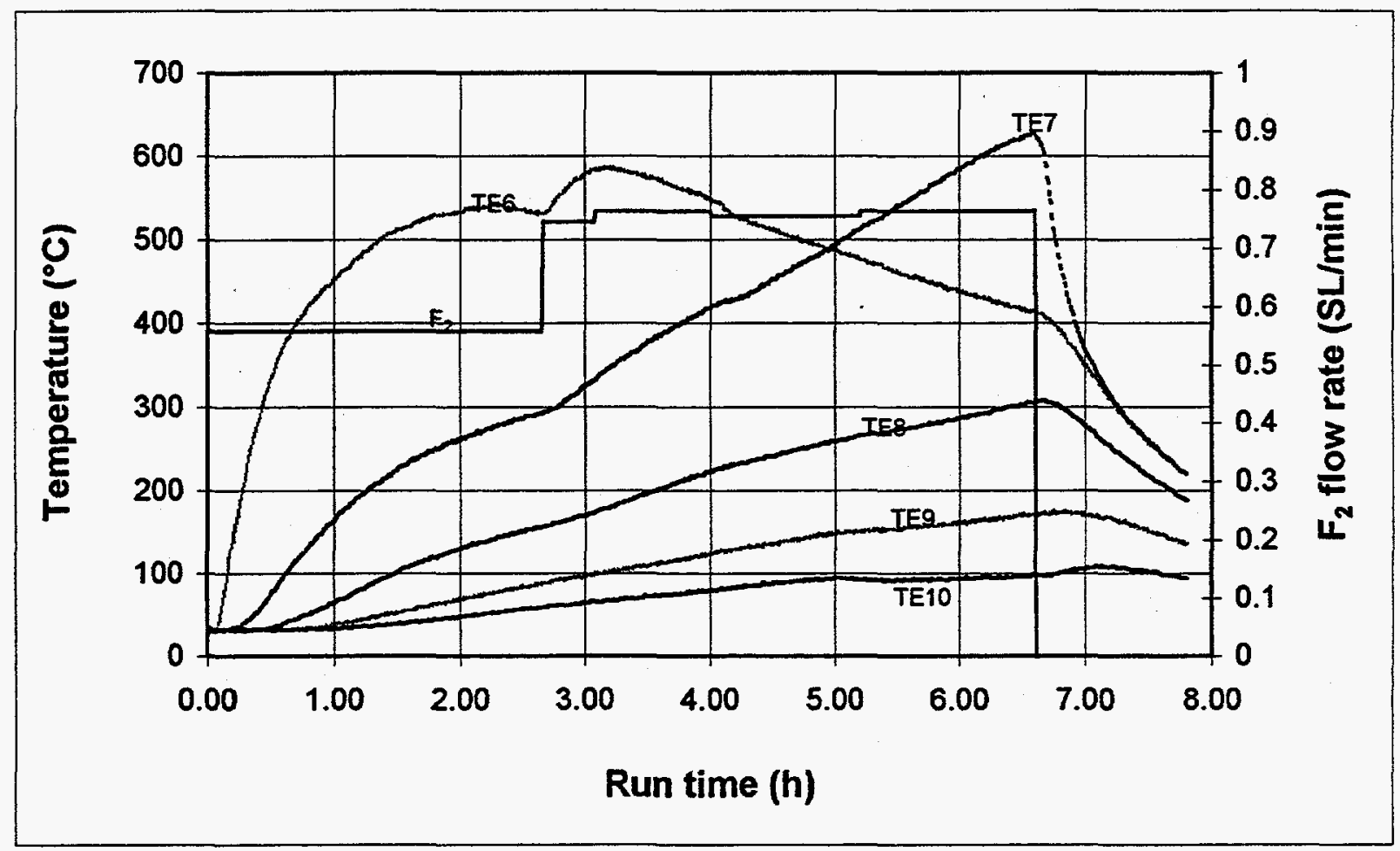

Fig. A-37. Alumina temperatures and $\mathrm{F}_{2}$ flow rate, GBTP, March 25, 1996. 


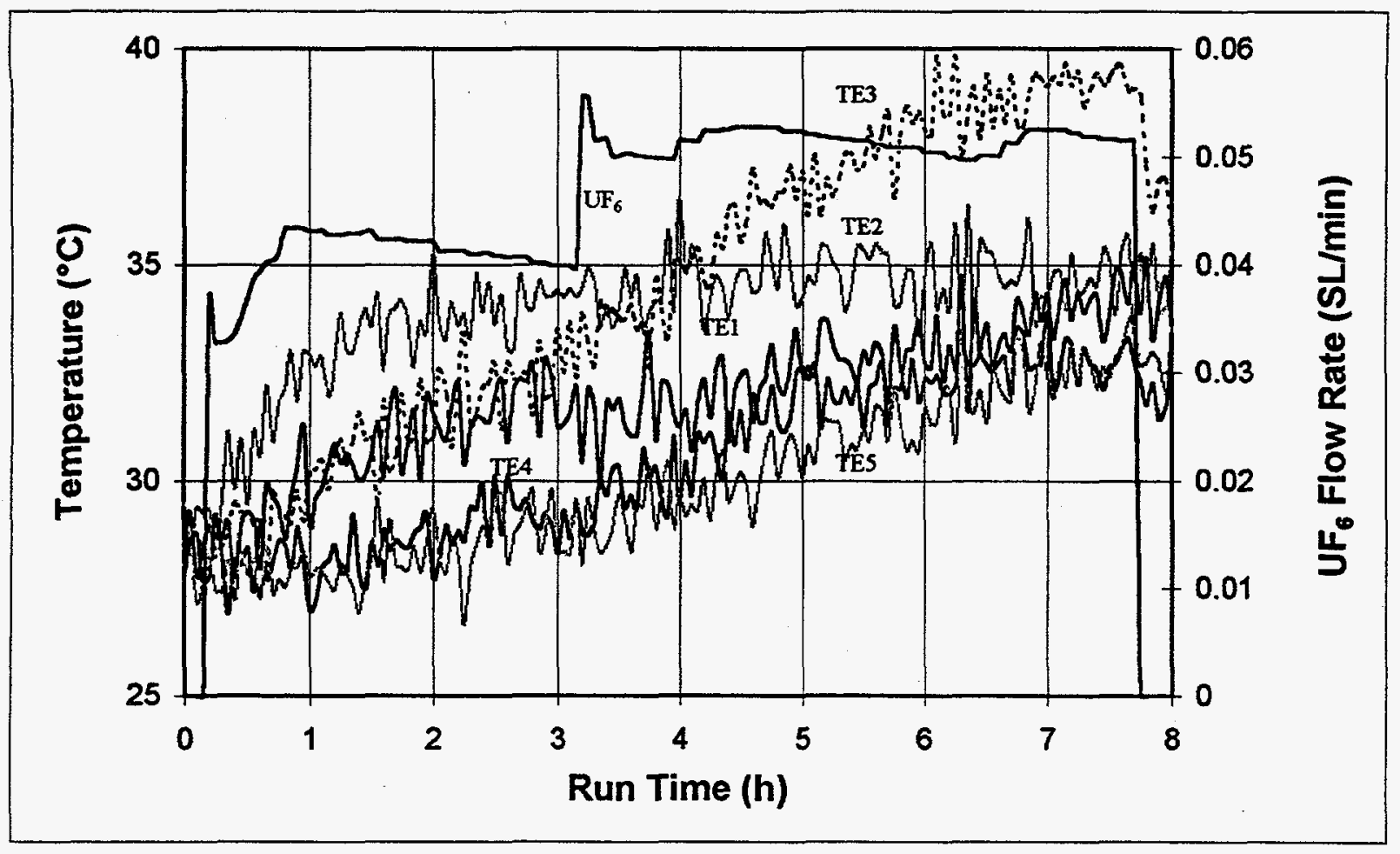

Fig. A-38. Sodium fluoride temperatures and $\mathrm{UF}_{6}$ flow rate, GBTP, March 26, 1996.

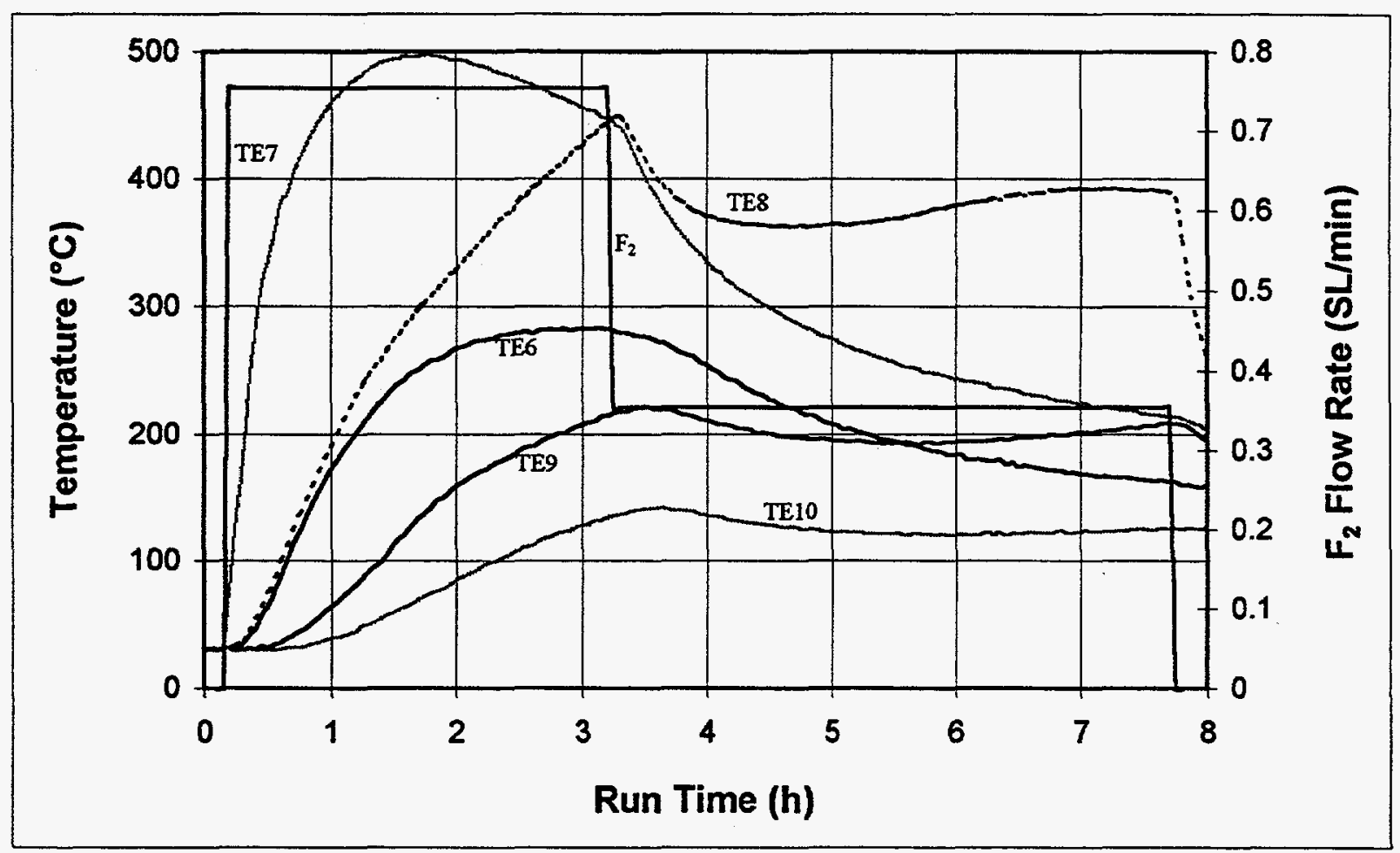

Fig. A-39. Alumina temperatures and $\mathrm{F}_{2}$ flow rate, GBTP, March 26, 1996. 


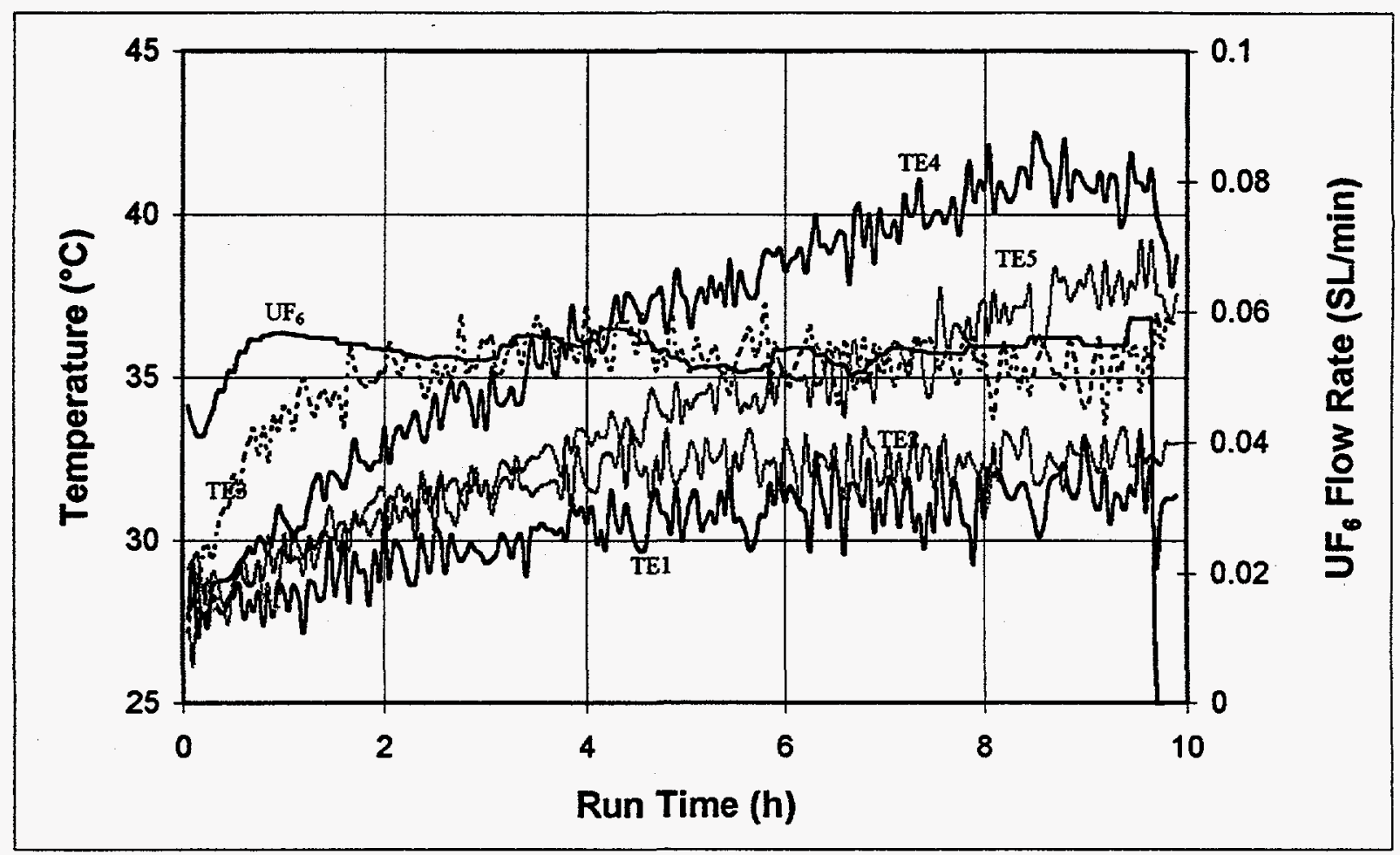

Fig. A-40. Sodium fluoride temperatures and $\mathrm{UF}_{6}$ flow rate, GBTP, March 27, 1996.

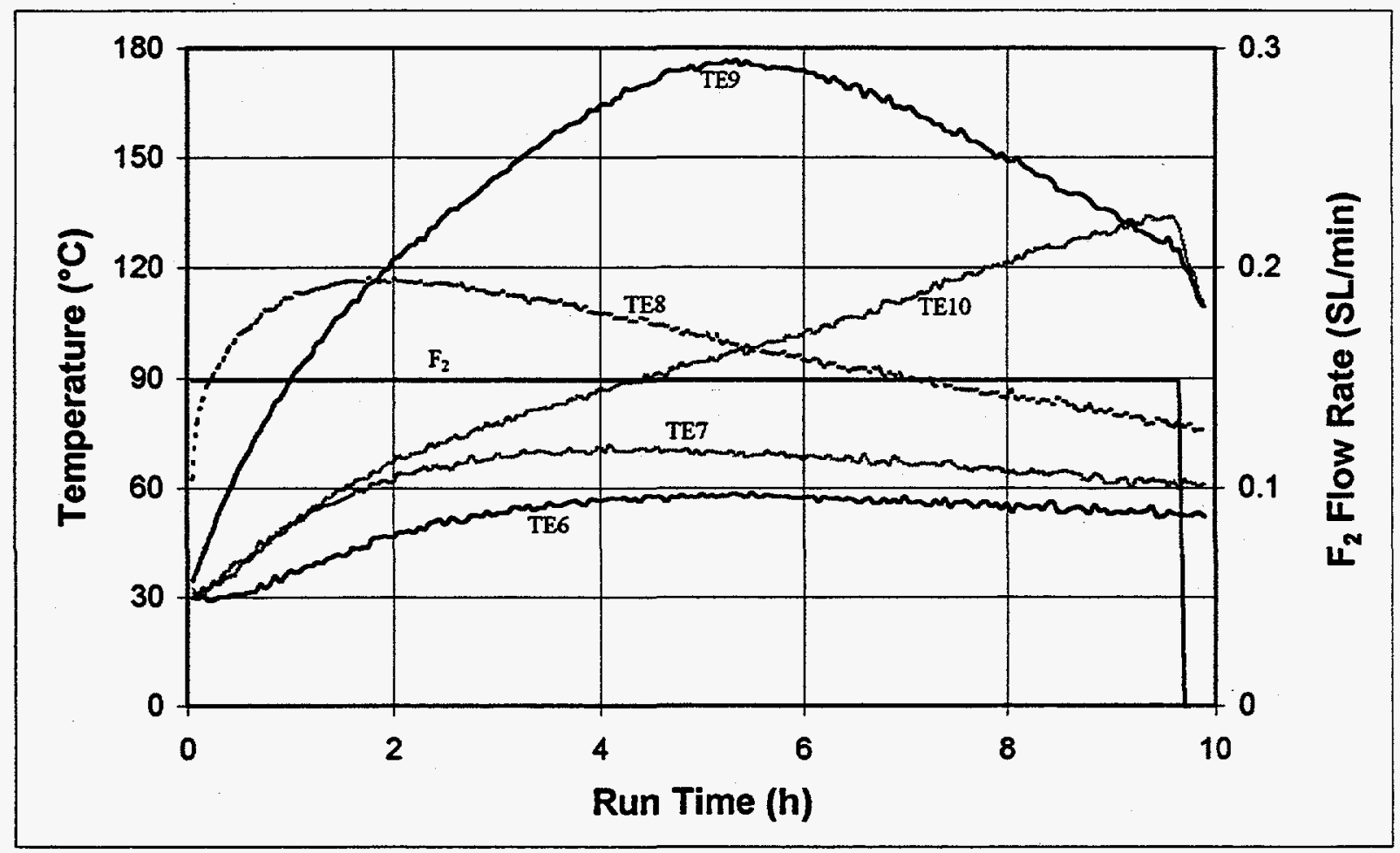

Fig. A-41. Alumina temperatures and $\mathrm{F}_{2}$ flow rate, GBTP, March 27, 1996. 


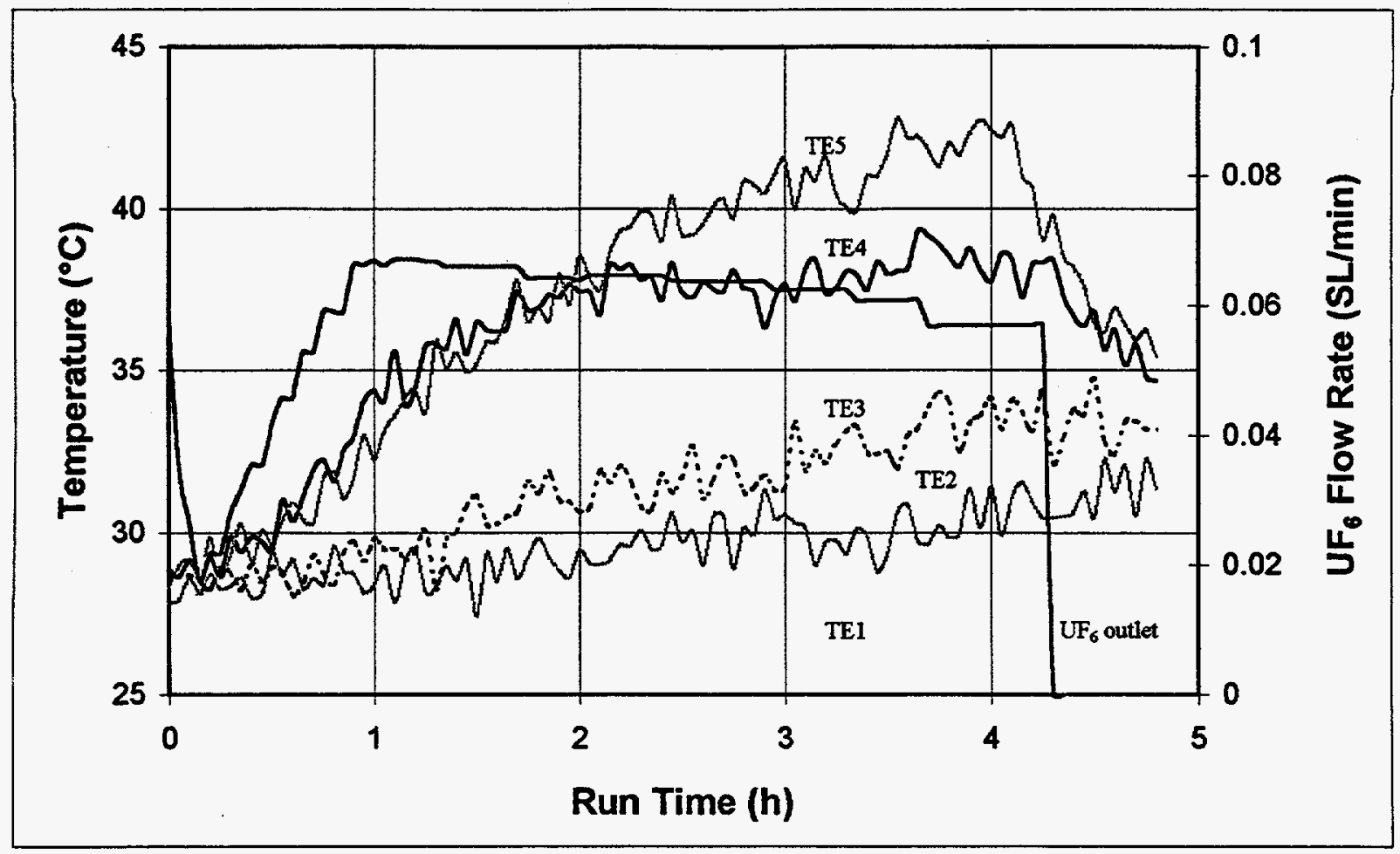

Fig. A-42. Sodium fluoride temperatures and $\mathrm{UF}_{6}$ flow rate, GBTP, March 28, 1996.

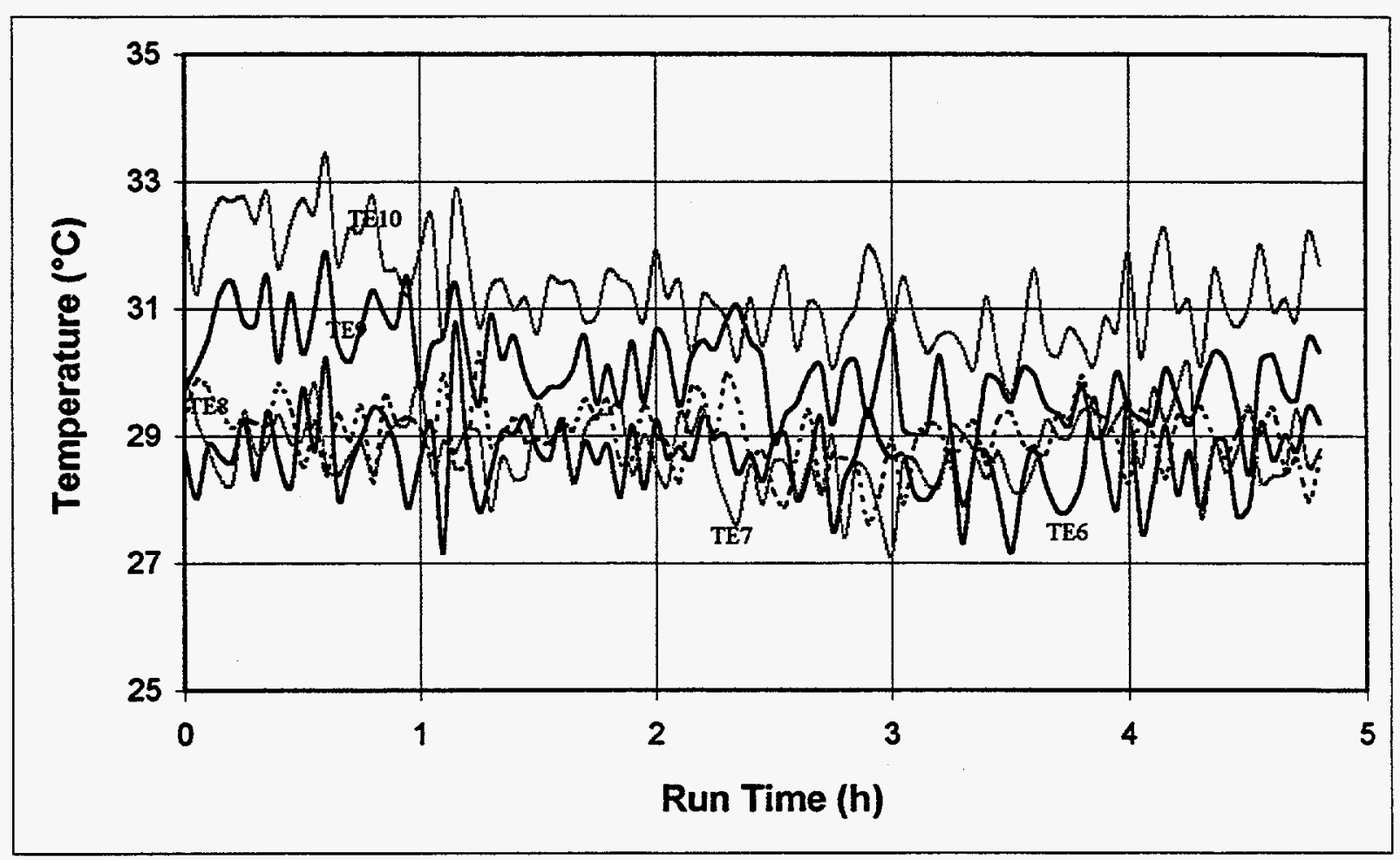

Fig. A-43. Alumina temperatures, no $F_{2}$ flow, GBTP, March 28, 1996. 


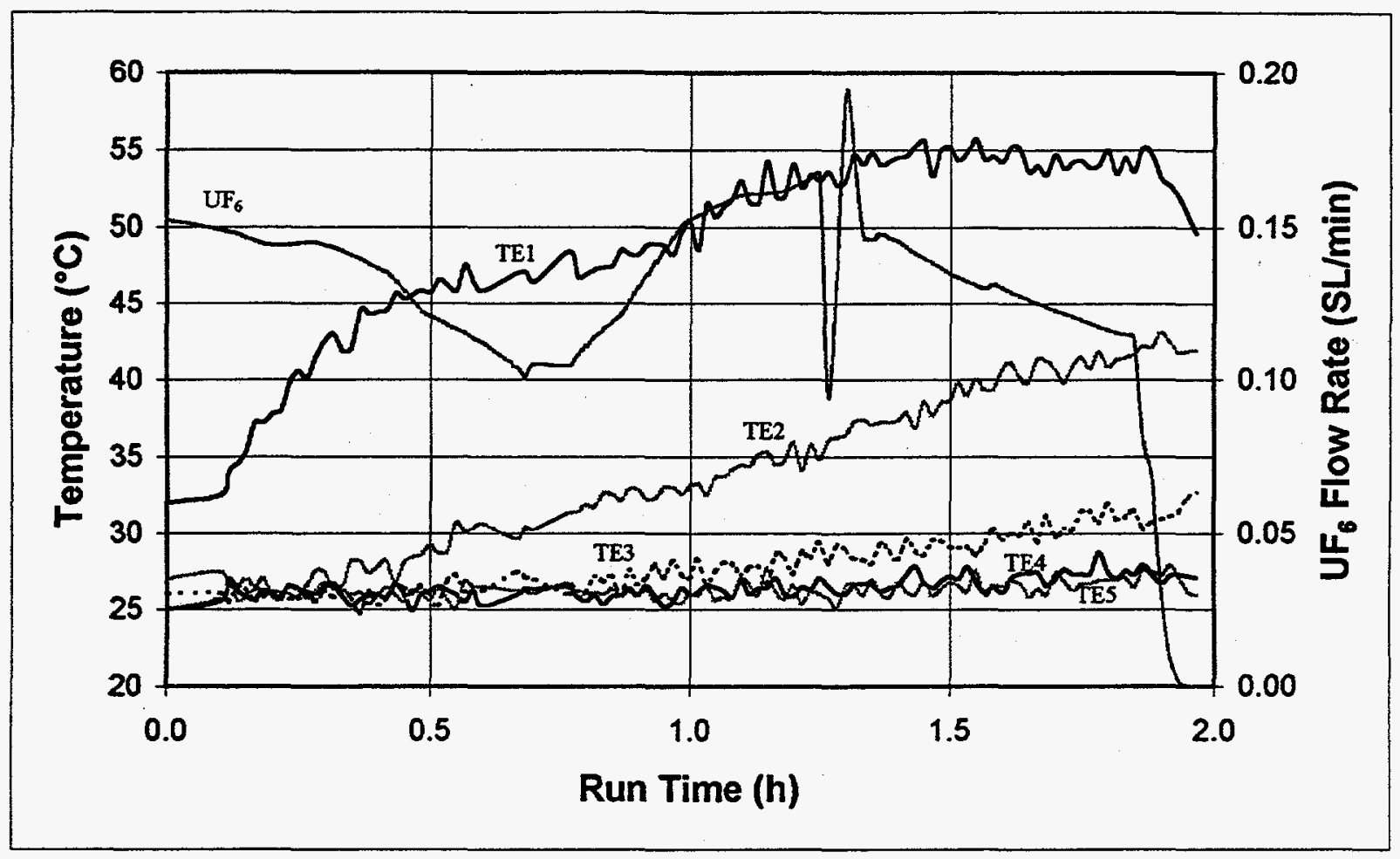

Fig. A-44. Sodium fluoride temperatures and $\mathrm{UF}_{6}$ flow rate, GBTV-1, April 9, 1996.

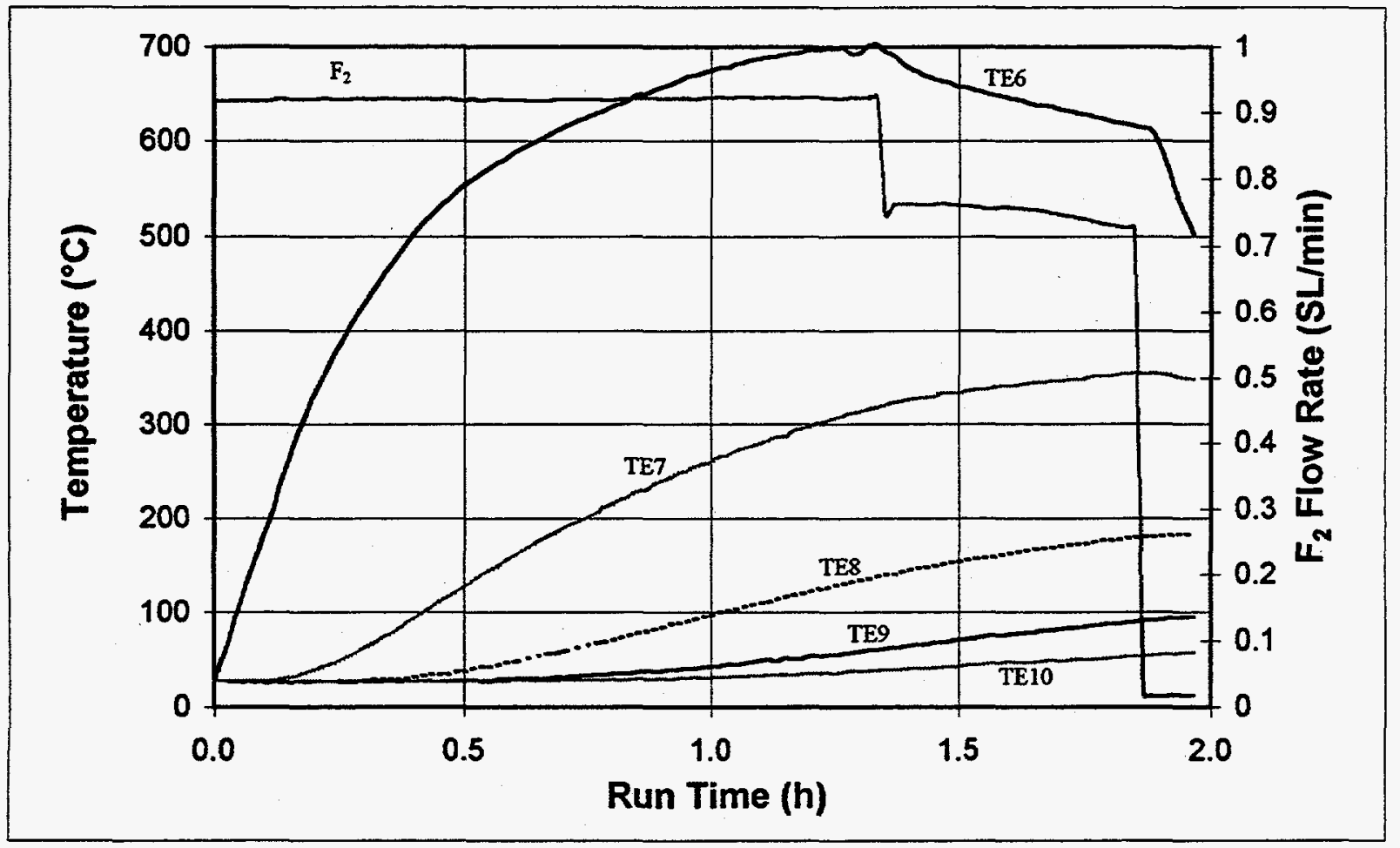

Fig. A-45. Alumina temperatures and $F_{2}$ flow rate, GBTV-1, April 9, 1996. 


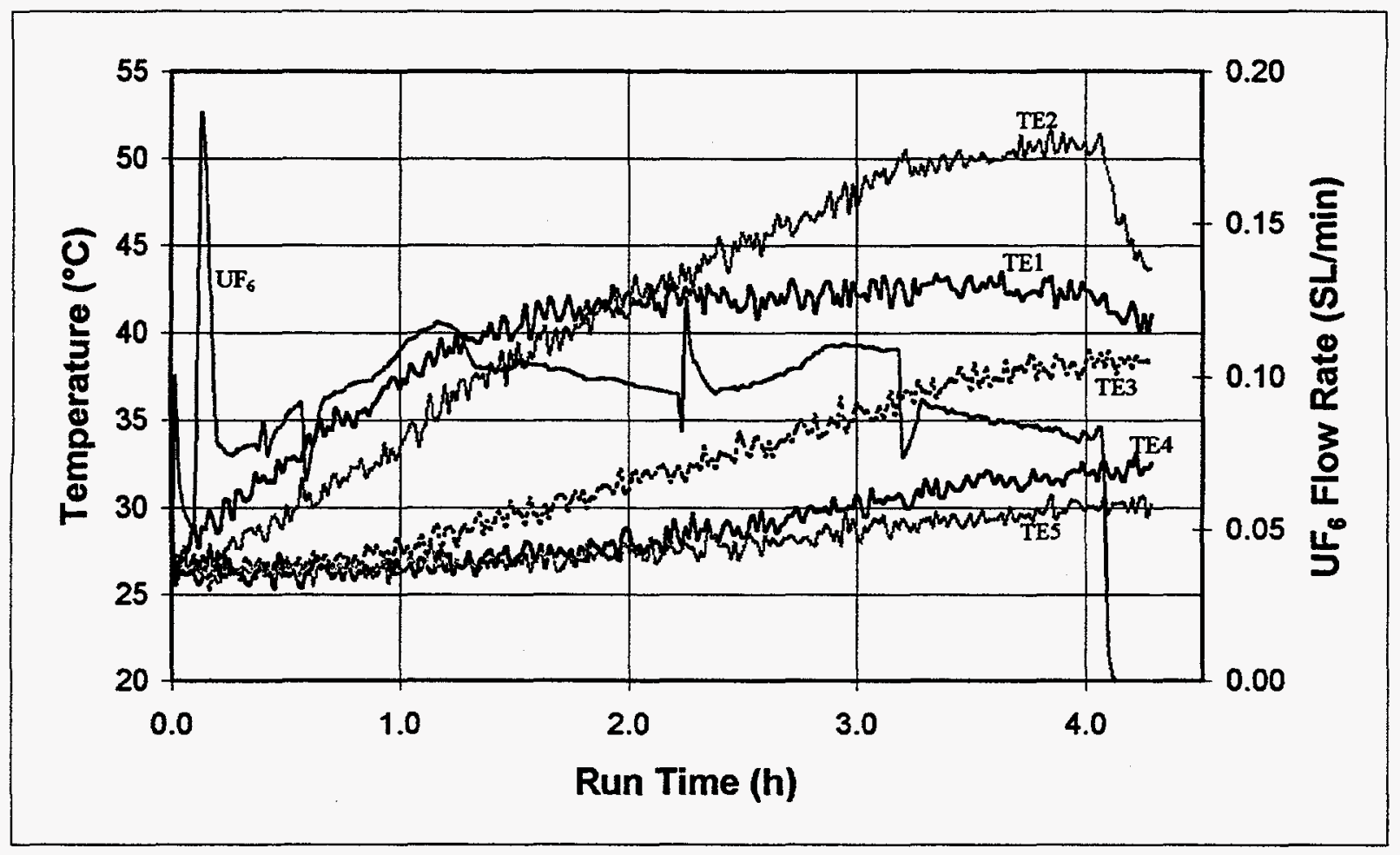

Fig. A-46. Sodium fluoride temperatures and $\mathrm{UF}_{6}$ flow rate, GBTV-2, April 10, 1996.

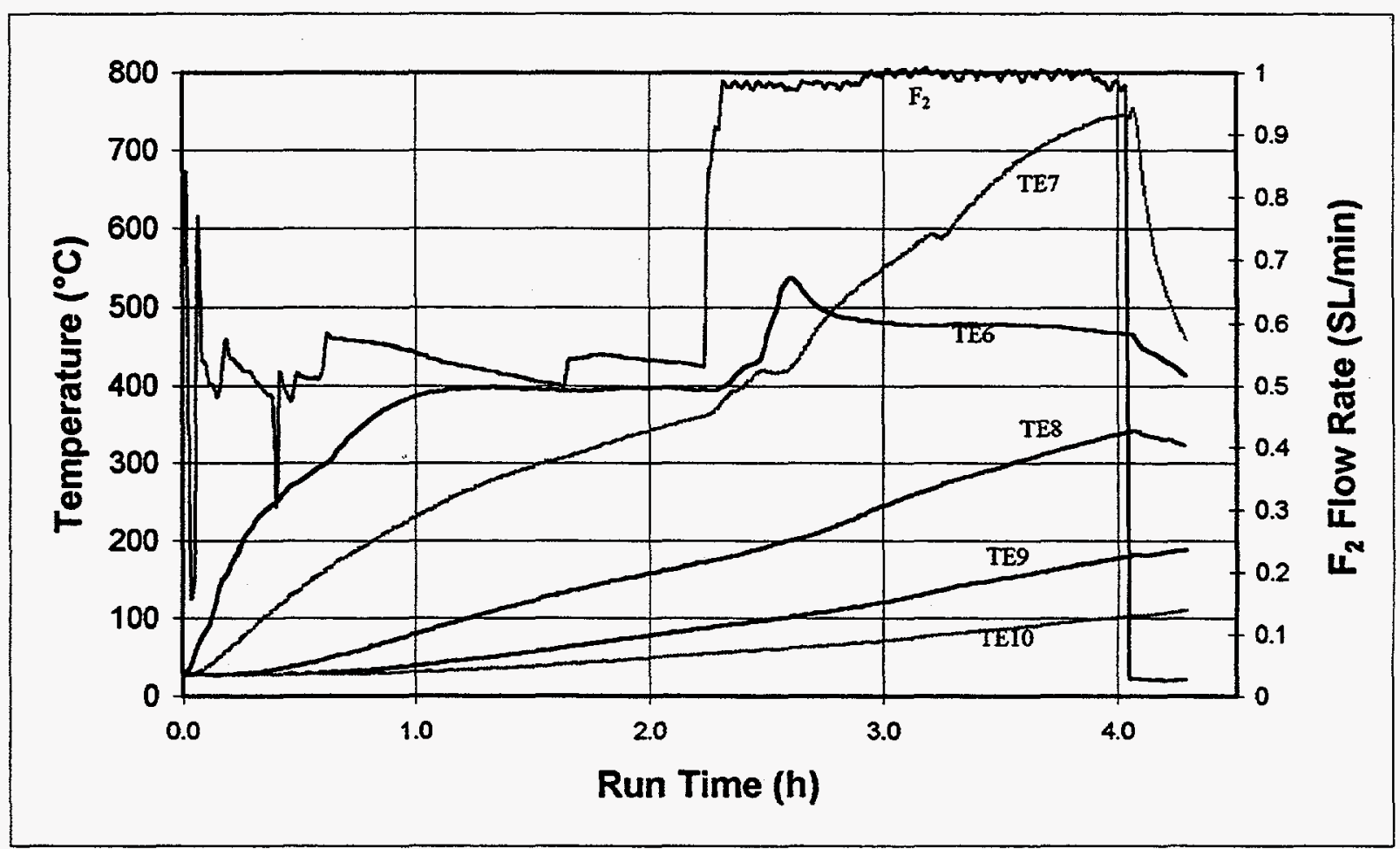

Fig. A-47. Alumina temperatures and $\mathrm{F}_{2}$ flow rate, GBTV-2, April 10, 1996. 


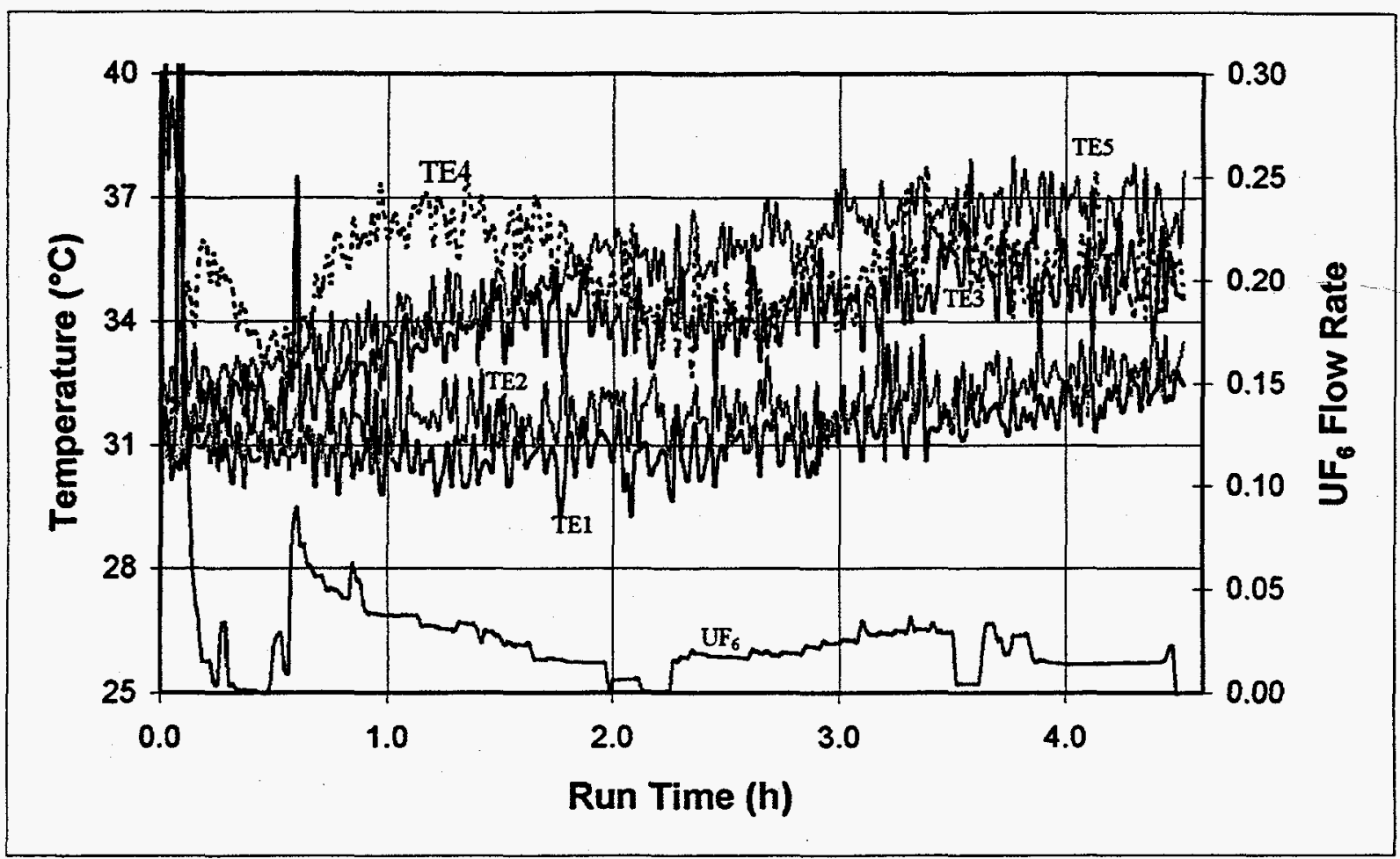

Fig. A-48. Sodium fluoride temperatures and $\mathrm{UF}_{6}$ flow rate, GBTV-4, April 12, 1996.

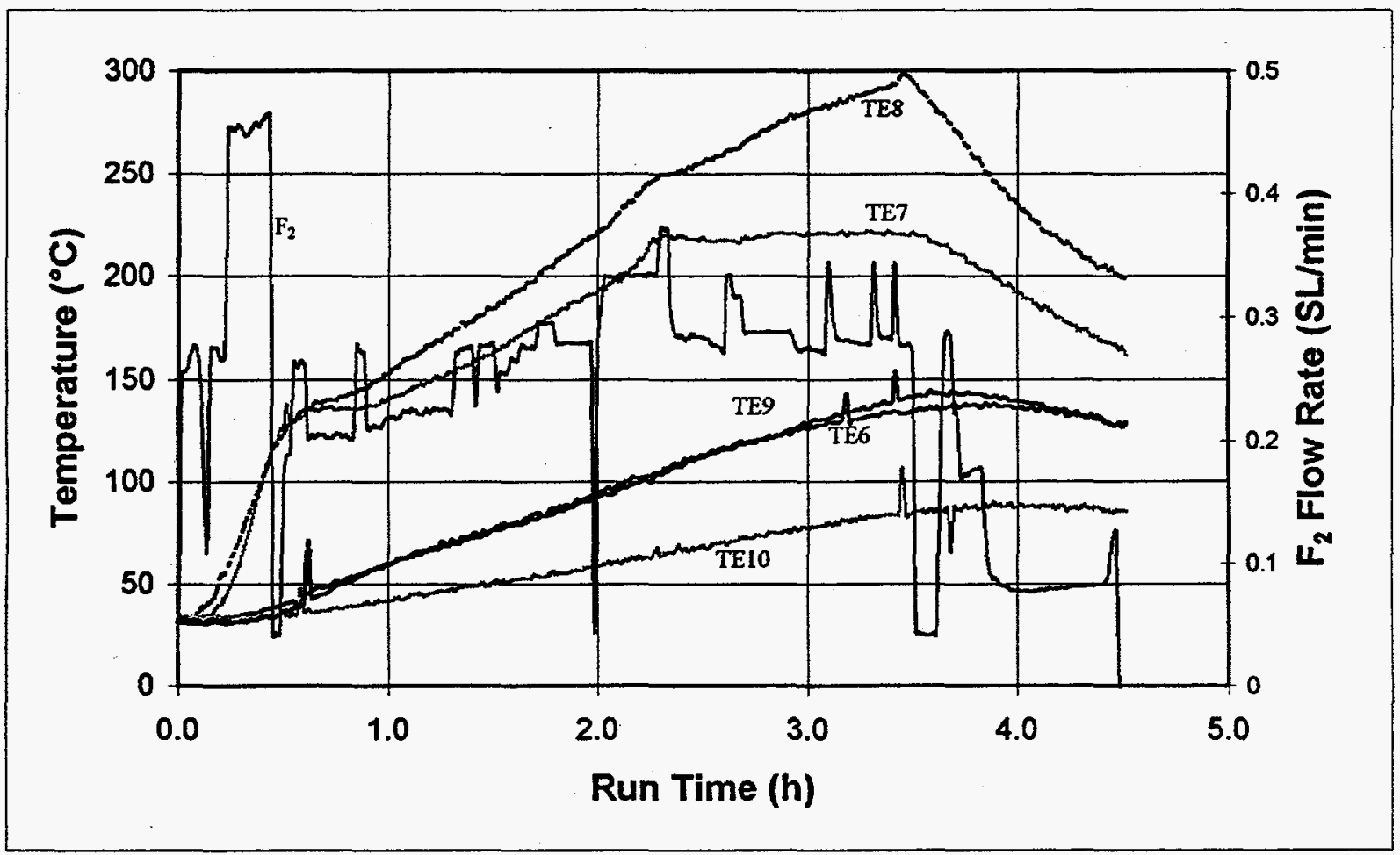

Fig. A-49. Alumina temperatures and $\mathrm{F}_{2}$ flow rate, GBTV-4, April 12, 1996. 


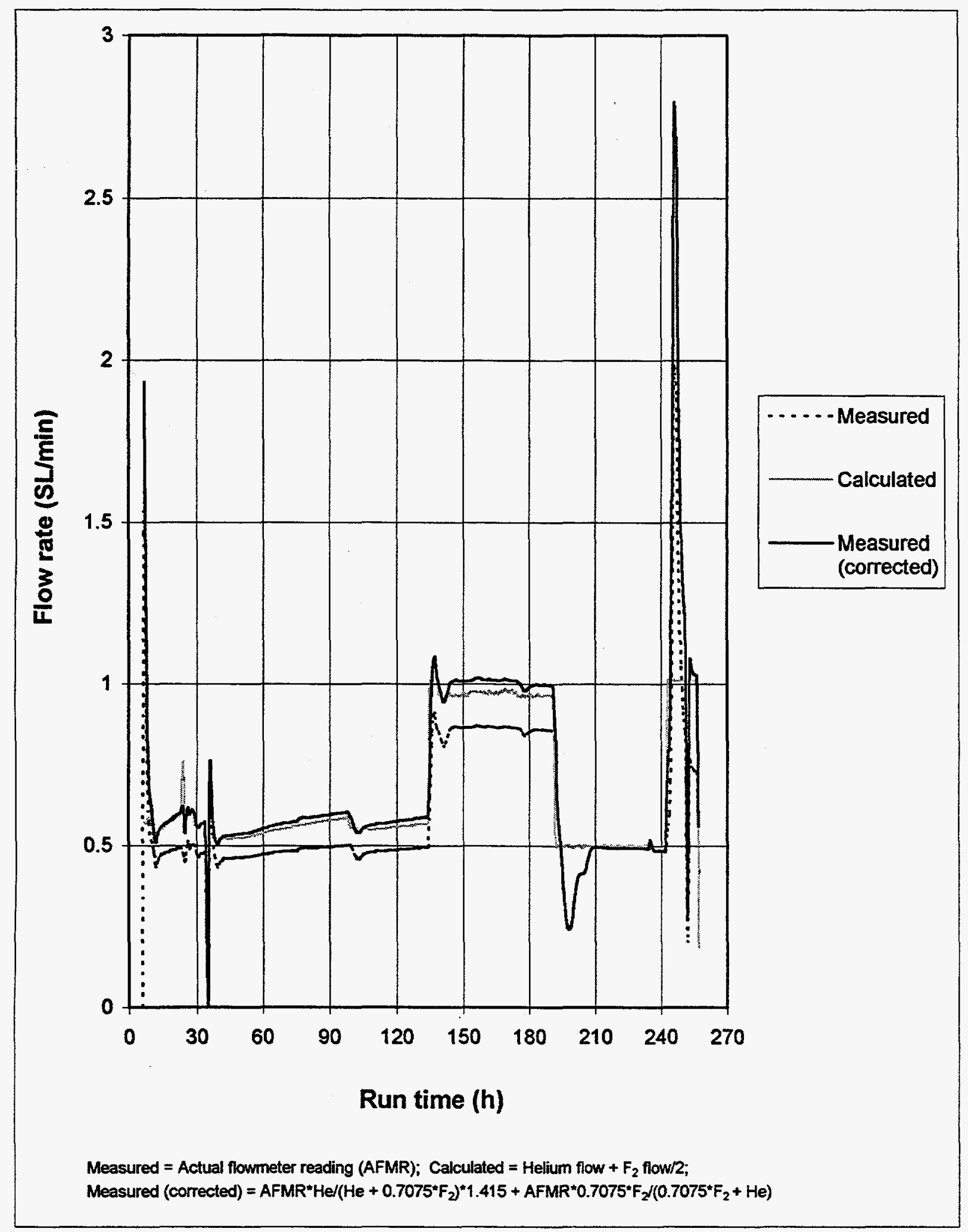

Fig. A-50. Exit flow measurements, GBTV-2, April 10, 1996. 


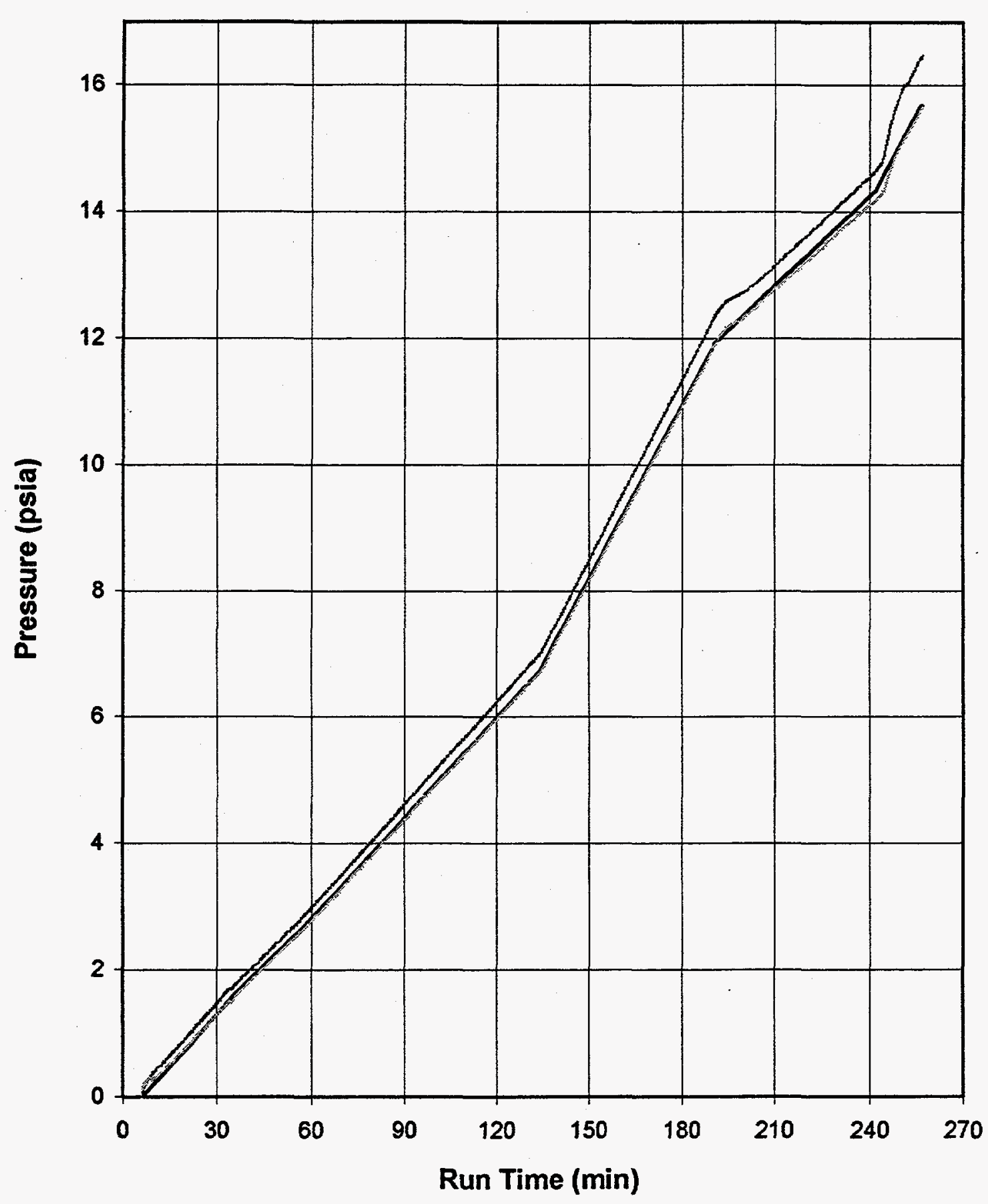

Calculated flow tank pressure

Measured flow tank pressure Measured tank pressure

Fig. A-51. Tank pressure rise, GBTV-2, April 10, 1996. 


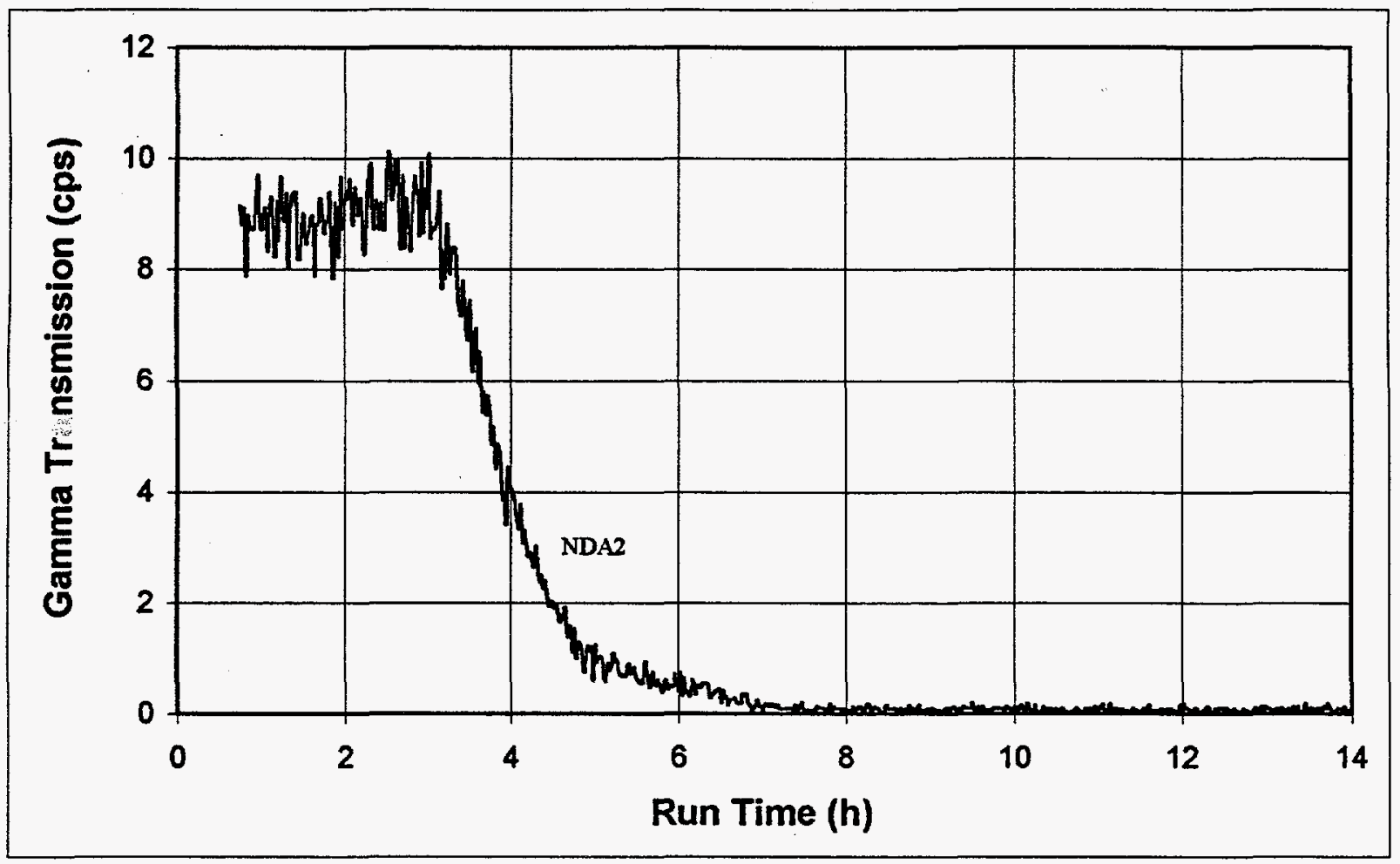

Fig. A-52. Gamma transmission received by second NDA detector throughout GBTV. 
Appendix B

DETERMINATION OF FLUORINE LOADING PER GRAM INCREASE OF TRAP WEIGHT 



\section{Appendix B. DETERMINATION OF FLUORINE LOADING \\ PER GRAM INCREASE OF TRAP WEIGHT}

The stoichiometric reaction for $\mathrm{F}_{2}$ and $\mathrm{Al}_{2} \mathrm{O}_{3}$ is

$$
\frac{1}{3} A l_{2} O_{3}+F_{2}=\frac{2}{3} A l F_{3}+\frac{1}{2} O_{2} .
$$

The molecular weights for the compounds are

$\mathrm{AlF}_{3}, 83.977 \mathrm{~g} / \mathrm{mol}$;

$\mathrm{Al}_{2} \mathrm{O}_{3}, 101.661 \mathrm{~g} / \mathrm{mol}$;

$\mathrm{F}_{2}, 39.997 \mathrm{~g} / \mathrm{mol}$; and

$\mathrm{O}_{2}, 31.999 \mathrm{~g} / \mathrm{mol}$.

Therefore, the weight change per mole of fluorine added is

$2 / 3 * 83.977-1 / 3 * 101.661=22.098 \mathrm{~g} / \mathrm{mol} \mathrm{F}_{2}$.

Assuming an ideal gas:

$22.4147 \mathrm{~L} \mathrm{~F}_{2} / \mathrm{mol} \mathrm{F}_{2}$

Therefore:

$22.4147 \mathrm{~L} \mathrm{~F}_{2} / \mathrm{mol} \mathrm{F}_{2} / 22.098 \mathrm{~g} / \mathrm{mol} \mathrm{F}_{2}=1.014 \mathrm{~L} \mathrm{~F}_{2}$ trapped per gram of weight increase. 
Appendix C

CALCULATION OF FLUORINE FLOW RATE BASED ON EXIT FLOWMETER READING AND HOLDING TANK PRESSURE RISE 



\section{Appendix C. CALCULATION OF FLUORINE FLOW RATE BASED ON EXIT FLOWMETER READING AND HOLDING TANK PRESSURE RISE}

The exit flowmeter can be used to determine the fluorine flow rate because the variation in thermal conductivities of different gases causes different correction factors to be applied for these gases. This means that if there are only two main constituent gases with significantly different correction factors, the molar composition of the gas can be determined from one indicated flow rate. This is the case with gas (usually helium and oxygen) entering the holding tank.

The fluorine flow rate can be determined from the following equation:

$$
n=\frac{P 1 * V 1}{R * T 1}
$$

where $P I=$ holding tank pressure, $T I=$ tank pressure, $V I=$ tank volume, $\mathrm{R}=$ gas constant, and $n=$ moles of gas.

The value of $V I$ is known, and $P 1$ and $T 1$ are continuously measured. By taking pressure and temperature measurements over time, a molar flow rate $n^{\prime}$ can be determined. From $n^{\prime}$,

$$
V 1^{\prime}=\frac{n^{\prime} * R * T 2}{P 2},
$$

where $T 2=$ standard temperature $(273.15 \mathrm{~K}) ; P 2=$ standard pressure $(1 \mathrm{~atm})$; and $V 1^{\prime}=$ gas flow rate. Using the manufacturer-specified conversions for helium and oxygen as compared with those for fluorine $\left(1.520 \mathrm{He} / \mathrm{F}_{2}, 1.074 \mathrm{O}_{2} / \mathrm{F}_{2}\right)$ and the total flow volume calculated above, the problem reduces to two equations and two unknowns:

$$
\begin{gathered}
\frac{H e^{\prime}}{1.52}+\frac{\mathrm{O}_{2}{ }^{\prime}}{1.074}=V 2^{\prime} \\
\mathrm{He}^{\prime}+\mathrm{O}_{2}^{\prime}=V 1^{\prime}
\end{gathered}
$$

where $H e^{\prime}=$ helium flow rate, $\mathrm{O}_{2}{ }^{\prime}=$ oxygen flow rate, and $V 2^{\prime}=$ indicated flow rate on exit flowmeter.

Solving these equations gives the oxygen and helium flow rates. The fluorine flow rate is equal to twice the oxygen flow rate (see Appendix B). 


\section{INTERNAL DISTRIBUTION}

1. R. R. Aigner

2. J. F. Alexander

3. D. P. Armstrong

4. C. E. Bamberger

5. W. D. Brickeen

6. M. E. Buchanan

7. S. N. Burman

8. W. A. Camp

9. R. A. Campbell

10. O. E. Clark

11. S. G. Coffey

12. A. G. Croff

13. S. Dai

14-17. G. D. Del Cul

18. J. R. DeVore

19. J. R. DiStefano

20. R. L. Faulkner

21. U. Gat

22. L. L. Gilpin

23. Q. G. Grindstaff

24. E. C. Hickman

25. J. S. Ivey

26. P. S. Johnson

27. R. T. Jubin

28. J. R. Keiser
29. R. A. Kite

30. S. L. Loghry

31. L. E. McNeese

32. T. C. Morelock

33. S. H. Park

34. B. D. Patton

35. S. J. Pawel

36. F. J. Peretz

37. D. W. Ramey

38-42. J. C. Rudolph

43-46. J. E. Rushton

47. D. W. Simmons

48. N. R. Smyrl

49. R. M. Szozda

50-54. L. M. Toth

55. L. D. Trowbridge

56. K. L. Walker

57. D. F. Williams

58. ER Document Management Center

59. Central Research Library

60. ORNL Laboratory Records-RC

61-62. ORNL Laboratory Records for OSTI

\section{EXTERNAL DISTRIBUTION}

63. J. Caja, 9052 Highbridge Drive, Knoxville, TN 37922

64. J. H. DeVan, 107 Orange Lane, Oak Ridge, TN 37830

65. J. R. Engel, 118 E. Morningside Drive, Oak Ridge, TN 37830

66. P. A. Haas, 1205 Chickering Way, Knoxville, TN 37923

67. G. R. Hudson, Project Management Division, Department of Energy, Oak Ridge Operations, P. O. Box 2001, Oak Ridge, TN 37831

68. R. L. Jones, Paducah Gaseous Diffusion Plant, Bldg. C300, P. O. Box 1410, Paducah, KY 42002-1410

69. M. R. Jugan, Environmental Restoration, Department of Energy, Oak Ridge Operations, P. O. Box 2001, Oak Ridge, TN 37831

70. J. J. Laidler, Director, Chemical Technology Division, Argonne National Laboratory, 9700 S. Cass Avenue - Bldg. 205, Argonne, IL 60439 
71. N. W. Lingle, Environmental Restoration, Department of Energy, Oak Ridge Operations, P. O. Box 2001, Oak Ridge, TN 37831

72. D. W. Neiswander, 9317 Norlake Circle, Knoxville, TN 37922

73. K. J. Notz, Henley Point-River Road, Kingston, TN 37763

74. A. L. Olson, Idaho National Engineering Laboratory, P. O. Box 1625, MS-5219, Idaho Falls, ID 83415-5219

75. L. P. Pugh, 2024 Cedar Lane, Kingston, TN 37763

76. R. G. Russell, Paducah Gaseous Diffusion Plant, Bldg. C710, P. O. Box 1410, Paducah, KY 42002-1410

77. A. J. Saraceno, Portsmouth Gaseous Diffusion Plant, Bldg. X710, P. O. Box 628, MS-2212, Portsmouth, OH 45661-2212

78. J. E. Shoemaker, Jr., Portsmouth Gaseous Diffusion Plant, Bldg. X100, P. O. Box 628, MS-1223, Portsmouth, OH 45661-1223

79. R. E. Thoma, 119 Underwood Road, Oak Ridge, TN 37830

80. P. G. Wooldridge, Paducah Gaseous Diffusion Plant, Bldg. C710, P. O. Box 1410, Paducah, KY 42002-1410

81. R. G. Wymer, 188-A Outer Drive, Oak Ridge, TN 37830

82. E. L. Youngblood, 198 N. Purdue Avenue, Oak Ridge, TN 37830 